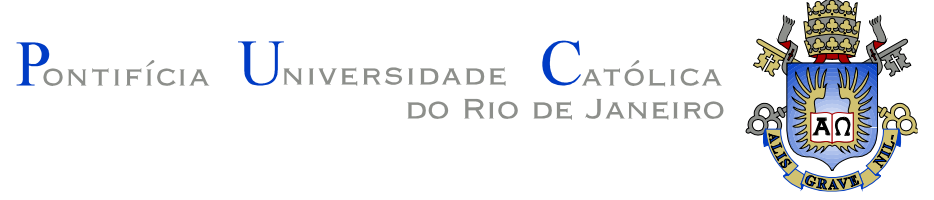

Jimmy Llontop Incio

Estudos espectroscópicos de fluorquinolonas e seus complexos de cobre(II): interação com micelas, lipossomas e nanocompósitos de ouro

Tese de Doutorado

Tese apresentada como requisito parcial para obtenção do grau de Doutor pelo Programa de PósGraduação em Física da PUC-Rio.

Orientador: Profa. Sônia Renaux Wanderley Louro

Rio de Janeiro

Agosto de 2018 


\section{Estudos espectroscópicos de fluorquinolonas e seus complexos de cobre(II): interação com micelas, lipossomas e nanocompósitos de ouro}

Tese apresentada como requisito parcial para obtenção do grau de Doutor pelo Programa de Pós-Graduação em Física do Departamento de Física do Centro Técnico Científico da PUC-Rio. Aprovada pela Comissão Examinadora abaixo assinada.

Profa. Sônia Renaux Wanderley Louro Orientadora Departamento de Física - PUC-Rio

Profa. Letícia Regina de Souza Teixeira UFMG

Prof. Odivaldo Cambraia Alves UFF

Profa. Aurora Pérez Gramatges Departamento de Química - PUC-Rio

Prof. Jefferson Ferraz Damasceno Felix Araujo Departamento de Física - PUC-Rio

Prof. Márcio da Silveira Carvalho Coordenador Setorial do Centro Técnico Científico - PUC-Rio 
Todos os direitos reservados. É proibida a reprodução total ou parcial do trabalho sem autorização da universidade, do autor e dos orientadores.

\section{Jimmy Llontop Incio}

Graduou-se em Física na UNI (Universidad Nacional de Ingenieria - Lima - Perú) em 2011. Fez mestrado no Departamento de Física da Pontifícia Universidade Católica do Rio de Janeiro - Rio em 2014.

Ficha Catalográfica

Incio, Jimmy Llontop

Estudos espectroscópicos de fluorquinolonas e seus complexos de cobre(II): interação com micelas, lipossomas e nanocompósitos de ouro / Jimmy Llontop Incio; orientadora: Sônia Renaux Wanderley Louro. - Rio de Janeiro, PUC-Rio, Departamento de Física, 2018.

120 f.: il. color. ; $30 \mathrm{~cm}$

Tese (Doutorado) - Pontifícia Universidade Católica do Rio de Janeiro, Departamento de Física, 2018.

Inclui referências bibliográficas.

1. Complexos de cobre - Teses. 2. Fluorquinolonas. 3. Norfloxacina. 4. Micelas. 5. Lipossomas. 6. Nanopartículas de ouro. 7. Ablação a laser. I. Louro, Sônia R. W. II. Pontifícia Universidade Católica do Rio de Janeiro. Departamento de Física. III. Título.

CDD: 530 
Dedico a:

Minha mãe Maria Esther Incio e ao meu pai Pedro Llontop, que têm sido a fonte de minha inspiração, de meu esforço e dedicação.

A minha família: irmãos e cunhado, por estar sempre comigo, incondicionalmente, apoiando-me moralmente e acreditando sempre em mim. 


\section{Agradecimentos}

A Deus, por me amparar sempre nos momentos difíceis, por me dar a força suficiente para vencer todas as dificuldades a serem apresentadas, por me mostrar o caminho nas horas incertas e por me suprir em todas minhas necessidades.

Aos meus pais, Pedro Llontop Gonzales e Maria Esther Incio Puyen, pela minha vida, compreensão, esforço, apoio constante, e aos meus irmãos Elvis e Noelia pela ajuda nos momentos que eu precisei, muito agradecido a minha família.

À minha orientadora, a Professora Sônia Renaux Wanderley Louro, por sua dedicação, ensinamentos e paciência infinita. Sem ela este trabalho não teria sido realizado.

Ao professor Tommaso Del Rosso, do Departamento de Física da PUC-Rio, pela síntese e disponibilização dos nanocompósitos de ouro.

Aos meus amigos, em especial meus colegas de laboratório, por me ajudar em todo o trajeto do meu doutorado, sempre me ajudando dentro do laboratório e mediante conhecimentos científicos. A todos os professores da Física pelos conhecimentos recebidos e pela acolhida mostrada.

À Profa. Letícia Teixeira, do Departamento de Química da UFMG, pela síntese e disponibilização dos complexos de cobre.

Aos secretários do Departamento de Física PUC-Rio, Julinho, Giza e Márcia, pela enorme ajuda e disponibilidade quando precisei deles.

O presente trabalho foi realizado com apoio da Coordenação de Aperfeiçoamento de Pessoal de Nível Superior - Brasil (CAPES) - Código de Financiamento 001, e com apoio do Conselho Nacional de Desenvolvimento Científico e Tecnológico $(\mathrm{CNPq} / \mathrm{MCTI})$.

Ao povo brasileiro, pela qualidade de pessoas, sua amabilidade e carinho com que fui recebido e mantido até estes dias. Obrigado! 


\section{Resumo}

Incio, Jimmy Llontop; Louro, Sônia Renaux Wanderley (Orientadora). Estudos espectroscópicos de fluorquinolonas e seus complexos de cobre(II): interação com micelas, lipossomas e nanocompósitos de ouro. Rio de Janeiro, 2018. 120p. Tese de Doutorado - Departamento de Física, Pontifícia Universidade Católica do Rio de Janeiro.

Norfloxacina (NFX) é um antibiótico fluorescente de amplo espectro bacteriológico, membro da família das fluorquinolonas (FQs). A interação das FQs com íons metálicos pode incrementar a ação bactericida e agir contra a resistência das bactérias frente aos antibióticos. Diversos exemplos de complexos mistos de norfloxacina e $\mathrm{Cu}(\mathrm{II})$ podem ser encontrados na literatura. A compreensão dos mecanismos moleculares de interação desses antibióticos com os diferentes componentes das células e com nanopartículas de ouro, como transportadores do fármaco, é extremamente importante. Para entender essas interações, neste trabalho utilizamos diferentes técnicas espectroscópicas, como espectroscopia de fluorescência estacionária e resolvida no tempo, absorção de luz UV-Visível e ressonância paramagnética eletrônica (RPE). A interação de NFX e do complexo ternário $\mathrm{Cu}(\mathrm{II}): \mathrm{L}: \mathrm{NFX}$, onde o ligante L é a 1,10-fenantrolina (Phen) ou 2,2'bipiridina (Bipy), com micelas e lipossomas unilamelares pequenos de fosfatidilcolina de ovo (PC) foi estudada usando espectroscopia de fluorescência em estado estacionário e resolvida no tempo. Foi estudada a estabilidade dos complexos ternários formados em micelas. Foram obtidas constantes de estabilidade no interior de micelas de SDS, as quais mostraram valores muito maiores do que em tampão. Já os espectros de RPE deram maiores detalhes sobre a estrutura dos complexos e confirmaram a formação do complexo ternário dentro das micelas. Foram estudadas as interações de FQs e seus complexos de cobre com lipossomas de PC preparados com diferentes densidades superficiais de carga elétrica negativa. No estudo da interação de FQs com nanopartículas de ouro sintetizadas por ablação a laser (nanocompósitos, AuNCs), NFX mostrou maiores mudanças, tanto na absorbância como na fluorescência, do que as FQs ciprofloxacina (CFX) e levofloxacina (LFX). Os resultados sugerem mudanças no índice de refração na superfície dos AuNCs, por associação com o fármaco e/ou formação de aglomerados como resultado da interação. Observou-se também uma supressão lenta, porém significativa, na fluorescência da NFX, sem mudança na 
posição do pico, indicando que NFX mantém o seu estado inicial de protonação ligando-se à superfície dos AuNCs. Também foi observada a liberação de FQs ligadas à superfície de AuNPs mediante substituição por tióis, que ocasiona recuperação parcial da fluorescência da fluorquinolona. Por último, como o surfactante aniônico SDS se mostrou promissor na interação com NFX, em comparação com surfactantes catiônicos e neutros, e como os AuNCs são estáveis em SDS, estudamos a interação de NFX com AuNCs sintetizados em presença de SDS e, para comparação, com AuNCs colocados em solução de SDS após a síntese.

\section{Palavras-chave}

Complexos de cobre; fluorquinolonas; norfloxacina; micelas; lipossomas; nanopartículas de ouro; ablação a laser. 


\section{Abstract}

Incio, Jimmy Llontop; Louro, Sônia Renaux Wanderley (Advisor). Spectroscopic studies of fluoroquinolones and their copper(II) complexes: interaction with micelles, liposomes and gold nanocomposites. Rio de Janeiro, 2018. 120p. Tese de Doutorado Departamento de Física, Pontifícia Universidade Católica do Rio de Janeiro.

Norfloxacin (NFX) is a fluorescent antibiotic of broad bacteriological spectrum, member of the fluoroquinolone (FQ) family. The interaction of FQs with metal ions can increase the bactericidal action and act against antibiotics bacterial resistance. Several examples of mixed-ligand norfloxacin $\mathrm{Cu}$ (II) complexes can be found in the literature. Understanding the molecular mechanisms of interaction of these antibiotics with different cell components and with gold nanoparticles as drug transporters is extremely important. To clarify these interactions, we used different spectroscopic techniques, such as steady-state and time-resolved fluorescence spectroscopy, UV-Visible light absorption, and electron paramagnetic resonance (EPR). The interaction of NFX and the ternary complex Cu(II):L:NFX, where the $\mathrm{L}$ is the ligand 1,10-phenanthroline (Phen) or 2,2'-bipyridine (Bipy), with micelles and small unilamellar liposomes of egg phosphatidylcholine (PC) was studied using steady-state and time-resolved fluorescence spectroscopy. The stability of the ternary complexes formed in micelles was studied, and stability constants were obtained inside SDS micelles, which showed values much larger than in buffer. The EPR spectra gave further details on the structure of the complexes, and confirmed the formation of the ternary complex inside the micelles. The interactions of FQs and their copper complexes with PC liposomes prepared with different surface densities of negative electrical charge were studied. In the study of the interaction of FQs with gold nanoparticles synthesized by laser ablation (nanocomposites, AuNCs), NFX showed greater changes than FQs ciprofloxacin (CFX) and levofloxacin (LFX) in both absorbance and fluorescence. The results suggest changes in the surface refractive index of the AuNCs and/or cluster formation, as result of the interaction with the drug. A slow but significant quenching of NFX fluorescence was also observed, with no change in peak position, indicating that NFX maintains its initial state of protonation by binding to the surface of the AuNCs. Release of FQs attached to the surface of AuNCs by thiols has also been observed, which causes partial recovery of FQ fluorescence. Finally, as the anionic 
surfactant SDS showed to be promising in the interaction with NFX, compared to cationic and neutral surfactants, and because the AuNCs are stable in SDS, we studied the interaction of NFX with AuNCs synthesized in the presence of SDS and, for comparison, with AuNCs placed in SDS solution after synthesis.

\section{Keywords}

Copper complexes; fluoroquinolones; norfloxacin; micelles; liposomes; gold nanoparticles; laser ablation. 


\section{Sumário}

1 Introdução 19

$\begin{array}{lll}1.1 & \text { Objetivos } & 21\end{array}$

1.2 Estrutura dos capítulos 23

2 Espectroscopias de absorção, fluorescência e RPE 24

2.1 Absorção de luz UV-visível 24

2.2 Fluorescência estacionária e resolvida no tempo 26

$\begin{array}{lll}2.3 & \text { Supressão de fluorescência } & 27\end{array}$

2.4 Ressonância paramagnética eletrônica (RPE): princípios básicos 33

3 Quinolonas e fluorquinolonas 37

3.1 Quinolonas e sua interação com alvos biológicos 42

3.1.1 Membranas biológicas 43

3.1.2 Nanopartículas metálicas e sua interação com fluorquinolonas 46

$4 \quad$ Materiais e métodos $\quad 51$

4.1 Materiais 51

4.2 Técnicas experimentais 54

4.2.1 Absorção óptica $\quad 54$

$\begin{array}{lll}4.2 .2 \text { Fluorescência } & 55\end{array}$

4.2.3 Ressonância paramagnética eletrônica 59

$\begin{array}{lll}4.3 & \text { Procedimentos } & 60\end{array}$

4.3.1 Preparação de amostras 60

4.3.2 Interação de norfloxacina com complexos de cobre e com diferentes biomoléculas

5 Resultados e Discussões $\quad 65$

5.1 Interação dos complexos [ $\mathrm{CuCl}_{2}$ (Bipy)] e [ $\left.\mathrm{CuCl}_{2}(\mathrm{Phen})\right]$ com norfloxacina em micelas de SDS

5.1.1 Absorção e fluorescência da NFX em micelas de SDS titulada com os complexos Cu:Bipy e Cu:Phen

$\begin{array}{ll}\text { 5.1.2 Decaimento da fluorescência } & 71\end{array}$

$\begin{array}{ll}\text { 5.1.3 Ressonância paramagnética eletrônica } & 71\end{array}$

5.2 Influência de vesículas unilamelares pequenas de fosfatidilcolina de ovo na interação da norfloxacina com o complexo $\mathrm{Cu}$ :Phen

5.2.1 Vesículas unilamelares pequenas de fosfatidilcolina de ovo 
5.2.2 Vesículas unilamelares pequenas de fosfatidilcolina de ovo e ácido esteárico

5.2.3 Vesículas unilamelares pequenas de fosfatidilcolina de ovo e SDS

5.3 Interação da norfloxacina com DNA

5.4 Interação de fluorquinolonas com nanopartículas de ouro 86

5.4.1 Interação de NFX, CFX e LFX com AuNCs 86

5.4.2 Interação com AuNCs tratados com citrato

5.4.3 Interação de NFX com nanopartículas de ouro sintetizadas por via química em CTAB

5.4.4 Interação de NFX com AuNCs sintetizados em SDS 104

6 Conclusão e perspectivas

$7 \quad$ Referências bibliográficas 


\section{Lista de Figuras}

Figura 1.1. (a) Estrutura molecular geral das quinolona. (b) Estrutura das fluorquinolonas, mostrando suas duas modificações importantes.

Figura 2.1. Níveis de energia dos orbitais moleculares (HOMO: Highest Occupied Molecular Orbitals; LUMO: Lowest Unoccupied Molecular Orbitals) e possíveis transições eletrônicas (retirado de Valeur, 2001).

Figura 2.2. Comparação entre supressão dinâmica e estática respeito ao aumento de temperatura (modificado de Lakovicz, 2006).

Figura 2.3. Supressão dinâmica e estática de igual população de fluoróforos (modificado de Lakovicz, 2006).

Figura 2.4. Desdobramento dos níveis de energia do spin eletrônico na presença de um campo magnético externo $B$, a curva de absorção de energia do campo de micro-onda e sua derivada. (Modificado de Baffa, 1984)

Figura 3.1. Estrutura representativa de norfloxacina (1-ethyl-6-fluoro1,4-dihydro-4-oxo-7-(1-piperazinyl)-3-quinolinecarboxylic acid, NFX), indicando os pKa para o grupo amina da piperazina e o grupo ácido.

Figura 3.2. Estrutura representativa do equilíbrio químico de ionização da NFX, nos meios (a) ácido, (b) neutro e (c) alcalino [Mitscher, 2005].

Figura 3.3. Principais modos de coordenação das quinolonas [Uivarosi, 2013].

Figura 3.4. Estrutura geral do quelato de quinolona 1: 2 (metal: ligante) com cátions divalentes (Adaptado de Uivarosi, 2013).

Figura 3.5. Estruturas formadas por auto-agregação de surfactantes e lipídios (modificado de http://people.umass.edu/mcclemen/Group.html).

Figura 3.6. Distribuição de surfactante em solução aquosa. Efeito na tensão superficial e formação de micelas.

Figura 3.7. Esquema de distribuição de fármacos dentro de um lipossoma unilamelar.

Figura 3.8. Representação esquemática do método de ablação a laser, mostrando os principais componentes (modificado de Palazzo et al., 2017).

Figura 3.9. Representação esquemática de AuNPs produzida pelo método de Turkevich 
Figura 4.1. (a) Estruturas moleculares de levofloxacina, norfloxacina e ciprofloxacina. Estruturas propostas para os complexos de $\mathrm{Cu}(\mathrm{II})$ de norfloxacina: (b) $\left.\left[\mathrm{CuCl}_{2}(\mathrm{Bipy})(\mathrm{NFX})\right] \mathrm{Cl}\right]$, (c) $\left[\mathrm{CuCl}_{2}(\mathrm{Phen})(\mathrm{NFX})\right]$, (d) $\left[\mathrm{CuCl}_{2}\left(\mathrm{H}_{2} \mathrm{O}\right)(\mathrm{NFX})\right]$.

Figura 4.2. Estrutura molecular de (a) fosfatidilcolina de ovo (tamanho de cadeia variável), (b) dodecilsulfato de sódio (SDS), (c) brometo de cetiltrimetilamônio, (d) glutationa, (e) ácido esteárico

Figura 4.3. (a) Micrografia TSEM de AuNCs ajustando o pH do sistema de água com $\mathrm{NaOH}$. A inserção representa a distribuição estatística dos diâmetros das partículas. (b) Imagem HRTEM de um AuNC: o espaçamento de rede correspondendo a $\mathrm{Au}(0,235 \mathrm{~nm})$ e grafite $(0,330$ $\mathrm{nm}$ ) claramente visível no núcleo e na superfície, respectivamente. (c) Imagem HRSTEM e análise elementar de EDX (Espectroscopia de raios X por dispersão em energia) do mesmo AuNC [Del Rosso, 2016]

Figura 4.4. Esquema do funcionamento do espectrofotômetro (retirado da Tese de Doutorado de Romero, 2013).

Figura 4.5. Fotografia do Sistema de Fluorescência PTI-QM1 (Photon Technology International).

Figura 4.6. Esquema do espectrofluorímetro estacionário utilizado (Adaptado do manual do equipamento PTI QM1).

Figura 4.7. Esquema da técnica da contagem de fóton único. (Lakowicz;2006).

Figura 4.8. Equipamento de fluorescência resolvida no tempo utilizado para medidas de tempos de vida.

Figura 4.9. Laboratório de Ressonância Paramagnética Eletrônica (RPE), CBPF, mostrando o espectrômetro de RPE (http://mesonpi.cat.cbpf.br/matmult/?pgn=Infraestrutura\%20Associada RPE).

Figura 5.1. Esquema ilustrando a interação de Cu:Phen com NFX dentro das micelas de SDS. (Adaptado de Muniz, Incio et al., 2017).

Figura 5.2. Espectros de absorção da NFX $8 \mu \mathrm{M}$ em SDS $20 \mathrm{mM}$, titulada com cobre e seus complexos ( $\left.a_{1}\right)$ Cu:Bipy, $\left(b_{1}\right)$ Cu:Phen e ( $\left.c_{1}\right)$ o sal $\mathrm{CuCl}_{2}$. Espectros ( $\left.\mathrm{a}_{2}\right)$, ( $\left.\mathrm{b}_{2}\right)$ e ( $\left.\mathrm{c}_{2}\right)$ são resultados de subtrair o espectro inicial de cada série dos espectros (a $\left.a_{1}\right),\left(b_{1}\right),\left(c_{1}\right)$ (NFX em SDS).

Figura 5.3. Espectros de fluorescência da NFX $8 \mu \mathrm{M}$ em SDS $20 \mathrm{mM}$, e o efeito da titulação com (a) Cu:Bipy, (b) $\mathrm{Cu}: P h e n$ e (c) $\mathrm{CuCl}_{2}$. Medidas com excitação em $330 \mathrm{~nm}$.

Figura 5.4. (a) Gráficos de Stern-Volmer para a fluorescência da NFX em micelas de SDS, em $430 \mathrm{~nm}$, como função da concentração dos 
complexos de cobre e de $\mathrm{CuCl}_{2}$. (b) Variação normalizada da fluorescência da NFX como função da concentração dos complexos de $\mathrm{Cu}$ :Phen, Cu:Bipy e $\mathrm{Cu}: \mathrm{Cl}_{2}$. Linhas sólidas: ajustes por mínimos quadrados usando Eq. 4.2.

Figura 5.5. Decaimento da fluorescência da NFX em micelas de SDS e concentrações crescentes de Cu:Bipy. Excitação em 330 nm.

Figura 5.6. Espectros de RPE dos complexos Cu:Phen $(1,2)$ e Cu:Bipy $(3,4)$ em micelas de SDS na ausência de NFX $(1,3)$, e em micelas de SDS carregadas com NFX (2, 4). (77\% K, PB $10 \mathrm{mM}, \quad \mathrm{pH} 7,4)$ $[\mathrm{NFX}]=[\mathrm{Cu}:$ Bipy $]=[\mathrm{Cu}:$ Phen $]=\left(1 \times 10^{-3} \mathrm{M}\right) ;[\mathrm{SDS}]=25 \times 10^{-3} \mathrm{M}$.

Figura 5.7. Espectros de fluorescência da NFX $16 \mu \mathrm{M}$ (a1) em tampão PB $10 \mathrm{mM} \mathrm{pH}$ 7,4, (b 1 ) em PB na presença de SUVs de PC $10 \mathrm{mM}$; (a2) em tampão PBS $10 \mathrm{mM} 0.15 \mathrm{M} \mathrm{e}$ (b2) em PBS $10 \mathrm{mM}$ na presença de PC $10 \mathrm{mM}$, subtraindo previamente o espalhamento. Titulação com Cu:Phen. Excitação em $330 \mathrm{~nm}$.

Figura 5.8. Fluorescência da NFX (em $413 \mathrm{~nm}$ ) como função da concentração de $\mathrm{Cu}$ :Phen, em SUVs de PC em Pb e em PBS. (a $\left.a_{1}\right)$ e $\left(a_{2}\right)$ Gráficos de Stern-Volmer. ( $\left.b_{1}\right)$ e ( $\left.b_{2}\right)$ Variação da fluorescência normalizada à máxima variação (completa supressão). Linha solida: curva de ajuste por mínimos quadrados, usando Eq. 4.2.

Figura 5.9. Espectros de fluorescência da NFX $16 \mu \mathrm{M}$ com PC e SA (a) $0 \mathrm{mM}$, (b) $2 \mathrm{mM}$, (c) $4 \mathrm{mM}$ e (d) $6 \mathrm{mM}$ subtraindo o espectro do espalhamento. Todas as medidas foram em tampão PBS titulando com Cu:Phen. Excitação em $330 \mathrm{~nm}$.

Figura 5.10. Fluorescência da NFX como função da concentração de Cu:Phen, em SUVs de PC com diferentes proporções de SA. (a) Gráfico de Stern-Volmer. (b) Variação da fluorescência normalizada à máxima variação (completa supressão). Linha solida: curva de ajuste por mínimos quadrados, usando Eq. 4.2. Curva magenta: NFX em PBS. Pico de análise em $417 \mathrm{~nm}$.

Figura 5.11. Espectros de fluorescência da NFX $16 \mu \mathrm{M}$ com PC e SDS (a) $0 \mathrm{mM}$, (b) $2 \mathrm{mM}$, (c) $4 \mathrm{mM}$ e (d) $6 \mathrm{mM}$, subtraindo o espectro do espalhamento. Todas as medidas foram em tampão PBS titulando com Cu:Phen. Excitação em $330 \mathrm{~nm}$.

Figura 5.12. Fluorescência da NFX (em $422 \mathrm{~nm}$ ) como função da concentração de Cu:Phen, em SUVs de PC com diferentes proporções de SDS. (a) Gráficos de Stern-Volmer. (b) Variação da fluorescência normalizada à máxima variação (completa supressão). Linha solida: curva de ajuste por mínimos quadrados, usando Eq. 4.2.

Figura 5.13. Espectros de absorção de DNA em NFX $8 \mu \mathrm{M}$, subtraídos do espectro da NFX para diferentes concentrações. Linha tracejada: espectro de DNA puro $103 \mu \mathrm{M}$. 
Figura 5.14. Espectros de fluorescência da NFX $8 \mu \mathrm{M}$, em tampão TRIS, e o efeito da titulação com DNA. Excitação em $330 \mathrm{~nm}$.

Figura 5.15. Gráfico de Stern-Volmer para a supressão da fluorescência da NFX como função da concentração do DNA. A linha sólida representa a curva de ajuste para a obtenção da constante $\mathrm{K}_{\mathrm{b}}$.

Figura 5.16. Espectros de absorção/extinção de soluções tituladas com AuNCs. (a) apenas em tam-pão PO4, 2 mM, pH 7,8; (b) NFX 8,0 $\mu \mathrm{M}$ no mesmo tampão; (c) subtração dos espectros: (b) - (a).

Figura 5.17. (a) Espectros de fluorescência da NFX em tampão e o efeito da titulação com alíquotas de nanocompósitos de ouro. (b) Espectros de fluorescência da NFX corrigidos.

Figura 5.18. Decaimento da fluorescência da NFX em solução aquosa e a titulação com AuNCs.

Figura 5.19. Evolução temporal dos espectros de extinção dos AuNCs depois de adicionar CFX $77 \mu \mathrm{M}$. (absorbância dos AuNCs $A=1,23$ em $517 \mathrm{~nm}$, caminho óptico de $1 \mathrm{~cm}$ )

Figura 5.20. Espectros de absorção/extinção de NFX $40 \mu \mathrm{M}$ (magenta), AuNCs depois de tratar com $0,1 \mathrm{mM}$ de citrato (laranja) e evolução temporal dos espectros depois de adicionar NFX $40 \mu \mathrm{M}$. A superposição dos espectros de NFX e AuNCs também é mostrada, para comparação.

Figura 5.21. Análise dos espectros de absorção e extinção de NFX/AuNCs-citr mediante subtração entre espectros da Fig. 5.19: (a) espectros nos diferentes tempos subtraindo o espectro de AuNCs; (b) espectros nos diferentes tempos subtraindo o espectro inicial $(t=0)$; (c) espectros em diferentes tempos após subtrair $40 \%$ do espectro de NFX $40 \mu \mathrm{M}$.

Figura 5.22. (a) Espectros de fluorescência da NFX $40 \mu \mathrm{M}$ em AuNCscitr em diferentes instantes de tempo. (b) Espectros (a) corrigidos. Excitação em $330 \mathrm{~nm}$.

Figura 5.23. NFX/AuNCs-citr depois de adicionar GSH 6,7, 13 e $40 \mu \mathrm{M}$ e depois de dialisar contra citrato. (a) Absorção/extinção. Espectro preto é o espectro depois da diálise menos $40 \%$ antes da diálise. (b) Efeito da adição de GSH na fluorescência.

Figura 5.24. Espectros de absorção/extinção de LFX $40 \mu \mathrm{M}$ (magenta) e de AuNCs tratados com $0,1 \mathrm{mM}$ de citrato de sódio (laranja); evolução temporal dos espectros depois de adicionar LFX $40 \mu \mathrm{M}$.

Figura 5.25. Análise dos espectros de extinção mediante subtração espectral: espectros em diferentes tempos após adição de LFX subtraindo o espectro de AuNCs. 
Figura 5.26. (a) Espectros de fluorescência da LFX $40 \mu \mathrm{M}$ em AuNCscitr para cada intervalo de tempo. Excitação em $335 \mathrm{~nm}$. (b) Espectros de (a) corrigidos por efeito filtro, de acordo com a Eq. 4.5, com $\ell_{e m}=0,4$ $\mathrm{cm} \mathrm{e} \ell_{\text {exc }}=1,0 \mathrm{~cm}$.

Figura 5.27. Espectros de absorção/extinção de NFX em água (magenta), AuNP-CTAB antes (laranja) e depois (vermelho) de tratar com NFX $40 \mu \mathrm{M}$. O espectro manteve-se inalterado por 10 dias (azul). 100

Figura 5.28. Espectros de fluorescência da NFX $40 \mu \mathrm{M}$ em AuNPCTAB, em diferentes intervalos de tempo após adição. Espectros corrigidos de acordo com a Eq. 4.5, lexc $=0,4 \mathrm{~cm}$ e lem $=1,0 \mathrm{~cm}$. Exc. $330 \mathrm{~nm}$.

Figura 5.29. Espectros de absorção/extinção de (a) AuNP-CTAB com NFX antes e após adicionar $\mathrm{PO}_{4} 1 \mathrm{mM}$. Amostras medidas em diferentes intervalos de tempo. (b) Controle: AuNP-CTAB antes e após adicionar tampão $\mathrm{PO}_{4} 1 \mathrm{mM}, \mathrm{pH}$ 7,4.

Figura 5.30. (a) Espectros de fluorescência da NFX $40 \mu \mathrm{M}$ em AuNPCTAB antes e depois de tamponar a solução com PB, para cada instante de tempo. Excitação em $330 \mathrm{~nm}$. (b) Espectros de (a) corrigidos de acordo com Eq. 4.5.

Figura 5.31. Espectros de absorção/extinção de AuNCs sintetizados em SDS $10 \mathrm{mM}$ (AuNC-SDS) antes (vermelho) e após adicionar NFX $10 \mu \mathrm{M}$ (verde), $20 \mu \mathrm{M}$ (azul) e $40 \mu \mathrm{M}$ (magenta). O espectro de NFX $10 \mu \mathrm{M}$ em SDS (preto) é também mostrado.

Figura 5.32. Espectros de fluorescência da NFX $10 \mu \mathrm{M}$ em AuNC-SDS, para cada instante de tempo. (a) sem correção; (b) corrigidos conforme Eq. 4.5. Exc. $330 \mathrm{~nm}$.

Figura 5.33. Espectros de fluorescência da NFX $20 \mu \mathrm{M}$ (a) e $40 \mu \mathrm{M}$ (b) em AuNC-SDS para cada instante de tempo, corrigidos conforme Eq. 4.5. Exc. $330 \mathrm{~nm}$.

Figura 5.34. Espectros de fluorescência corrigidos de NFX 10 (a), 20 (b) e $40 \mu \mathrm{M}$ (c) em AuNCs adicionando SDS $10 \mathrm{mM}$ após ablação, para cada instante de tempo. Excitação em $330 \mathrm{~nm}$. 


\section{Lista de abreviaturas}

AuNPs Nanopartículas de ouro

AuNCs Nanocompósitos de ouro sintetizados por ablação a laser

Bipy 2,2'-bipiridina (2,2'-bipyridine)

CFX Ciprofloxacina

CMC Concentração micelar crítica

CTAB Brometo de cetiltrimetilamonio (cetyltrimethylammonium bromide)

$\mathrm{Cu}: \mathrm{Phen} \quad\left[\mathrm{CuCl}_{2}\right.$ (Phen) $]$

$\phi_{F} \quad$ Eficiência quântica de fluorescência

FQs Fluorquinolonas

GSH Glutationa

$K_{b} \quad$ Constante de associação

LFX Levofloxacina

Norfloxacina

$\mathrm{PB}$

Tampão fosfato (do inglês, phosphate buffer)

PBS Tampão fosfato salino

PC Fosfatidilcolina (phosphatidylcholine, lecitina) de ovo

Phen 1,10-fenantrolina (1,10-phenanthroline)

SA Ácido esteárico (do inglês, stearic acid)

SDS Dodecil sulfato de sódio 
Talvez não tenha conseguido fazer o melhor, mas lutei para que o melhor fosse feito. Não sou o que deveria ser, mas graças a Deus, não sou "o que era antes".

Martin Luther King 


\section{Introdução}

A resistência aos antibióticos é uma preocupação crescente na medicina e leva à necessidade de desenvolver e desenhar novas moléculas, potenciais fármacos, que possam inibir eficazmente a replicação bacteriana. Várias soluções têm sido tentadas, entre elas a síntese de complexos metálicos de alguns antibióticos já bastante utilizados clinicamente [Möhler et al., 2017; Cuprys et al., 2018].

Fluorquinolonas, FQs, (Fig. 1.1) são antibióticos que têm um grande espectro de ação contra bactérias, boa absorção e biodisponibilidade [Appelbaum et al., 2000]. Uma estratégia para aumentar sua atuação farmacológica, tentar neutralizar a resistência bacteriana e ampliar o espectro de ação a outros micro-organismos, como o Tripanossoma cruzi, é a sua coordenação a íons metálicos e formação de complexos mistos [Köpf-Maier, 1994; Psomas et al., 2013; Abd El-Halim et al., 2011; Sultana et al., 2010]. Esses complexos, relativamente estáveis, modificam a potência e a especificidade das FQs, e podem influenciar sua translocação através das membranas bacterianas.

(a)<smiles>[R][Y4]1c2[Y4]([R9])nc(C(=O)O)c(=O)c2C=[Y9]([R])C1[R]</smiles><smiles>[R][Y]c1[Y4](C(=O)O)n([R9])c(F)c1N1CCNCC1</smiles>

(b)

Figura 1.1. (a) Estrutura molecular geral das quinolona. (b) Estrutura das fluorquinolonas, mostrando suas duas modificações importantes.

Dos processos biológicos que ocorrem nas membranas, muitos deles ocorrem na superfície ou conjuntamente em seu interior hidrofóbico. Devido aos grupos ionizáveis dos lipídeos, a superfície das membranas biológicas frequentemente se apresenta carregada, permitindo assim a formação de diferentes ligações de 
espécies moleculares que apresentam grupos ionizáveis carregados ou não carregados. Diversos trabalhos de sistemas biológicos e fármacos têm sido realizados com o fim de analisar os efeitos funcionais no sistema [Kutchai et al., 2001, Sakaguchi et al., 2006, Cassuto et al., 2006]. A compreensão dos mecanismos moleculares de interação desses antibióticos com diferentes componentes das células é extremamente importante.

Por outro lado, técnicas experimentais têm sido aplicadas para investigar as propriedades físico-químicas de vários fármacos, como por exemplo, efeitos de anestésicos na estrutura molecular dentro da bicamada lipídica e na diminuição da liberdade de movimento das moléculas quando ligadas à membrana [Lee, 1976, Ohki, 1984, Barriviera et al., 2005, Ragsdale et al., 1994].

Para entender interações das FQs com sistemas de interesse biológico, neste trabalho utilizamos diferentes técnicas espectroscópicas, tais como espectroscopia de fluorescência estacionária e resolvida no tempo, a absorção de luz na faixa do UV-Visível e ressonância de spin eletrônico (RPE). As FQs, em sua maioria, são fluorescentes e, portanto, são especialmente adequadas ao estudo por fluorescência, pois não necessitam de marcadores extrínsecos que podem modificar o sistema estudado. Íons de metais de transição, especialmente o cobre (II), são paramagnéticos, e em geral respondem à técnica de RPE.

Em estudos de interação dos fármacos com os componentes celulares, modos de interação de antibióticos com DNA podem ser avaliados através de titulações espectrofotométricas de absorção na região do UV-Vis. Assim, pode-se medir a intensidade da interação fármaco-proteína e identificar o modo de interação [Paraginski, 2007]. Nesses estudos de interação de fármacos com DNA, diversos estudos in vitro se encontram na literatura, utilizando diferentes associações entre quinolonas e íons de metais bivalentes [Song et al., 2005; Drevenšek et al., 2003; Guo et al., 2011; Robles et al., 2000]. Quando ocorre interação eletrostática ou intercalação fármaco-DNA, observa-se diminuição da absortividade molar, e/ou um desvio para a região do vermelho da banda de absorção do composto (hipocromismo e batocromismo, respectivamente). Já quando a estrutura secundária do DNA é quebrada, observa-se um aumento da absortividade molar e/ou um desvio para a região do azul (hipercromismo e hipsocromismo, respectivamente) [Paraginski, 2007; Firdaus et al., 2008]. 
Nanopartículas de metais nobres têm sido, atualmente, centro da atenção de alguns estudos interessantes, devido às suas propriedades ópticas únicas, surgindo da ressonância de plasmon superficial (SPR). Entre essas nanopartículas, o ouro e a prata são considerados bem interessantes devido à banda de ressonância de plasmon estar localizada na região visível do espectro eletromagnético, e as mudanças dessas bandas quando interagem com outras moléculas podem ser bem observadas [Jain et al., 2008]. Nanopartículas de ouro (AuNPs), como nanoestruturas bem definidas, têm sido empregadas para diversas aplicações potencias nas áreas das ciências físicas, químicas e bioquímicas.

Supressão de fluorescência é o processo no qual a intensidade de fluorescência de um fluoróforo diminui. Recentemente, devido ao seu alto coeficiente de extinção e às suas propriedades ópticas altamente dependentes da distância, AuNPs têm sido utilizadas como supressores por transferência de energia [Ghosh et al., 2012; Gao et al., 2011; Guo et al., 2011]. Essa supressão por AuNPs pode ser utilizada para sensoriamento de analitos mediante turn-on/off da fluorescência. Após a adição de um analito alvo, fluoróforos ou moléculas receptoras marcadas com fluoróforos são removidas da superfície das AuNPs. Como resultado, a intensidade de fluorescência dos fluoróforos aumenta com o incremento da concentração do analito [Darbha et al., 2007; Chen et al., 2009].

Em nosso estudo com as AuNPs foram investigadas modificações da fluorescência de algumas FQs por AuNPs, utilizando nanopartículas de ouro sintetizadas via ablação a laser. Estas nanopartículas possuem uma camada de carbonóides na superfície [Del Rosso, 2016] e por isso serão aqui chamadas de nanocompósitos de ouro (AuNCs). Entre as FQs utilizadas junto com os AuNCs temos a norfloxacina (NFX), ciprofloxacina (CFX) e levofloxacina (LFX). Também se estudou a restauração parcial da fluorescência da FQ por adição de tióis, devido à forte interação entre os tióis e nanopartículas de ouro para formar ligações Au-S, o que desloca a FQ da superfície das AuNPs [Amjadi e Farzampour, 2013].

\section{1}

\section{Objetivos}

Nesse trabalho, o objetivo geral foi estudar, através de técnicas espectroscópicas, a formação de complexos de fluorquinolonas com íons de 
cobre(II) e os mecanismos de interação com as diferentes biomoléculas e nanopartículas de ouro sintetizadas via ablação a laser.

Nossa abordagem se baseia na sensibilidade das propriedades óticas das moléculas e das propriedades magnéticas dos íons de cobre ao interagir com biomoléculas para formar complexos. Foram estudadas as propriedades das interações das FQs para avaliar associação, distribuição, e influência na atividade antibacteriana.

Usamos as técnicas espectroscópicas de absorção e fluorescência, tanto estacionária como resolvida no tempo, assim como ressonância paramagnética eletrônica. Estudamos a interação de NFX com os complexos (1,10fenantrolina)cobre(II) (Cu:Phen) e dicloro(2, 2'-bipiridina)cobre(II) (Cu:Bipy) em presença de biomembranas e de sistemas modelos.

Neste trabalho também estudamos a interação de NFX, CFX e LFX com nanocompósitos de ouro, e comparamos com a interação de nanopartículas de ouro sintetizadas por via química. Devido à forte interação de AuNCs com tióis, estudouse também a liberação de FQs ligadas à superfície dos AuNCs causada por adição de compostos contendo tióis e analisando a restauração da fluorescência.

Como objetivos específicos, temos:

- Estudo da formação de complexos de metais de transição por supressão de fluorescência da NFX, devido a que íons paramagnéticos são fortes supressores de fluorescência. Esse estudo permite obter as constantes de formação de complexos mistos em diferentes condições de $\mathrm{pH}$, força iônica.

- Análise da variação dos tempos de vida na supressão de fluorescência ao aumentar a concentração do supressor na formação do complexo ternário.

- Estudo da influência da presença de micelas na formação desses complexos. Análise dos espectros de RPE (ressonância paramagnética eletrônica) dos complexos e verificação das mudanças na estrutura ao interagir com as micelas.

- Estudo da influência da presença de vesículas na formação desses complexos. Ver como é afetada a formação dos complexos mistos de NFX com $\mathrm{Cu}:$ Phen pela associação a lipossomas unilamelares de lipídios. Obter constantes de associação do complexo ternário nesses sistemas e, mediante adição de moléculas negativas, como ácido esteárico e SDS, verificar se essas moléculas facilitam a formação do complexo. 
- Estudo da interação da NFX, CFX e LFX com nanocompósitos de ouro, e procura de condições adequadas para que se associem à superfície das nanopartículas.

\section{2}

\section{Estrutura dos capítulos}

No capítulo 2 fazemos uma breve descrição dos fundamentos teóricos e experimentais das técnicas de espectroscopia de absorção e de fluorescência, tanto estacionária como resolvida no tempo, assim como da técnica de ressonância paramagnética eletrônica.

No capítulo 3 apresentamos uma descrição sobre FQs e sua importância, em especial a norfloxacina e sua estrutura molecular. Fazemos também uma breve apresentação sobre biomembranas e as suas interações com FQs, AuNCs e interações com NFX, CFX e LFX.

No capítulo 4 descrevemos os materiais, equipamentos e métodos que empregamos na obtenção das medidas espectroscópicas e na análise dos espectros.

No capítulo 5 são apresentadas os resultados experimentais e discussões sobre os resultados obtidos, fazendo um paralelo com os que temos na literatura.

Finalmente, no capítulo 6, se apresentam as conclusões gerais desse trabalho. 


\section{Espectroscopias de absorção, fluorescência e RPE}

Princípios básicos das espectroscopias de absorção UV-Visível, fluorescência e RPE são descritos em excelentes textos como, por exemplo, Valeur (2001), Lakowicz (2006), Weil et al. (1994), Swartz et al. (1972). Segue abaixo um breve resumo dessas técnicas espectroscópicas empregadas nessa tese.

\section{1}

\section{Absorção de luz UV-visível}

Quando o elétron passa de um orbital molecular no estado fundamental para um orbital livre absorvendo um fóton, se diz que ocorreu uma transição eletrônica. Nesse caso a molécula se encontra em um estado excitado.

Um orbital molecular é uma função matemática que descreve o comportamento ondulatório de um elétron em uma molécula. Os orbitais moleculares são geralmente construídos pela combinação de orbitais atômicos ou orbitais híbridos de cada átomo da molécula, ou outros orbitais moleculares de grupos de átomos. Existem vários tipos de orbitais moleculares. $\mathrm{O}$ orbital $\sigma$ pode ser formado por dois orbitais atômicos $\mathbf{s}$, um $\mathbf{s}$ e um $\mathrm{p}$, ou por dois orbitais $\mathrm{p}$ tendo um eixo colinear de simetria. A ligação formada deste modo é chamada de ligação $\sigma$.

Um orbital $\pi$ é formado a partir de dois orbitais atômicos p sobrepostos lateralmente. A ligação resultante é chamada de ligação $\pi$. A absorção de um fóton com energia apropriada pode promover a passagem de um dos elétrons $\pi$ para um orbital não ocupado denominado $\pi^{*}$. Esta transição é chamada $\pi \rightarrow \pi^{*}$.

Uma molécula também pode possuir elétrons não ligados localizados em heteroátomos, tais como oxigênio ou nitrogênio. Os orbitais moleculares correspondentes são chamados orbitais $\mathbf{n}$. A excitação de um elétron não ligado para um orbital não ocupado é possível e a transição associada é denotada por $\mathbf{n} \rightarrow \pi^{*}$.

A energia dessas transições eletrônicas está, geralmente, na seguinte ordem: 


$$
\mathbf{n} \rightarrow \pi^{*}<\pi \rightarrow \pi^{*}<\mathbf{n} \rightarrow \sigma^{*}<\sigma \rightarrow \pi^{*}<\sigma \rightarrow \sigma^{*}
$$

Como exemplo, podemos ver na Fig. 2.1 os níveis de energia e as transições possíveis.

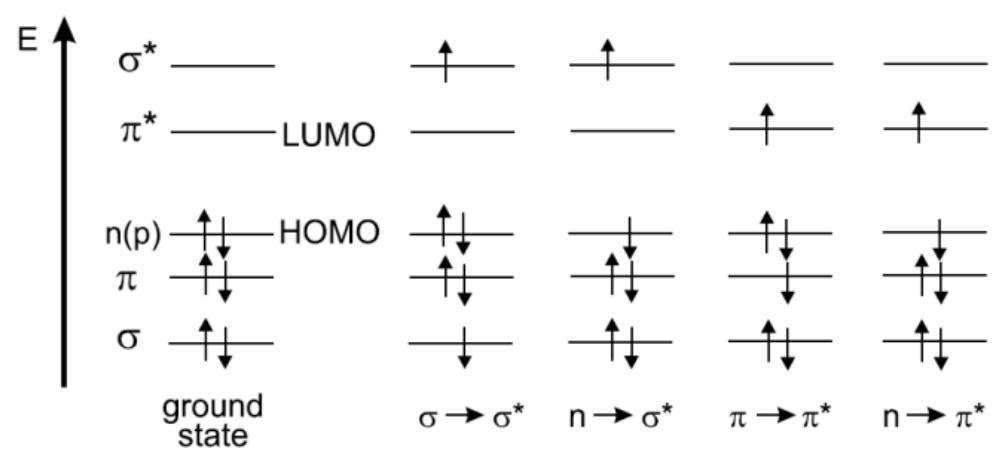

Figura 2.1. Níveis de energia dos orbitais moleculares (HOMO: Highest Occupied Molecular Orbitals; LUMO: Lowest Unoccupied Molecular Orbitals) e possíveis transições eletrônicas (retirado de Valeur, 2001).

Em espectroscopia de absorção e fluorescência consideram-se dois tipos importantes de orbitais: o orbital molecular ocupado de mais alta energia (HOMO) e o orbital molecular desocupado de mais baixa energia (LUMO). Ambos se referem ao estado fundamental de uma molécula.

\section{Lei de Beer-Lambert}

Se a luz de intensidade $I_{\lambda}^{0}$ passa através de uma substância (que pode estar em solução) de espessura $d$ e concentração molar $c$, a intensidade $I_{\lambda}$ da luz transmitida obedece a lei de Beer-Lambert:

$$
I(\lambda)=I_{\lambda}^{0} 10^{\varepsilon_{(\lambda)} \cdot d . c} \text { ou } A(\lambda)=\log \frac{I_{\lambda}^{0}}{I_{\lambda}}=\varepsilon_{(\lambda)} . d . c
$$

em que $\varepsilon$ é o coeficiente de absorção molar, que caracteriza a probabilidade de absorção para um único comprimento de onda, e $A$ é a absorbância da amostra. A espessura $d$ também é denominada de caminho óptico. Quando $d=1 \mathrm{~cm}$, a absorbância é comumente chamado de densidade ótica $(\mathrm{OD} \lambda)$, e o índice $\lambda$ informa o comprimento de onda em que a medida foi feita. A densidade ótica é conveniente, pois aqui a absorbância é igual a $\varepsilon . c$. Em alguns casos, se a concentração é alta, $\varepsilon$ aparece como uma função de $c$ e, portanto, a absorbância se desvia da linearidade. Neste caso se diz que a lei de Beer-Lambert não é válida. Isto pode resultar da alta absorção, do espalhamento, agregação, etc. 


\section{2}

\section{Fluorescência estacionária e resolvida no tempo}

Medidas de fluorescência podem ser classificadas em dois tipos principais: medidas no estado estacionário e resolvida no tempo. Medidas no estado estacionário são aquelas realizadas com uma fonte de luz emitindo um feixe contínuo sobre a amostra, registrando mediante um software adequado o espectro de emissão. Quando a luz atinge a amostra, o estado estacionário é alcançado quase que imediatamente. Já na fluorescência resolvida no tempo, é utilizada para medir intensidades e tempos de decaimento de fluorescência. Aqui a amostra é exposta a um pulso de luz mais curto que o tempo de decaimento da amostra. Esta intensidade de decaimento é registrada com um sistema de alta velocidade de detecção que permite medir a intensidade e a anisotropia de fluorescência em uma escala de tempo de nanossegundos.

Dada uma solução diluída de espécies fluorescentes de concentração $[A]$ (mol $\mathrm{L}^{-1}$ ), um pulso de luz muito curto no tempo $t=0$ leva uma população de moléculas, $A$, ao estado excitado singleto $\mathrm{S}_{1}$ através da absorção de fótons. Esta população de moléculas no estado excitado, ${ }^{l} A *$, então retornam ao estado $\mathrm{S}_{0}$, através dos processos radiativos e não radiativos. A população no estado excitado decai a uma taxa $\kappa=\left(k_{r}^{s}+k_{n r}^{s}\right)$, descrita na equação diferencial dada por:

$$
\frac{d\left[{ }^{1} A^{*}\right]}{d t}=-\kappa\left[{ }^{1} A^{*}\right]=-\left(k_{r}^{s}+k_{n r}^{s}\right)\left[{ }^{1} A^{*}\right]
$$

cuja solução vem dada por:

$$
\left[{ }^{1} A^{*}\right]=\left[{ }^{1} A^{*}\right]_{0} \exp \left(-t / \tau_{s}\right)
$$

onde $\left[{ }^{1} A^{*}\right]_{0}$ é a concentração de moléculas no estado excitado no tempo $t=0$ e $\tau_{\mathrm{s}}$ é o tempo de vida do estado excitado $S_{1}$, dado por:

$$
\tau_{s}=\frac{1}{\kappa}=\frac{1}{k_{r}^{s}+k_{n r}^{s}}
$$

No tempo $t$ após a excitação da amostra por um pulso de luz no tempo igual a 0 , a intensidade de fluorescência $i_{F}$ é proporcional, em qualquer tempo, à concentração instantânea de moléculas no estado excitado, $\left[{ }^{1} \mathrm{~A}^{*}\right]$; o fator de proporcionalidade é dado pela taxa radiativa $k_{r}^{s}$ : 


$$
i_{F}(t)=k_{r}^{s}\left[{ }^{1} A^{*}\right]=k_{r}^{s}\left[{ }^{1} A^{*}\right]_{0} \exp \left(-\frac{t}{\tau_{s}}\right)
$$

onde $i_{F}(t)$ é a resposta instantânea do sistema, o qual diminui exponencialmente.

O tempo de decaimento de fluorescência $\tau_{s}$ é a propriedade mais importante de uma molécula fluorescente, porque define a janela temporal em que podemos observar o fenômeno dinâmico do sistema.

O rendimento quântico de fluorescência $\Phi_{\text {Fluor }}$ é definido como a fração de moléculas no estado excitado que retornam ao estado fundamental $\mathrm{S}_{0}$ emitindo fótons. Assim, temos:

$$
\Phi_{\text {Fluor }}=\frac{k_{r}^{s}}{k_{r}^{s}+k_{n r}^{s}}=k_{r}^{s} \tau_{s}
$$

Por outro lado, o rendimento quântico de fluorescência é a razão do número de fótons emitidos (ao longo de toda a duração do decaimento) pelo número de fótons absorvidos. De acordo com a equação (2.5), a razão de $i_{F}(t)$ pelo número de fótons absorvidos é dada por:

$$
\frac{i_{F}(t)}{\left[{ }^{1} A^{*}\right]_{0}}=k_{r}^{s} \exp \left(-\frac{t}{\tau_{s}}\right)
$$

onde a integração desta relação em toda a duração do decaimento nos fornece o rendimento quântico, de modo que:

$$
\frac{1}{\left[{ }^{1} A^{*}\right]_{0}} \int_{0}^{\infty} i_{F}(t) d t=k_{r}^{s} \tau_{s}=\Phi_{F}
$$

Detalhes das técnicas de fluorescência estacionária e resolvida no tempo são descritas nos excelentes textos de Valeur (2001) e Lakowicz (2006).

\section{3}

\section{Supressão de fluorescência}

A intensidade de fluorescência de uma amostra pode ser diminuída por muitos processos. Esta diminuição é chamada de supressão e pode ocorrer devido a reações no estado excitado, rearranjos moleculares, transferência de energia, formação de complexos e supressão por colisão (dinâmica). Adicional aos processos descritos anteriormente, também pode existir supressão aparente devido 
a propriedades ópticas da amostra, tais como alta densidade ótica ou turbidez; mas este processo contém pouca informação molecular, assim que iremos assumir que tais efeitos são mínimos e não influem na supressão.

Os dois tipos principais de supressão, colisional e estática, requerem contato entre o fluoróforo e o supressor. No caso da supressão colisional, que através dos choques retira energia do estado excitado diminuindo a emissão fluorescente, o supressor se difunde no meio e choca-se com o fluoróforo durante o tempo de vida do seu estado excitado. Após o contato, o fluoróforo retorna ao estado fundamental sem a emissão de fótons (em geral, a supressão colisional ocorre sem nenhuma alteração permanente na molécula, ou seja, sem reação fotoquímica). Já na supressão estática, um complexo não fluorescente é formado entre o fluoróforo e o supressor no estado fundamental. Portanto, para que ocorra o fenômeno da supressão, em qualquer dos dois casos, o fluoróforo e o supressor devem entrar em contato.

\section{Supressores de fluorescência}

Há uma variedade muito grande de substâncias que agem como supressores de fluorescência. Um dos mais conhecidos supressores colisionais é a molécula de oxigênio, supressor de fluorescência de muitos fluoróforos. As aminas aromáticas e alifáticas são também eficientes supressores da maioria dos hidrocarbonetos aromáticos não substituídos. Outro tipo de supressão é devido a átomos pesados tais como iodeto e brometo. Os compostos halogenados atuam também como supressores colisionais.

Para mais informações, podemos encontrar uma variedade de supresores de fuorescência na Tabela 8.1 do livro Lakovicz, 2006.

A seguir, trataremos com mais detalhes os tipos de supressão dinâmica e estática e também falaremos dos outros tipos.

\section{Teoria da supressão dinâmica de fluorescência}

Na supressão dinâmica (também chamada de supressão colisional), a diminuição da intensidade fluorescência é descrita pela equação de Stern-Volmer:

$$
\frac{F_{0}}{F}=1+k_{q} \tau_{0}[Q]=1+K_{D}[Q]
$$


onde $F_{0}$ e $F$ são as intensidades de fluorescência na ausência e presença do supressor, respectivamente, $k_{q}$ é a constante bimolecular de supressão; $\tau_{0}$ é o tempo de vida do fluoróforo na ausência do supressor, $K_{D}$ é constante de supressão de Stern-Volmer e $[Q]$ é a concentração do supressor. A constante de supressão bimolecular, $k_{q}$, nos dá informação da eficiência da supressão ou a acessibilidade dos fluoróforos aos supressores. As medidas de supressão são geralmente representadas em um gráfico de $\left(\left(F_{0} / F\right)-1\right)$ versus $[Q]$. Deste modo, espera-se que $\left(F_{0} / F-1\right)$ seja linearmente dependente da concentração de supressor, para obter as constantes de supressão.

Um ajuste linear é indicado quando existe uma classe única de fluoróforos, estando todos acessíveis ao supressor. Caso contrário, por exemplo, se duas populações de fluoróforo estiverem presentes e uma classe não estiver acessível ao supressor, então os gráficos de Stern-Volmer desviam-se da linearidade em direção ao eixo x. Este resultado é frequentemente encontrado para a supressão da fluorescência do triptofano em proteínas por supressores polares ou carregados. Estas moléculas não penetram rapidamente no interior hidrofóbico das proteínas, e apenas os resíduos de triptofano na superfície da proteína tem a fluorescência suprimida.

Outra importante característica da supressão colisional é a equivalência entre a diminuição da intensidade de fluorescência e do tempo de vida, ilustrada pelas equações:

$$
\frac{\tau_{0}}{\tau}=1+k_{q} \tau_{0}[Q]
$$

De modo que,

$$
\frac{F_{0}}{F}=\frac{\tau_{0}}{\tau}
$$

A diminuição do tempo de vida ocorre devido à diminuição da população do estado excitado devido à desexcitação por colisão sem emissão de fótons. Já a supressão estática não diminui o tempo de vida porque somente moléculas fluorescentes são observadas e os fluoróforos que não formaram complexos possuem o mesmo tempo de vida $\tau_{0}$. 


\section{Teoria da supressão estática de fluorescência}

O fenômeno da supressão pode também ocorrer como resultado da formação de um complexo não fluorescente entre o fluoróforo e o supressor. Aqui, quando o complexo absorve luz, ele retorna imediatamente ao estado fundamental sem a emissão de fóton. Quando isso ocorre dizemos que a supressão é estática e é descrita por:

$$
\frac{F_{0}}{F}=1+K_{S}[Q]
$$

, onde $K_{S}$ é a constante de associação da reação, dada por $K s=\frac{[F-Q]}{[F][Q]}$.

Note que a dependência de $\mathrm{F}_{0} / \mathrm{F}$ de $[Q]$ é linear, o que é idêntico para a supressão dinâmica, exceto pelo fato de que a constante de supressão agora é a própria constante de associação.

Medidas de tempo de vida de fluorescência são as formas mais definitivas de distinguir entre uma supressão estática e uma dinâmica. A supressão estática remove a fração de fluoróforos da observação, pois os complexos formados são não fluorescentes. A fração de fluoróforos que não formaram complexos possui então um tempo de vida $\tau_{0}$. Para a supressão estática $\tau_{0} / \tau=1$. Em contraste com a supressão dinâmica onde $\tau_{0} / \tau=F_{0} / F$.

Outro método para distinguir supressão estática de supressão dinâmica é examinando cuidadosamente o espectro de absorção do fluoróforo. Supressão colisional afeta somente os estados excitados dos fluoróforos e, portanto, não altera o espectro de absorção. Em contraste, a formação de complexos no estado fundamental frequentemente resulta em uma perturbação no espectro de absorção do fluoróforo.

As supressões estática e dinâmica também podem serem distinguidas pela sua diferente dependência da temperatura e viscosidade ou, preferencialmente, por medições de tempo de vida de fluorescência. Temperaturas mais elevadas resultam em uma difusão mais rápida e, portanto, maiores quantidades de colisão com supressores (Fig. 2.2). Por outro lado, uma temperatura mais elevada irá tipicamente resultar na dissociação de complexos fracamente ligados e, portanto, quantidades menores de supressão estática. 
Supressão Colisional

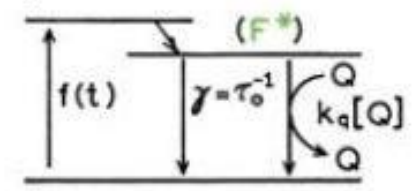

supressão Estática

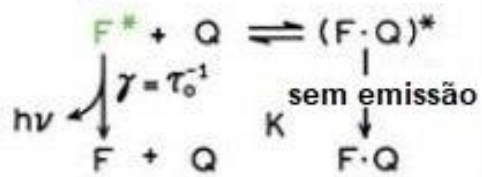

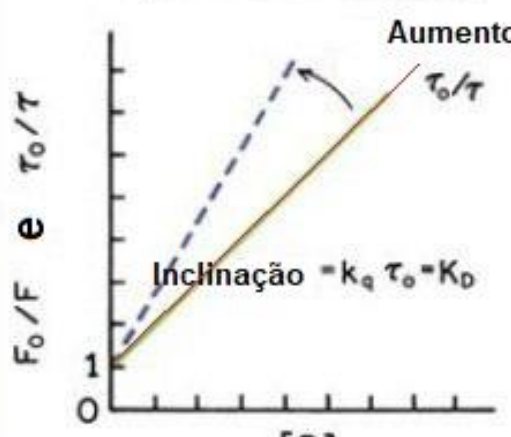

[Q]

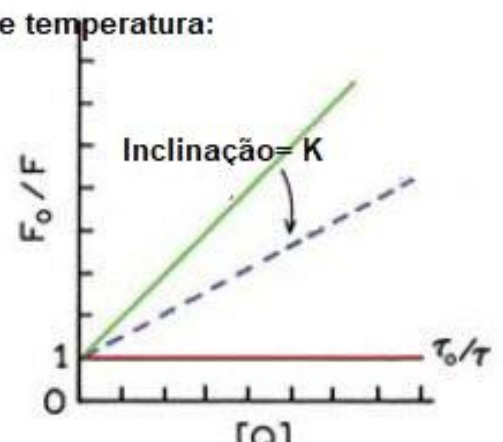

[Q]

Figura 2.2. Comparação entre supressão dinâmica e estática respeito ao aumento de temperatura (modificado de Lakovicz, 2006).

\section{Supressão dinâmica e estática combinada}

Em muitas situações a fluorescência pode ser suprimida por ambos os tipos de supressão: dinâmica (colidindo com o supressor), e estática (formando complexos não fluorescentes). Neste caso, a equação de Stern-Volmer é modificada e possui um termo não linear, de segunda ordem em $[Q]$. O que resulta em uma concavidade positiva na curva em direção ao eixo Y (Fig. 2.3). Deste modo, temos:

$$
\frac{F_{0}}{F}=1+K_{a p p}[Q]=1+\left(k_{S}+K_{D}\right)[Q]+K_{S} K_{D}[Q]^{2}
$$

onde $K_{a p p}=\left(K_{D}+K_{S}\right)+K_{D} K_{S}[Q]$ depende da concentração de supressor. Além disso, podemos observar aqui a forma da curva que corresponderia à de uma parábola quando ambas supressões dinâmica e estática ocorram.

Vemos que, um gráfico de $\frac{F_{0}}{F}-1$ versus [Q] conduziria a uma linha reta atravessando o eixo $\mathrm{Y}$ no ponto $\mathrm{K}_{\mathrm{S}}+\mathrm{K}_{\mathrm{D}}$, e com inclinação $\mathrm{K}_{\mathrm{S}}{ } \mathrm{K}_{\mathrm{D}}$. A componente dinâmica pode geralmente ser selecionada para ser uma solução comparável em magnitude ao valor esperado controlado por difusão, pela temperatura ou pela dependência de valores da viscosidade, ou a partir de outras informações disponíveis sobre a amostra. 

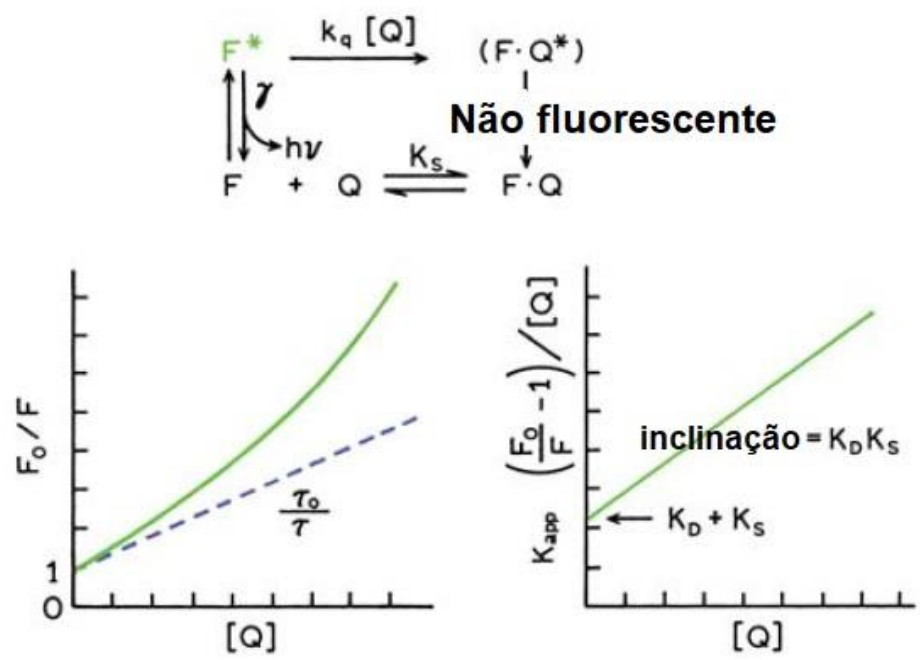

Figura 2.3. Supressão dinâmica e estática de igual população de fluoróforos (modificado de Lakovicz, 2006).

\section{Constante de supressão bimolecular}

Em muitos relatos sobre supressão, encontra-se frequentemente a constante de supressão bimolecular $\left(k_{q}\right)$, que reflete a eficiência de supressão ou a acessibilidade dos fluoróforos ao supressor. Conforme ilustrado abaixo, a supressão controlada por difusão resulta tipicamente em valores de $\mathrm{k}_{\mathrm{q}}$ próximos de 1 x $10^{10}$ $\mathrm{M}^{-1} \mathrm{~s}^{-1}$. Valores de $\mathrm{k}_{\mathrm{q}}$ menores do que a constante da reação controlada por difusão, $\mathrm{K}_{\mathrm{D}}$ [Gordon, 1984], podem resultar da blindagem estérica do fluoróforo ou de uma baixa eficiência de supressão. Já valores aparentes de $\mathrm{k}_{\mathrm{q}}$ maiores do que $\mathrm{K}_{\mathrm{D}}$ indicam usualmente algum tipo de interação por ligação.

Devido à condição de contato entre supressor e fluoróforo, existem numerosas aplicações da supressão. Uma dessas aplicações pode revelar a acessibilidade do fluoróforo ao supressor. Se considerarmos um fluoróforo ligado já seja a uma proteína ou a uma membrana, se um deles for impermeável ao supressor, e o fluoróforo estiver localizado no interior da macromolécula, nenhuma supressão estática poderá ocorrer. Por esta razão a supressão de fluorescência pode ser usada para localizar fluoróforos em proteínas e membranas, e a acessibilidade do fluoróforo ao supressor. 


\section{4}

\section{Ressonância paramagnética eletrônica (RPE): princípios básicos}

De entre os diversos autores descrevendo os princípios básicos desta técnica, o texto de Swartz et al., 1972; foi escolhido para explicar esses conceitos.

Assim como na maioria de técnicas de espectroscopia, o campo de radiação interage com os elétrons, causando mudanças na energia. No caso do RPE é o campo magnético que vai atuar sobre os dipolos magnéticos.

A energia necessária para ocorrer transição entre os estados de energia de uma molécula é absorvida em forma de fóton $h v$, onde $h$ é a constante de Planck e $v$ é a frequência do fóton. Para que a absorção ocorra, duas condições deveriam ocorrer:

O pacote de energia contida no quantum de luz (fóton) deve corresponder à separação de níveis de energia ( $\Delta E$ ) entre as quais a transição ocorre, isto é:

$$
h v=\Delta E
$$

Esta condição é conhecida como "condição de ressonância".

A componente elétrica (ou magnética) da radiação eletromagnética deve ser capaz de estimular dipolos elétricos (ou magnéticos) em uma molécula. Se isso acontece podemos dizer que a transição é "permitida".

Dipolos magnéticos são usualmente caracterizados por seu momento de dipolo magnético $\vec{\mu}$, caracterizado em termos da sua interação com um campo magnético externo $\vec{B}$. A energia de interação $E$ entre $\vec{\mu}$ e $\vec{B}$ é dada por:

$$
E=-\vec{\mu} \cdot \vec{B}=-\mu B \cos \theta=-\mu_{Z} B
$$

Onde $\mu_{z}$ é a projeção de $\vec{\mu}$ ao longo do eixo z, ou seja, na direção do campo magnético externo. $\mathrm{O}$ argumento $\theta$ representa o ângulo entre o campo magnético e o momento de dipolo magnético.

Todos os elétrons possuem um spin intrínseco, caracterizado pelo momento angular de spin $\vec{S}$, e momento magnético $\vec{\mu}$ proporcional ao spin. A relação entre estas duas grandezas está dada por:

$$
\vec{\mu}=\gamma \vec{S}
$$

onde $\gamma$ é o fator giromagnético. 
Pelos conceitos de mecânica quântica, a componente do spin do elétron ao longo de uma determinada direção pode ter apenas dois valores. Se $S_{Z}$ é essa componente, então:

$$
S_{Z}=\frac{h}{2 \pi} M_{S}=\hbar M_{S}
$$

onde $M_{S}= \pm 1 / 2$ é chamado de número quântico de spin. No movimento clássico:

$$
\gamma=-\frac{e}{2 m c}
$$

com $e$ : carga do elétron, $m$ : massa do elétron, $c$ : velocidade da luz. Reescrevendo a equação (2.15), temos que as energias dos momentos magnéticos de spin do elétron num campo magnético B é dada por:

$$
E=g \beta B M_{S}= \pm \frac{1}{2} g \beta B
$$

onde $\beta=e \hbar / 2 m c$ é chamado de magneton de Bohr, e $\mathrm{g}=2,00232$ é o fator g para o elétron livre. Essas energias $E$ são mostradas como uma função do campo magnético na Fig. 2.4. O desdobramento dos níveis de energia do elétron num campo magnético é chamado efeito Zeeman.

Aqui é conveniente dizer que apenas espécies contendo elétrons desemparelhados irão exibir um espectro de RPE. A quantização do momento angular de spin do elétron leva apenas a dois valores para $\mu_{Z}$. Dessa forma os elétrons poderão ocupar um determinado orbital aos pares, e poderão se acomodar se os seus momentos magnéticos de spin forem opostos, obedecendo ao Princípio de exclusão de Pauli. Pelo cancelamento de momento magnético eletrônico para cada par de elétrons, apenas aquelas moléculas contendo elétrons desemparelhados poderão ter momento magnético total não nulo, detectável por RPE.

Da condição de ressonância (Eq. 2.14), se a amostra é irradiada com certa radiação eletromagnética de frequência fixa $v$, existirá um campo magnético $B_{r}$ (campo de ressonância) no qual a ocorrerá absorção. Esta condição de ressonância é:

$$
h v=\Delta E=g \beta B_{r}
$$

Então, esta energia faz com que o momento magnético sofra uma transição de uma posição paralela ao campo magnético $B_{r}$ para uma posição antiparalela. A energia $\Delta E$ normalmente é fornecida através da exposição do sistema a um campo 
magnético de micro-ondas com frequência fixa, perpendicular ao campo magnético externo $B$, que é variado até que ocorra a transição. Quando isto acontecer, em $B=B_{r}$ (Eq. 2.20), o sistema absorve energia do campo de micro-ondas, e essa absorção, ou normalmente sua derivada, pode ser detectada por um sistema eletrônico adequado que forma parte dos equipamentos de RPE (Fig. 2.4).

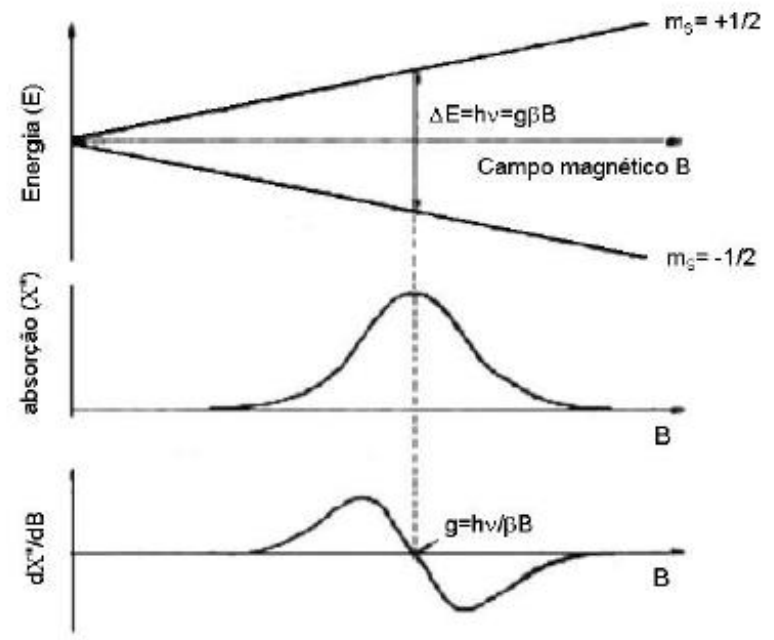

Figura 2.4. Desdobramento dos níveis de energia do spin eletrônico na presença de um campo magnético externo $\mathrm{B}$, a curva de absorção de energia do campo de micro-onda e sua derivada. (Modificado de Baffa, 1984)

Nem todos os casos possuem esse nível de simplicidade dos espectros. $\mathrm{Na}$ maioria de casos, o spin resultante toma valores diferentes de $1 / 2$, além de estar rodeado por cargas elétricas e momentos magnéticos nucleares. A interação do spin eletrônico com momentos magnéticos nucleares conduz à interação magnética hiperfina.

\section{O fator $\mathrm{g}$}

O fator g na Eq. 2.20 é uma constante universal e característica do elétron livre $\left(\mathrm{g}_{\mathrm{e}}=2,0023\right)$, considerando que $B_{r}$ é o campo magnético sobre o elétron.

No entanto, a aplicação de um campo magnético externo, pode gerar um campo magnético interno na amostra que irá ser subtraído ou adicionado ao campo externo. Por conveniência, $B_{r}$ na Eq. 2.20 será definido como o campo magnético externo de ressonância, e o fator $g$ "efetivo" será:

$$
g=\frac{h v}{\beta B_{r}}
$$


O fator $g$, deste modo, muda em relação ao $g$ do elétron livre, de acordo com as interações vizinhas, e pode refletir as características da molécula na qual elétrons desemparelhados estão presentes. A medida do fator $g$ para um sinal desconhecido pode ser importante para auxiliar na identificação da origem deste sinal. Por exemplo, para complexos de $\mathrm{Cu}^{2+}$ o $g$ está na faixa de 2,0 - 2,4, já para os complexos de $\mathrm{Fe}^{3+}$ o $g$ está na faixa de 1,4-3,1 (spin-baixo) ou 2,0 a 9,7 (spin-alto) [Swartz et al., 1972, pág. 24].

A principal origem dos campos magnéticos locais, que desviam o valor de $g$ em relação a $g_{e}$, é o momento magnético orbital, introduzido por uma mistura de estados excitados no estado fundamental.

Para a maioria das moléculas, a mistura de estados excitados é não isotrópica (anisotrópica), ou seja, desvios do fator $g$ em relação a $g_{e}$ dependem da orientação da molécula em relação ao campo magnético externo. A anisotropia do fator $g$ é geralmente reduzida à forma de um tensor de segunda ordem. Se o tensor é simétrico $\left(\mathrm{g}_{\mathrm{xy}}=\mathrm{g}_{\mathrm{yx}}, \mathrm{g}_{\mathrm{yz}}=\mathrm{g}_{\mathrm{zy}}\right.$, etc. $)$, este deve conter seis elementos independentes. Porém, muitas vezes existe um sistema de eixos principais $\mathrm{X}, \mathrm{Y}, \mathrm{Z}$ no qual o tensor g contém somente elementos diagonais:

$$
g_{\text {diagonal }}=\left[\begin{array}{ccc}
g_{x x} & 0 & 0 \\
0 & g_{y y} & 0 \\
0 & 0 & g_{z z}
\end{array}\right]
$$

Os elementos de $g_{\text {diagonal }}$ são conhecidos como valores principais do tensor g. Se X,Y,Z são equivalentes como em um octaedro, tetraedro ou simplesmente em um cubo, então $g_{x x}=g_{y y}=g_{z z}$.

Se o sistema tem simetria axial $\left(g_{x x}=g_{y y} \neq g_{z z}\right.$ ) é comum designar os fatores $g$ como $g_{/ /}$, paralelo ao eixo de simetria, e $g_{\perp}$, para o fator g perpendicular ao eixo de simetria $\left(g_{/ /}=g_{z z}\right.$ e $\left.g_{\perp}=g_{y y}=g_{x x}\right)$.

Para moléculas que não possuem simetria axial, isto é, simetria diferentes ( $g_{x x} \neq g_{y y} \neq g_{z z}$ ), cada fator principal é chamado de $\mathrm{g}_{1}$, $\mathrm{g}_{2}$ e $\mathrm{g}_{3}$ para os eixos $X, Y$ e $Z$.

$\mathrm{Na}$ maioria das situações biológicas, em que as entidades paramagnéticas são orientadas aleatoriamente, o espectro representará a média de todos os valores possíveis de $\mathrm{Br}$ (solução pouco viscosa, movimento rápido) ou a superposição de todos os valores possíveis de $\mathrm{Br}$, correspondentes a todas as orientações possíveis (espectro de pó ou de solução congelada). 


\section{3}

\section{Quinolonas e fluorquinolonas}

As quinolonas são um grupo de antibióticos sintéticos de amplo espectro com um alto efeito bactericida, boa absorção e excelente biodisponibilidade [Appelbaum et al., 2000]. O desenvolvimento das quinolonas começou com a descoberta do ácido nalidíxico, introduzido em terapia em 1960, durante a síntese e a purificação de um agente contra a malária (cloroquina) [Lesher et al., 1962]. Com isto se deu início a primeira geração das quinolonas

No entanto, o uso clínico do ácido nalidíxico foi limitado pelo seu espectro de atividade restrito. Foram feitas várias modificações no núcleo base, de modo a ampliar o espectro antibacteriano e para melhorar as propriedades farmacocinéticas.

Os compostos de segunda geração surgiram na década de 80 devido a duas modificações importantes, dentre várias: a introdução de um radical anel piperazina ou outro N-heterociclo na posição 7, e a introdução de um átomo de flúor na posição 6. Com estas modificações da estrutura, o espectro de ação das quinolonas aumentou consideravelmente, dando origem a uma nova classe: as fluorquinolonas.

Com base nas propriedades bactericidas e farmacocinéticas, as quinolonas são classificadas em 4 gerações [Oliphant e Green, 2002; King et al., 2000, Zhanel et al., 1999]. A Tabela 3.1 apresenta algumas destas quinolonas e fluorquinolonas com suas indicações clínicas. 
Tabela 3.1 - Principais quinolonas de cada geração com suas indicações clínicas.

\begin{tabular}{|c|c|c|}
\hline Geração & Quinolonas & Indicações clínicas \\
\hline Primeira & $\begin{array}{c}\text { Ácido Nalidíxico } \\
\text { Cinoxacina }\end{array}$ & Infecções no trato urinário \\
\hline Segunda & $\begin{array}{c}\text { Norfloxacina } \\
\text { Ciprofloxacina } \\
\text { Ofloxacina } \\
\text { Levofloxacina } \\
\text { Pefloxacina }\end{array}$ & $\begin{array}{l}\text { Infecções no trato urinário, infecções } \\
\text { respiratórias, infecções gastro-intestinais, } \\
\text { inflamação nos rins, infecções } \\
\text { ginecológicas, doenças sexualmente } \\
\text { transmissíveis, prostatites, infecções } \\
\text { oculares, na pele e em tecidos }\end{array}$ \\
\hline Terceira & $\begin{array}{l}\text { Sparfloxacina } \\
\text { Gatifloxacina }\end{array}$ & Pneumonia e bronquite crônica \\
\hline Quarta & $\begin{array}{l}\text { Moxifloxacina } \\
\text { Trovafloxacina }\end{array}$ & Todas as indicações anteriores \\
\hline
\end{tabular}

As FQs são agentes bactericidas que atuam inibindo a replicação e transcrição do DNA bacteriano, causando rapidamente a morte celular [Cozzarelli, 1980; Mitscher 2005]. Elas inibem duas enzimas bacterianas chaves, DNA-girase (topoisomerase II) e DNA topoisomerase IV. As quinolonas interagem com o complexo DNA-enzima, formando um complexo DNA-enzima-fármaco que bloqueia a progressão e o processo de replicação [Hooper, 2000; Maxwell, 1992]

Dentre as várias FQs temos como as mais utilizadas a ciprofloxacina, norfloxacina, ofloxacina, levofloxacina, esparfloxacina, entre outras. Vamos iniciar nosso estudo com a norfloxacina, pois já vem sendo estudada em nossos laboratórios, mas em alguns casos ampliaremos o estudo com a utilização de ciprofloxacina e levofloxacina.

\section{Norfloxacina}

A norfloxacina, patenteada em 1978, foi o primeiro tipo de fluorquinolona a ser sintetizada com potente ação antibacteriana por administração oral. Durante anos vem sendo utilizada eficazmente em seres humanos e animais no tratamento de diversas infeções [Song et al., 2005]. Este fármaco tem massa molar 319,99 $\mathrm{g} \mathrm{mol}^{-1}$ e apresenta duas constantes de dissociação $\mathrm{pK}_{\mathrm{a} 1}=6,34$ e $\mathrm{pK}_{\mathrm{a} 2}=8,75$ correspondentes à dissociação do grupo carboxílico e amina do anel piperazina, 
respectivamente [Barbosa et al., 1997; O’Neil, 2006; Esponda et al., 2009]. Sua estrutura aparece na Fig. 3.1.<smiles>CCn1cc(C(=O)O[Na])c(=O)c2cc(F)c(N3CCN(C(C)(C)C)CC3)cc21</smiles>

Figura 3.1. Estrutura representativa de norfloxacina (1-ethyl-6-fluoro-1,4-dihydro-4-oxo-7-(1piperazinyl)-3-quinolinecarboxylic acid, NFX), indicando os pKa para o grupo amina da piperazina e o grupo ácido.

Assim, como várias outras FQs, a NFX possui dois grupos funcionais aceitadores de prótons que correspondem a dois equilíbrios químicos de ionização. O grupo carboxílico (posição 3) protona-se em meio ácido. O grupo associado ao $\mathrm{N}_{4}$ do anel piperazina (posição 7) desprotona-se em meio alcalino [Drakopoulos e Ioannou, 1997]. Dependendo do pH do meio, as FQs podem existir em três formas: catiônica $\mathrm{H}_{2}-(\mathrm{FQs})^{+}$em meio ácido, neutra ou zwitteriônica: $\mathrm{H}-(\mathrm{FQs})^{ \pm}$em meio neutro ou fracamente ácido, e aniônica: (FQs) ${ }^{-}$em meio alcalino (Fig. 3.2). Em vista disso, sua interação com outras moléculas depende fortemente do $\mathrm{pH}$ do meio, da força iônica e da distribuição de cargas dos sistemas.

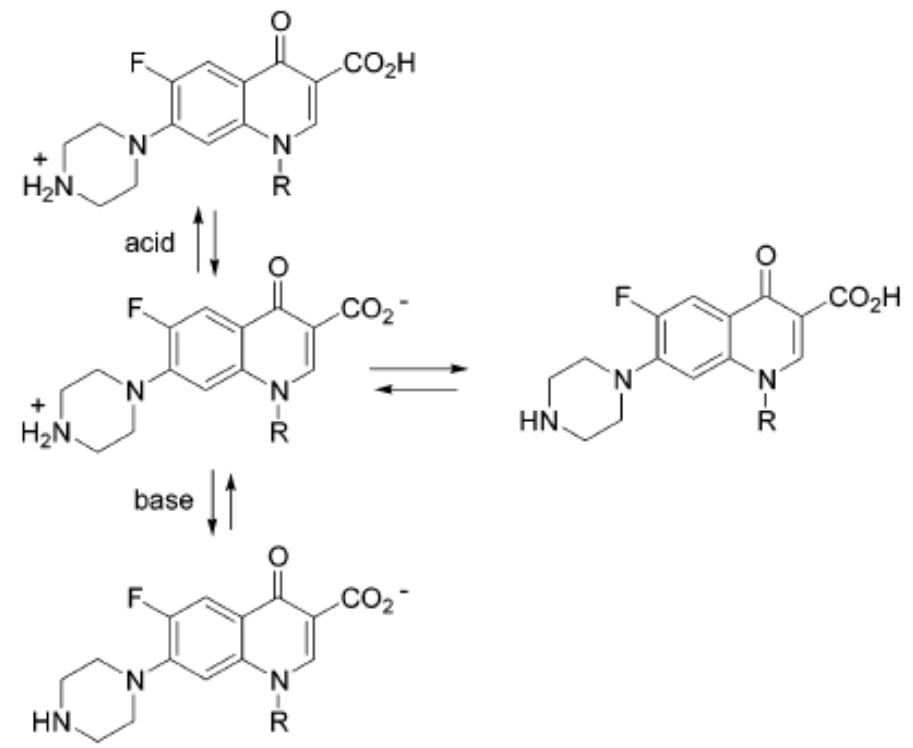

Figura 3.2. Estrutura representativa do equilíbrio químico de ionização da NFX, nos meios (a) ácido, (b) neutro e (c) alcalino [Mitscher, 2005]. 


\section{Complexação das fluorquinolonas a metais e a sua importância.}

A microespeciação das $\mathrm{FQs} \mathrm{é} \mathrm{importante} \mathrm{na} \mathrm{formação} \mathrm{de} \mathrm{complexos}$ metálicos: moléculas de fluorquinolona atuam como ligantes em meio básico na forma desprotonada $(F Q s)^{-}$e na forma zwitteriônica $(F Q s) H^{ \pm}$se o meio for neutro ou fracamente ácido/básico. Em condições fortemente ácidas, as quinolonas formam complexos iônicos em sua forma catiônica $(F Q s) H_{2}^{+}$.

FQs formam complexos metálicos devido à sua capacidade de ligar íons de metal. Para entender melhor esta ligação das FQs nos seus complexos metálicos, mostramos na Fig. 3.3 os principais modos de coordenação. Nesses complexos metálicos, as FQs podem se coordenar como ligante bidentado, monodentado. Frequentemente, as quinolonas são coordenadas de uma forma bidentada, através de um dos átomos de oxigênio do grupo carboxílico desprotonado e o átomo de oxigênio da carbonila (Fig. 3.3 (a)). Algumas vezes podem atuar como ligante bidentado coordenado através de dois átomos de oxigênio carboxílico (Fig. 3.3 (b)) ou através de ambos os átomos de nitrogênio da piperazina (Fig. 3.3 (c)). As quinolonas também podem formar complexos como ligantes unidentados coordenados ao íon metálico por meio do nitrogênio terminal do grupo piperazínico (Fig. 3.3 (d)). Em condições fortemente ácidas, as quinolonas são protonadas e aparecem como cátions nos complexos iônicos.

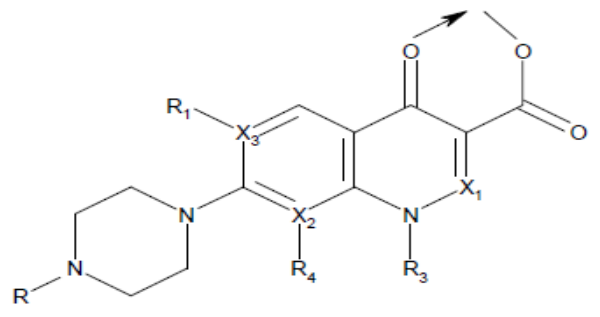

(a)

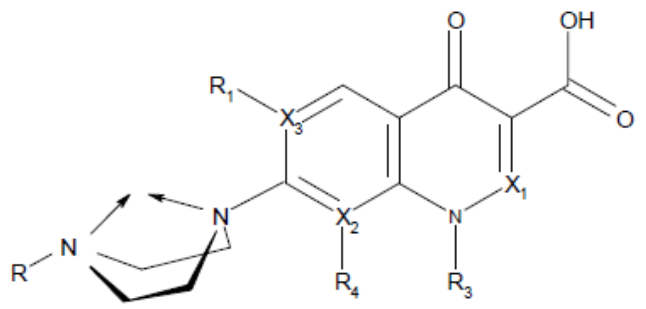

(c)

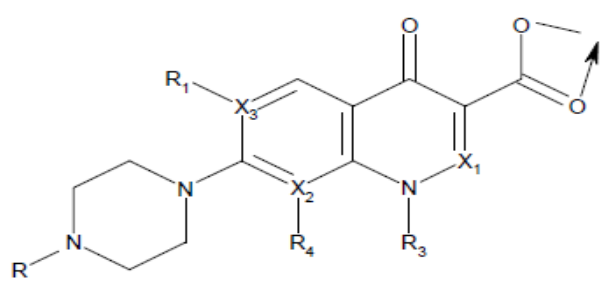

(b)

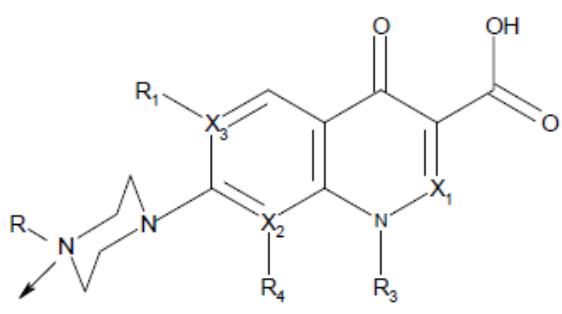

(d)

Figura 3.3. Principais modos de coordenação das quinolonas [Uivarosi, 2013].

As quinolonas podem ligar cátions divalentes $\left(\mathrm{Mg}^{2+}, \mathrm{Ca}^{2+}, \mathrm{Cu}^{2+}, \mathrm{Zn}^{2+}, \mathrm{Fe}^{2+}\right.$, etc.), que formam quelatos com estequiometria 1:1 ou 1:2 (metal:ligante) ou cátions 
trivalentes $\left(\mathrm{A}^{3+}, \mathrm{Fe}^{3+}\right)$, que formam quelatos com estequiometria 1:1, 1:2 ou 1:3. Na Fig. 3.4 está representada a estrutura geral dos quelatos de quinolonas com cátions divalentes na razão molar 1:2. Em um estudo de sistema $\mathrm{Cu}(\mathrm{II})$ ciprofloxacina se observou que o número de ligantes coordenados depende do $\mathrm{pH}$, na região ácida, a formação 1:1 é favorável, em meio básico a formação do complexo 1:2 é mais favorável [Turel et al., 1996].

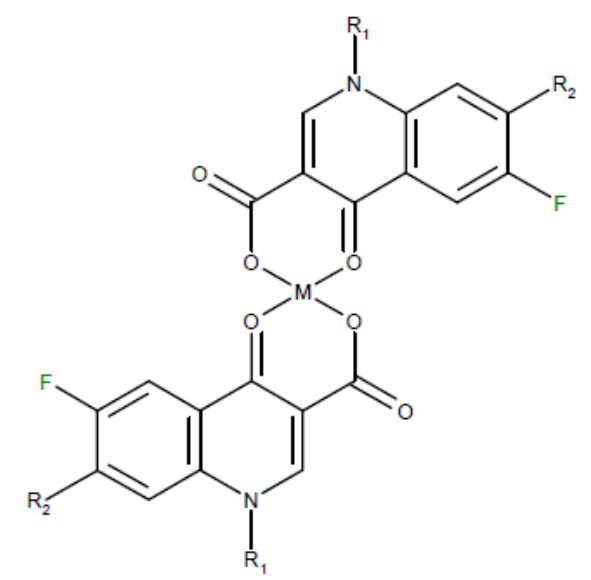

Figura 3.4. Estrutura geral do quelato de quinolona 1:2 (metal: ligante) com cátions divalentes (Adaptado de Uivarosi, 2013).

Diversos estudos têm mostrado como a formação dos complexos com cátions altera a biodisponibilidade e a penetração celular das quinolonas, alterando significativamente as propriedades óticas das FQs, dependendo do tipo de cátion e do grau de ionização da fluorquinolona [Köpf-Maier, 1994]. Em uma revisão bastante abrangente, Psomas et al., 2013 apresentaram as estruturas e a atividade biológica dos complexos de algumas FQs com $\mathrm{Cu}(\mathrm{II}), \mathrm{Ni}(\mathrm{II}), \mathrm{Co}(\mathrm{II})$ e $\mathrm{Zn}$ (II); e analisaram a influência do segundo ligante na atividade biológica.

Muitos outros fatores devem ser considerados para os complexos de metal com atividade antimicrobiana, tais como a natureza do íon metálico, a natureza dos ligantes, o efeito quelato, a carga total do complexo, a natureza do contra íon do complexo iônico, e a nuclearidade do metal central do complexo [Uivarosi, 2013]. Complexos com estequiometria 1:1 de levofloxacina com $\mathrm{Cr}(\mathrm{III}), \mathrm{Fe}(\mathrm{III}), \mathrm{Cu}$ (III) etc. têm demonstrado um efeito antifúngico maior do que o ligante livre [Abd ElHalim et al., 2011; Sultana et al., 2010]. 
Foram também sintetizados complexos organometálicos de rutênio com algumas FQs [Turel et al., 2010] que mostraram interação com DNA e são moderadamente ativos contra Trypanosoma brucei rhodesiense, Trypanosoma cruzi e Plasmodium falciparum.

A atividade das FQs contra o câncer tem sido explorada [Herold et al., 2002; Sissi et al., 2003; Thadepalli et al., 2005; Ahmed et al., 2012] com base na sua capacidade de bloquear a enzima topoisomerase II, inibindo assim a atividade de reparação do DNA. Não é surpreendente que numerosos estudos sobre a atividade biológica de complexos metálicos de FQs incluam a sua capacidade de interagir com o DNA, como uma premissa contra o câncer.

\section{1}

\section{Quinolonas e sua interação com alvos biológicos}

Estudos da interação das FQs assim como dos seus complexos metálicos com as albuminas séricas bovina (BSA) e humana (HSA), e com DNA, foram relatados [Jayabharathi et al., 2012; Kamat, 2005]. A albumina sérica possui capacidade de se ligar reversivelmente a uma grande variedade de fármacos, transportando inúmeras substâncias através do sangue [Góes, 2005]. A interação das FQs e seus complexos metálicos com estas proteínas pode ser avaliada mediante mudanças na fluorescência intrínseca [Lakowicz, 2006].

A capacidade de ligação dos complexos de FQs com o DNA também tem sido foi estudada. Os modos de interação com o DNA podem ser avaliados através de titulações espectrofotométricas de absorção na região do ultravioleta-visível (UVVis). Assim se pode medir a intensidade da interação fármaco-proteína e identificar o modo de interação [Paraginski, 2007]. A interação com o DNA foi investigada in vitro utilizando diferentes associações entre quinolonas e íons de metais bivalentes [Song et al., 2005; Drevenšek et al., 2003; Guo et al., 2011; Robles et al., 2000]. Quando ocorre interação eletrostática ou intercalação fármaco-DNA, observa-se diminuição da absortividade molar, e/ou um desvio para a região do vermelho da banda de absorção do composto (hipocromismo e batocromismo, respectivamente). Já quando a estrutura secundária do DNA é quebrada, observa-se um aumento da absortividade molar e/ou um desvio para a região do azul (hipercromismo e hipsocromismo, respectivamente) [Paraginski, 2007; Firdaus et al., 2008]. 


\subsection{1}

\section{Membranas biológicas}

\section{Surfactantes, micelas e lipossomas}

Os lipídeos são biomoléculas apenas solúveis em solventes orgânicos. Têm como funções: alimento energético, armazenamento de energia, moléculas sinalizadoras, componentes estruturais de membranas. Os principais tipos de lipídeos são os triglicerídeos (gorduras e óleos), fosfolipídeos, ceras e esteroides

Detergentes ou surfactantes, assim como lipídios, são moléculas anfifílicas, isto é, moléculas que possuem duplo caráter, com uma região hidrofóbica e outra hidrofílica. Elas podem se autoassociar formando uma variedade de estruturas, como micelas (vesículas esféricas ou cilíndricas, com um interior hidrofóbico), lipossomas (vesículas com interior aquoso), microtúbulos, microemulsões, etc (Fig. 3.5). O tamanho dessas estruturas varia de $0,1 \mathrm{~nm}$ a $1 \mu \mathrm{m}$. A associação das moléculas de surfactantes ocorre por interação de natureza entrópica, denominada interação hidrofóbica.

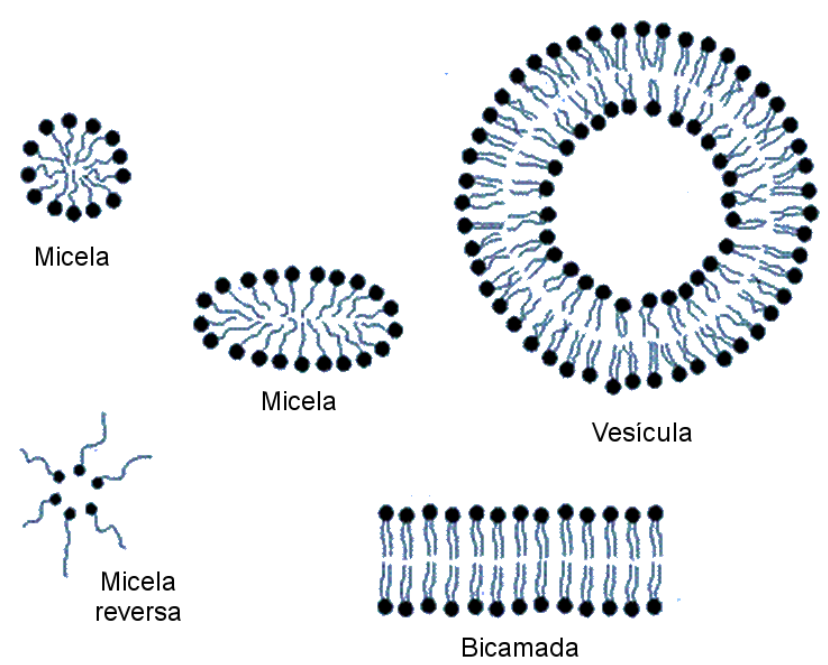

Figura 3.5. Estruturas formadas por auto-agregação de surfactantes e lipídios (modificado de http://people.umass.edu/mcclemen/Group.html).

A formação das micelas, chamada de micelização, começa a partir de uma concentração mínima chamada concentração micelar crítica, CMC (Fig. 3.6). 


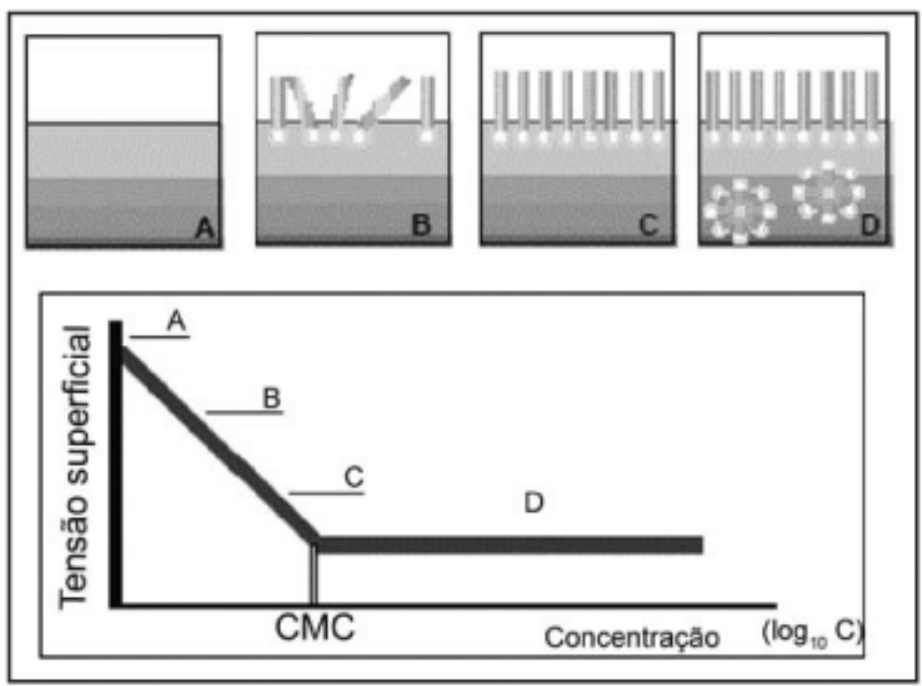

Figura 3.6. Distribuição de surfactante em solução aquosa. Efeito na tensão superficial e formação de micelas.

\section{Lipossomas}

Lipossomas são vesículas de fosfolipídios e colesterol. Podem ser unilamelares (Fig. 3.7) ou multilamelares, e permitem incorporar drogas hidrofílicas e hidrofóbicas em sua matriz, podendo ser utilizados para transporte de diversos fármacos e biomoléculas. As estruturas mais simples e conhecidas, como esquematizada na Fig. 3.7, consistem em uma membrana formada por uma dupla camada de fosfolipídios, estes podem apresentar uma ou duas longas cadeias hidrocarbonadas apolares ligadas a uma extremidade polar (cabeça) contendo um grupo fosfato. Esta membrana, por sua vez, forma uma esfera que normalmente contém um líquido polar no seu interior, e que pode ser o mesmo líquido onde a esfera está dispersa.

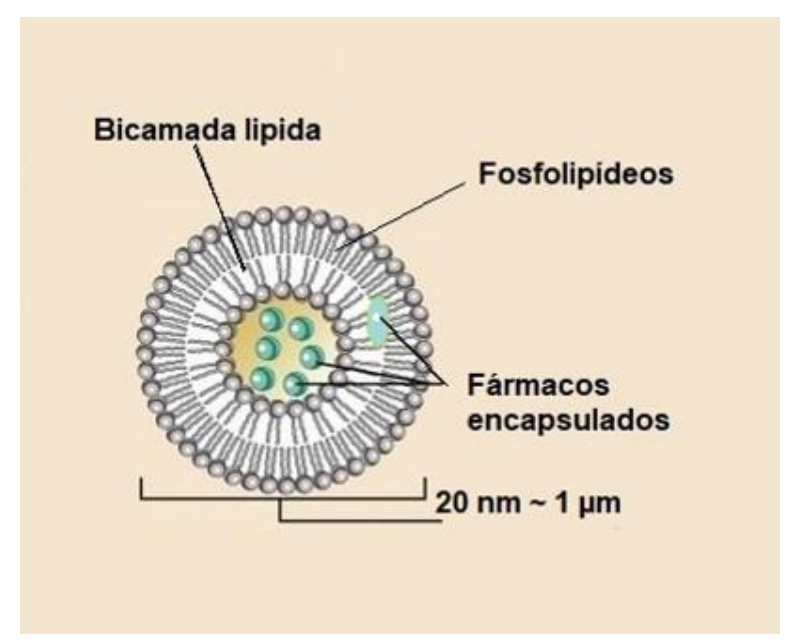

Figura 3.7. Esquema de distribuição de fármacos dentro de um lipossoma unilamelar. 
Dos diversos tipos de lipossomas que existem, podemos classificar como segue:

- Lipossomas unilamelares pequenos (SUV): aqui a membrana é formada por uma única bicamada fosfolipídica, cujo tamanho da membrana varia entre 20 e $80 \mathrm{~nm}$.

- Lipossomas unilamelares grandes (LUV): aqui a membrana é formada por uma única bicamada fosfolipídica, com diâmetro variando entre $80 \mathrm{~nm}$ e $1 \mu \mathrm{m}$.

- $\quad$ Lipossomas multilamelares (MLV): aqui a membrana é formada por várias bicamadas fosfolipídicas dispostas de forma concêntrica; com diâmetro externo variando entre $400 \mathrm{~nm}$ e alguns micrômetros.

- Lipossomas multivesiculares (MVL), semelhantes em forma às MLVs, porém com bicamadas não concêntricas, o que torna a vesícula uma estrutura mais complexa, inclusive as vezes com membranas bastante curvadas, normalmente são estruturas mal formadas nos processos de obtenção dos outros tipos; com diâmetro variando também entre $400 \mathrm{~nm}$ e alguns micrômetros.

- $\quad$ Lipossomas gigantes $(\mathrm{GV})$, normalmente formadas por uma única bicamada fosfolipídica, sendo assim designados como lipossomas unilamelares gigantes (GUV). O tamanho dessas membranas é superior a $1 \mu \mathrm{m}$, podendo chegar a dezenas de micrômetros.

Por outro lado, investigações referentes ao uso de sistemas lipossomais com FQs mostram uma diminuição na fototoxicidade de FQs ao diminuir a concentração a ser administrada. Também, se administrados por via intravenosa, lipossomas conseguem entregar o fármaco preferencialmente nos mesmos locais de infeção, devido ao aumento da captura dessas vesículas pelos macrófagos provenientes do sistema reticuloendotelial [Hooper, 1998]. Outra vantagem é o uso de fármacos de baixa solubilidade em $\mathrm{pH}$ 7, incorporando o mesmo dentro dos lipossomas, devido a que não é possível a aplicação do fármaco em uso parenteral. [Vries e Henegouwen, 2000; Sacheteli et al., 2000].

Majumdar et al., 1992 descreveram o comportamento de CFX incorporada em lipossomas para o tratamento de infeções causadas por uma bactéria (MAC) que 
frequentemente causa infeções oportunistas em pacientes com AIDS, mostrando que o antibiótico incorporado foi 50 vezes mais eficiente que ao utilizar o fármaco livre [Duzgunes et al., 1996; Koletar, 1997]

De acordo com Nagata et al., 1999; os resultados obtidos para CFX incorporada em lipossomas induziram ao aumento das funções dos macrófagos, da produção de óxido nítrico e de citocinas, portanto esses estudos podem também ser estendidos para trabalhos com outras fluoroquinolonas em terapias antimicrobianas, câncer e AIDS.

\subsection{2}

\section{Nanopartículas metálicas e sua interação com fluorquinolonas}

Nanopartículas de metais nobres têm sido o centro de atenção de alguns estudos interessantes até a atualidade devido às suas propriedades óticas únicas, surgindo da ressonância de plasmon superficial (SPR). Entre essas nanopartículas, o ouro e a prata são considerados bem interessantes devido a que a sua banda de ressonância plasmônica está localizada na região visível do espectro eletromagnético e as mudanças nessa banda quando interagem com outras moléculas podem ser bem observada [Jain et al., 2008].

Nanopartículas de ouro (AuNPs) com nanoestruturas bem definidas têm sido empregadas para diversas aplicações nas áreas das ciências físicas, químicas e bioquímicas. A riqueza das suas propriedades únicas as tornam particularmente adequadas para aplicações em campos que abrangem optoeletrônica, catálise química, entrega controlada de drogas, entre outros [Fedlheim e Foss, 2001]. Os conjugados de AuNPs com antibióticos e anticorpos também têm sido utilizados para induzir a morte seletiva de protozoários e bactérias [Pissuwan et al., 2007; Huang et al., 2007; Zharov et al., 2006]. Em relação à atividade antibacteriana, Williams et al., 2006, mostraram que as próprias nanopartículas de ouro não afetam o crescimento bacteriano ou a atividade funcional, mas conjugados de vancomicina com AuNPs provocaram inibição do crescimento de bactérias patogênicas [Huang et al., 2007]. Gu et al., 2003 sintetizaram AuNPs estáveis cobertas com vancomicina e mostraram o aumento significativo da atividade antibacteriana para este conjugado, em comparação com a atividade do antibiótico livre. Um resultado 
semelhante foi relatado com ciprofloxacina conjugada com nanopartículas coreshell de $\mathrm{Au} / \mathrm{SiO}_{2}$ [Rosemary et al., 2006].

\section{Ablação a laser pulsado}

Ablação a laser pulsado em meios líquidos é uma técnica fácil, versátil e limpa que envolve processos físicos complexos na síntese de diversas nanopartículas metálicas em diversos solventes. Brevemente, a técnica consiste na irradiação de um alvo (ouro puro sólido), absorvendo fótons, os quais aquecem e foto-ionizam a área irradiada. Alguns outros componentes podem ser arrancados da superfície alvo, como vapores, gotas líquidas, fragmentos sólidos, mistura de íons metálicos, "contaminantes", formando um plasma na superfície do metal irradiado. A quantidade removida depende da energia absorvida. Por exemplo, para produzir $1 \mathrm{mg}$ de nanopartículas da maioria de materiais nobres, se requer $10^{5}$ pulsos de laser, correspondentes a uma ablação da ordem de 20 minutos trabalhando em 10 $\mathrm{Hz}$ (laser de nanossegundos ou picossegundos) [Amendola and Meneghetti, 2009]. A Fig. 3.8 mostra o esquema da técnica, consistindo num laser pulsado, um sistema de óptica de focalização e um recipiente contendo a placa do metal, o qual é colocado na proximidade do foco.

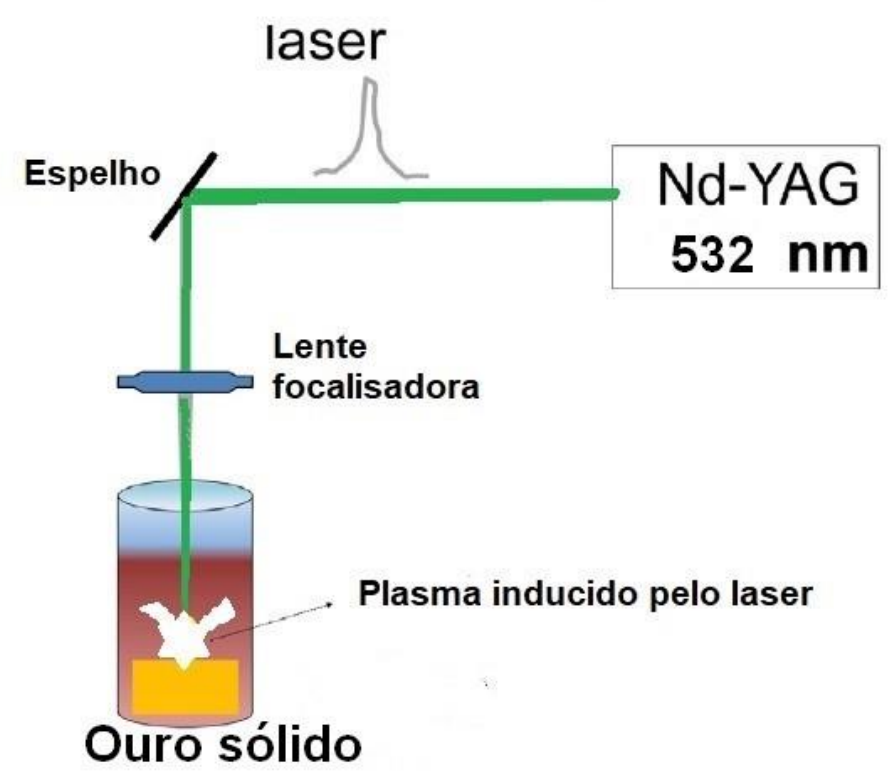

Figura 3.8. Representação esquemática do método de ablação a laser, mostrando os principais componentes (modificado de Palazzo et al., 2017). 
Em nosso caso, foram utilizadas nanopartículas de ouro sintetizadas por este método em água, mediante introdução de absorventes de $\mathrm{CO}_{2}$ na solução, formando AuNPs cobertas de oxocarbonos, que denominamos nanocompósitos (AuNCs). Esta camada de oxocarbonos é criada durante o processo de irradiação do laser sobre o ouro puro sólido, mostrando estabilidade constante durante meses sob condições adequadas [Del Rosso et al., 2016].

Existem diversas técnicas para a síntese de nanopartículas de ouro. Entre as mais utilizadas temos métodos químicos e físicos. Dentre os métodos físicos temos o processo de condensação de ouro, gradiente de temperaturas e ablação a laser. Entre os químicos o mais conhecido é o método de Turkevich, além de Brust e outros pesquisadores que desenvolveram diversas técnicas para controlar a forma e o diâmetro das partículas [Bonifácio, 2007]. Brevemente, o método de Turkevich se baseia na redução e estabilização das nanopartículas pelo íon citrato (Fig. 3.9).

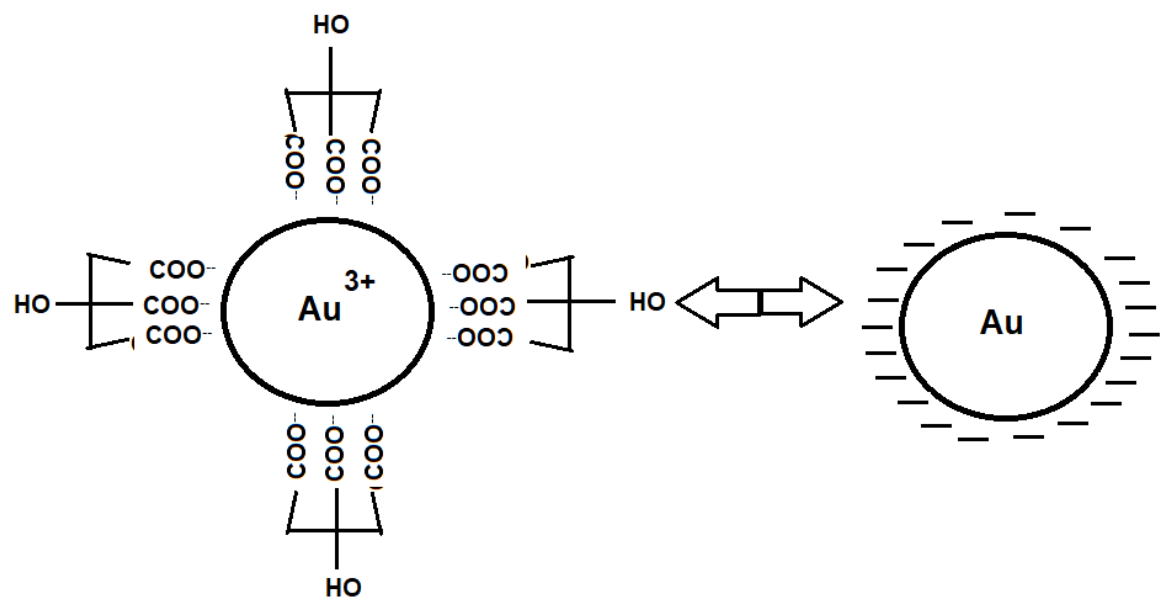

Figura 3.9. Representação esquemática de AuNPs produzida pelo método de Turkevich

Para que as AuNPs se mantenham estáveis e dispersas em suspensão aquosa é essencial a presença de uma camada estabilizante, afim de evitar a aglomeração [Turkevich et al., 1954]. Esta aglomeração é facilmente reconhecida pelo deslocamento da banda de plasmons para regiões de menor energia (comprimentos de onda maiores). Plasmons são oscilações dos elétrons na superfície de um metal, que apresentam energia quantizada, interferindo em propriedades eletrônicas e ópticas. Plasmons de superfície interferem na cor da solução aquosa das AuNPs, relacionada à energia de transição eletrônica, isto é, a cor depende da densidade dos estados eletrônicos e do tamanho das AuNPs. Dimensões entre 2 e $40 \mathrm{~nm}$ apresentam coloração vermelha, devido a transições entre as bandas eletrônicas que 
acomodam os elétrons superficiais. No entanto, tamanhos maiores apresentam uma coloração violeta devido ao aumento da densidade de estados eletrônicos e consequente diminuição da energia de transição entre as bandas (aumento do comprimento de onda).

Como já sabemos, a supressão de fluorescência é o processo no qual a intensidade de fluorescência de um fluoróforo diminui. Recentemente, devido ao seu alto coeficiente de extinção e às suas propriedades ópticas altamente dependentes da distância, AuNPs têm sido utilizadas como supressores por transferência de energia [Ghosh et al., 2012; Gao et al., 2011; Guo et al., 2011]. Quando os fluoróforos ou moléculas receptoras marcadas com fluoróforos interagem com AuNPs, a fluorescência será extinta através de transferência de energia e/ou processos de transferência de elétrons a partir dos fluoróforos para as AuNPs. Dois mecanismos são apresentados para explicar o processo de transferência de energia: transferência de energia superficial de nanopartículas (NSET) e fluorescência por transferência ressonante de energia (FRET). [Yun et al., 2005; Jennings et al., 2006; Jennings, Schlatterer et al., 2006; Ray et al., 2006]. Recuperação de fluorescência de uma molécula fluorescente ligada às AuNPs pode ser utilizada para sensoriamento de analitos por "turn-on” da fluorescência. Após a adição de um analito alvo, fluoróforos, ou moléculas receptoras marcadas com fluoróforos, são removidos da superfície das AuNPs. Como resultado, a intensidade de fluorescência dos fluoróforos aumenta com o incremento da concentração do analito [Darbha et al., 2007; Chen et al., 2009]. Ao tirar vantagem da forte capacidade desta supressão pelas AuNPs, muitos sensores de fluorescência eficientes foram desenvolvidos para o ensaio de moléculas biológicas e íons [Gao et al., 2011; Guo et al., 2011; Hormozi-Nezhad et al., 2013].

Considerando uma boa sobreposição entre o espectro de fluorescência das FQs e os espectros de absorção de AuNPs, os pares AuNPs-FQs podem ser escolhidos como um sistema de transferência de energia plausível.

A restauração de fluorescência de FQs pode ser realizada mediante adição de tióis, devido à forte interação entre os tióis e nanopartículas de ouro para formar ligações Au-S, o que leva à dissociação de FQs das superfícies das AuNPs [Amjadi e Farzampour, 2013].

Com tudo isto, é de vital importância o estudo das propriedades físicoquímicas das FQs e seus complexos metálicos para compreender e melhorar sua 
eficácia na aplicação farmacológica. As interações dos complexos em sistemas biológicos acarretam normalmente mudanças no espectro de fluorescência. Tais mudanças vão ajudar a conhecer o grau de dissociação do fármaco ante o alvo biológico. Em nosso estudo da interação de FQs e complexos metálicos com alvos biológicos são utilizadas diversas técnicas espectroscópicas: absorção UV-Visível, fluorescência estacionária e resolvida no tempo e ressonância de spin eletrônico. 
4

\section{Materiais e métodos}

\section{1}

\section{Materiais}

Como fármacos fluorescentes foram utilizadas as FQs norfloxacina (NFX), levofloxacina (LFX) e ciprofloxacina (CFX), obtidas de Sigma-Aldrich (Fig. 4.1 (a)).

O complexo dicloro(1,10-fenantrolina)cobre(II) (Cu:Phen) foi adquirido de Sigma-Aldrich e o dicloro(2, 2'-bipiridina)cobre(II) (Cu:Bipy) foi sintetizado pelo grupo da Prof. Letícia Teixeira, Departamento de Química da UFMG.

Fosfatidilcolina(L- $\alpha$-Phosphatidylcholine) de ovo, dodecil sulfato de sódio (SDS), brometo de cetiltrimetilamônio (CTAB), glutationa (GSH), ácido esteárico (SA) e DNA de timo de bezerro foram adquiridos de Sigma-Aldrich (Estruturas moleculares apresentadas na Fig. 4.2).

$\mathrm{O}$ tampão fosfato (PB) foi preparado com mistura dos sais $\mathrm{NaH}_{2} \mathrm{PO}_{4}$ e $\mathrm{Na}_{2} \mathrm{HPO}_{4}$, ajustando o pH em 7,4. O tampão fosfato salino isotônico foi preparado usando cloreto de sódio 0,15 M em PB $10 \mathrm{mM}, \mathrm{pH}$ 7,4. Foram preparadas soluções estoques de SDS 100 mM e NFX 1 mM em água.

Nanocompósitos de ouro, fornecidos pelo grupo do Prof. Tommaso Del Rosso [Del Rosso, 2016], foram sintetizados pela técnica de ablação a laser em água ultrapura ajustando-se o pH com $\mathrm{NaOH}$. Caracterização dos AuNCs

Os AuNCs foram caracterizados pelo grupo do professor Del Rosso, utilizando microscopia eletrônica de varredura por transmissão (STEM, do inglês scanning transmission electron microscope), obtendo a imagem das nanopartículas preparadas em $\mathrm{NaOH}$ (Fig. 4.3 (a)), revelando que a maioria destas nanopartículas tem um diâmetro médio em torno de $6 \mathrm{~nm}$. 


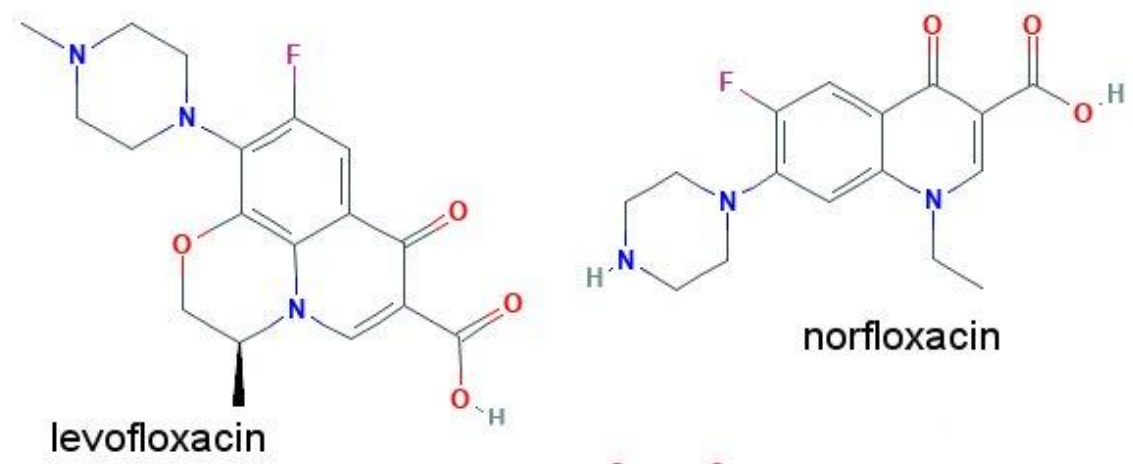

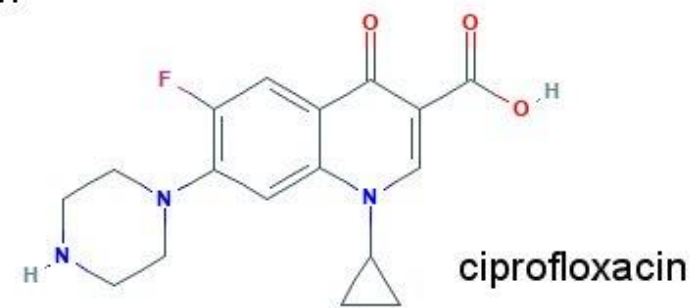

(a)

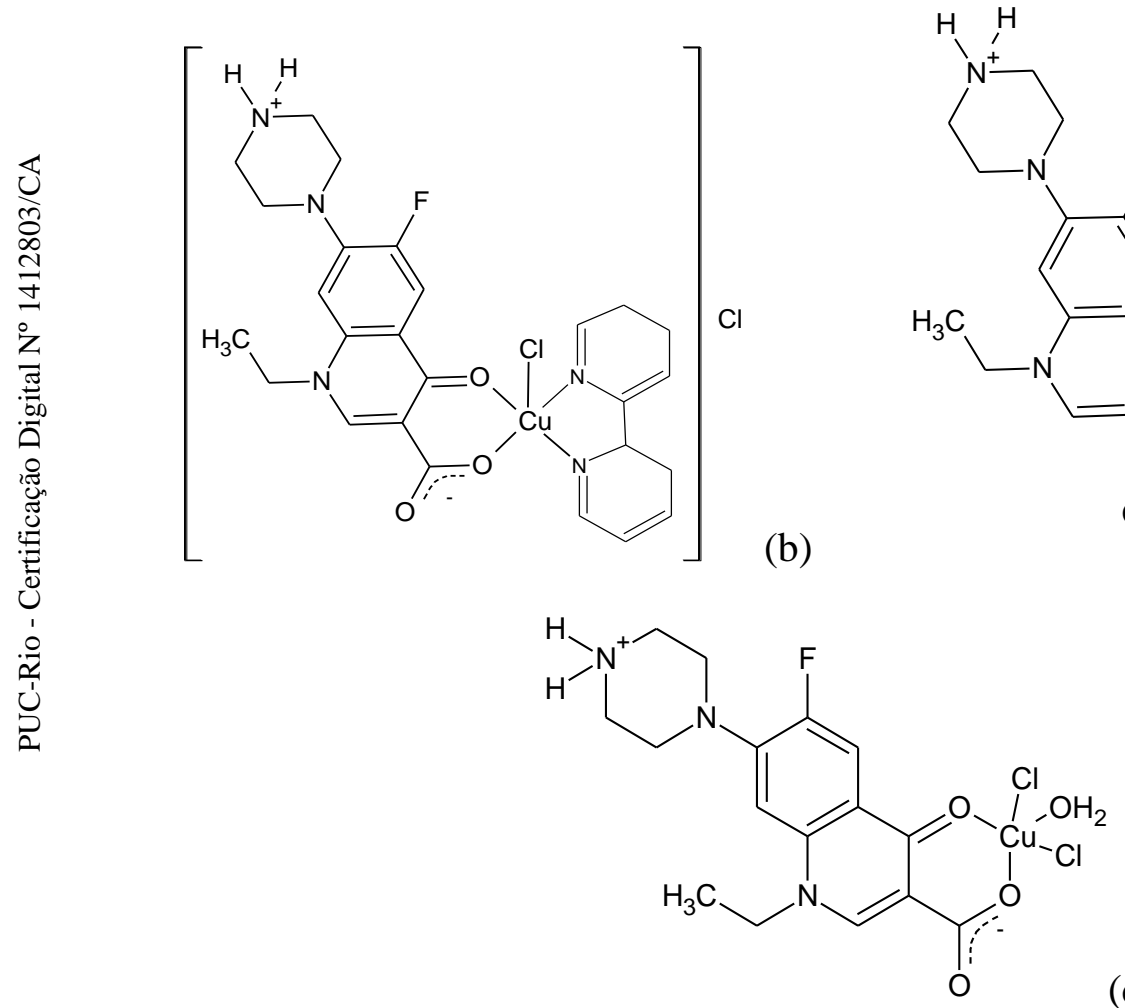

(d)

Figura 4.1. (a) Estruturas moleculares de levofloxacina, norfloxacina e ciprofloxacina. Estruturas propostas para os complexos de $\mathrm{Cu}(\mathrm{II})$ de norfloxacina: (b) [CuCl $2(\mathrm{Bipy})(\mathrm{NFX})] \mathrm{Cl}]$, (c) $\left[\mathrm{CuCl}_{2}(\mathrm{Phen})(\mathrm{NFX})\right]$, (d) $\left[\mathrm{CuCl}_{2}\left(\mathrm{H}_{2} \mathrm{O}\right)(\mathrm{NFX})\right]$. 
(a)<smiles>CCCCCCCCCCCCCCCCCCCCCCCC(=O)OC[C@H](O)COP(=O)(O)OCC[N+](C)(C)C</smiles>

(b)

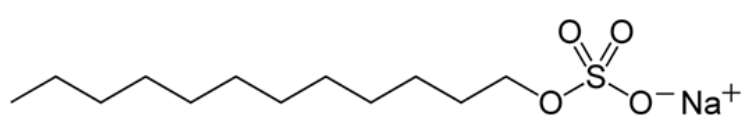

(c)

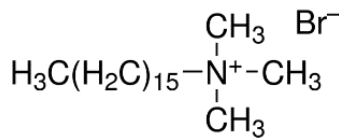

(d)<smiles>N[C@@H](CCC(=O)NC(CS)C(=O)NCC(=O)O)C(=O)O</smiles>

(e)

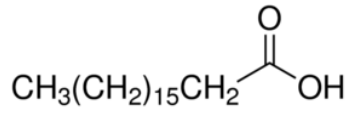

Figura 4.2. Estrutura molecular de (a) fosfatidilcolina de ovo (tamanho de cadeia variável), (b) dodecilsulfato de sódio (SDS), (c) brometo de cetiltrimetilamônio, (d) glutationa, (e) ácido esteárico

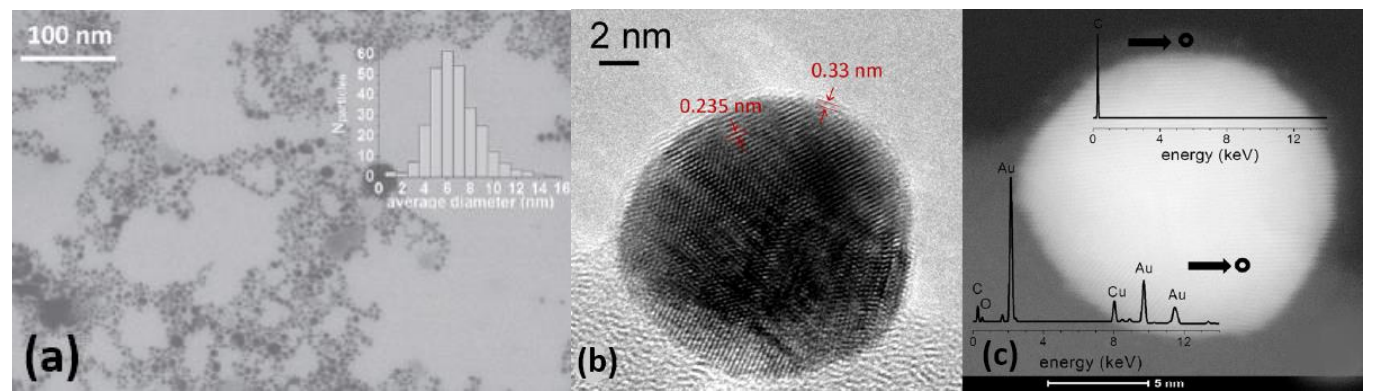

Figura 4.3. (a) Micrografia TSEM de AuNCs ajustando o pH do sistema de água com $\mathrm{NaOH}$. A inserção representa a distribuição estatística dos diâmetros das partículas. (b) Imagem HRTEM de um AuNC: o espaçamento de rede correspondendo a $\mathrm{Au}(0,235 \mathrm{~nm})$ e grafite $(0,330 \mathrm{~nm})$ claramente visível no núcleo e na superfície, respectivamente. (c) Imagem HRSTEM e análise elementar de EDX (Espectroscopia de raios X por dispersão em energia) do mesmo AuNC [Del Rosso, 2016]

Imagens de alta resolução e espectroscopia foram aplicadas pelo grupo do Del Rosso para obter provas diretas e claras da presença da rede complexa de carbono e oxocarbonos envolvendo os AuNCs. As Fig. 4.3 (b) e (c) mostram imagens típicas de HRTEM (High-resolution transmission electron microscopy) e HRSTEM (highresolution scanning transmission electron microscopy), confirmando a presença de oxocarbonos na superfície dos AuNCs

Todos os experimentos foram realizados em temperatura ambiente de $23^{\circ} \mathrm{C}$. 


\section{2}

\section{Técnicas experimentais}

\subsection{1}

\section{Absorção óptica}

As medidas de absorção óptica UV-visível foram realizadas à temperatura ambiente no espectrofotômetro Hewlett Packard (Agilent), modelo HP - 8452 A. Este espectrofotômetro opera na faixa de 180-820 nm, com sistema de detecção por arranjos de diodos e resolução de $2 \mathrm{~nm}$. O esquema do espectrofotômetro é apresentado na Fig.4.3, mostrando simplificadamente a fonte luminosa e o feixe passando através do monocromador e depois para a amostra. Em seguida passa pela rede de difração, para seleção do comprimento de onda, atingindo o arranjo de diodos do detector. Finalmente esses dados são coletados em um registrador de dados.

Brevemente, o espectrofotômetro realiza a medição obtendo primeiro a intensidade de luz transmitida através da solução padrão, contendo o solvente (ex. tampão, água, solução base), seguida por uma medição da luz transmitida através da amostra dissolvida na mesma solução. A absorbância ou a transmitância são então obtidas através da interface com o computador e do software. Isso é feito ao mesmo tempo para cada comprimento de onda da luz.

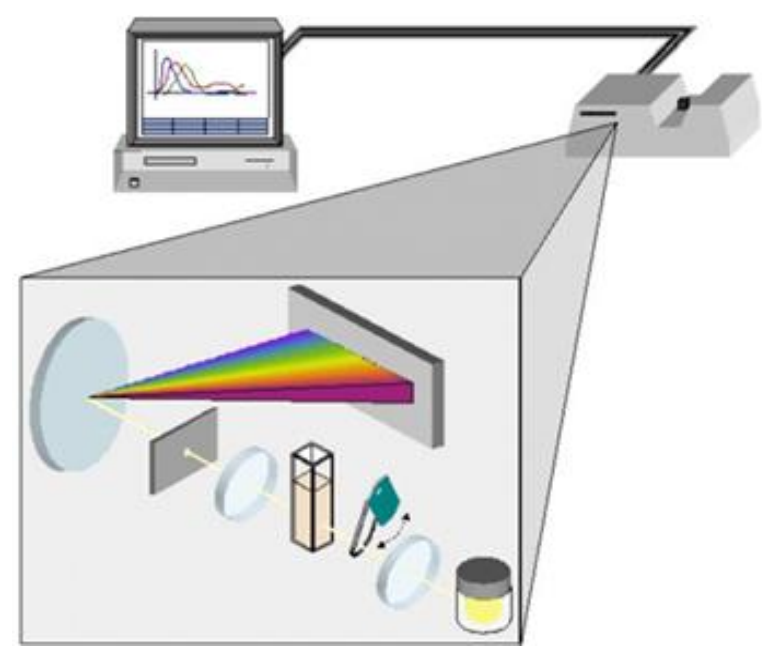

Figura 4.4. Esquema do funcionamento do espectrofotômetro (retirado da Tese de Doutorado de Romero, 2013). 
Os espectros foram medidos utilizando-se um tempo de integração de $1 \mathrm{~s}$. Em algumas experiências utilizamos dois tipos de cubetas de quartzo, de caminho ótico $1,0 \mathrm{~cm}$ e capacidade $3,0 \mathrm{~mL}$, e de caminho óptico $0,4 \mathrm{~cm}$, com capacidade $1,2 \mathrm{~mL}$.

\subsection{2}

\section{Fluorescência}

\section{Sistema de fluorescência estacionária}

As medidas de espectroscopia de fluorescência estacionária foram realizadas utilizando o Sistema de Fluorescência PTI-QM1 (Fig. 4.4), do Laboratório de Espectroscopia de Biomoléculas (Departamento de Física, PUC - Rio).

A Fig. 4.5 mostra o esquema do funcionamento do espectrofluorímetro. Para resumir, o espectrofluorímetro contém uma lâmpada de xenônio como fonte de luz (1), cujo feixe atravessa as fendas de excitação (2) para o módulo de excitação (3), no qual mediante uma rede de difração é selecionado o comprimento de onda (4), que ingressa no compartimento da amostra (5). Parte da luz emitida pela amostra é captada a $90^{\circ}$ e atravessa as fendas de emissão (10), ingressando no módulo de detecção, passando pelo monocromador (rede de difração) de emissão (7) e finalmente chegando à fotomultiplicadora como detector fotossensível (9). Programas de computador automaticamente varrem os comprimentos de onda detectados e apresentam a intensidade de emissão como uma função do comprimento de onda da luz emitida. 


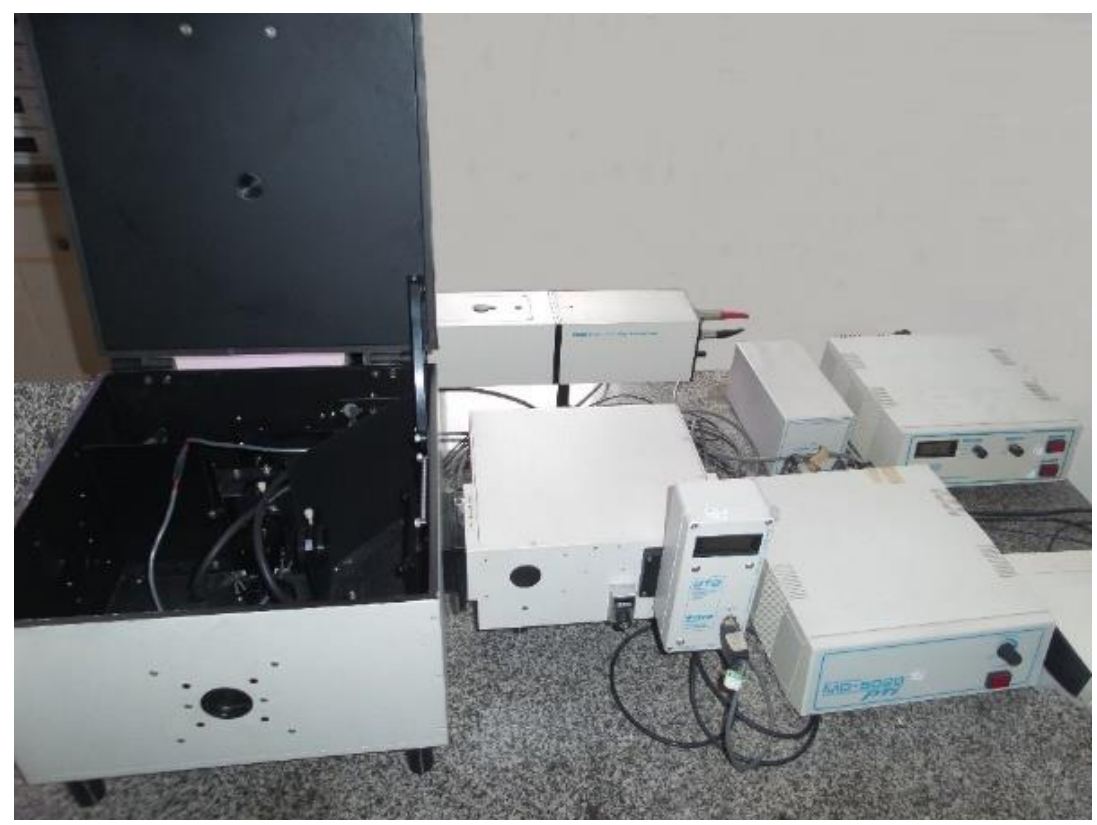

Figura 4.5. Fotografia do Sistema de Fluorescência PTI-QM1 (Photon Technology International).

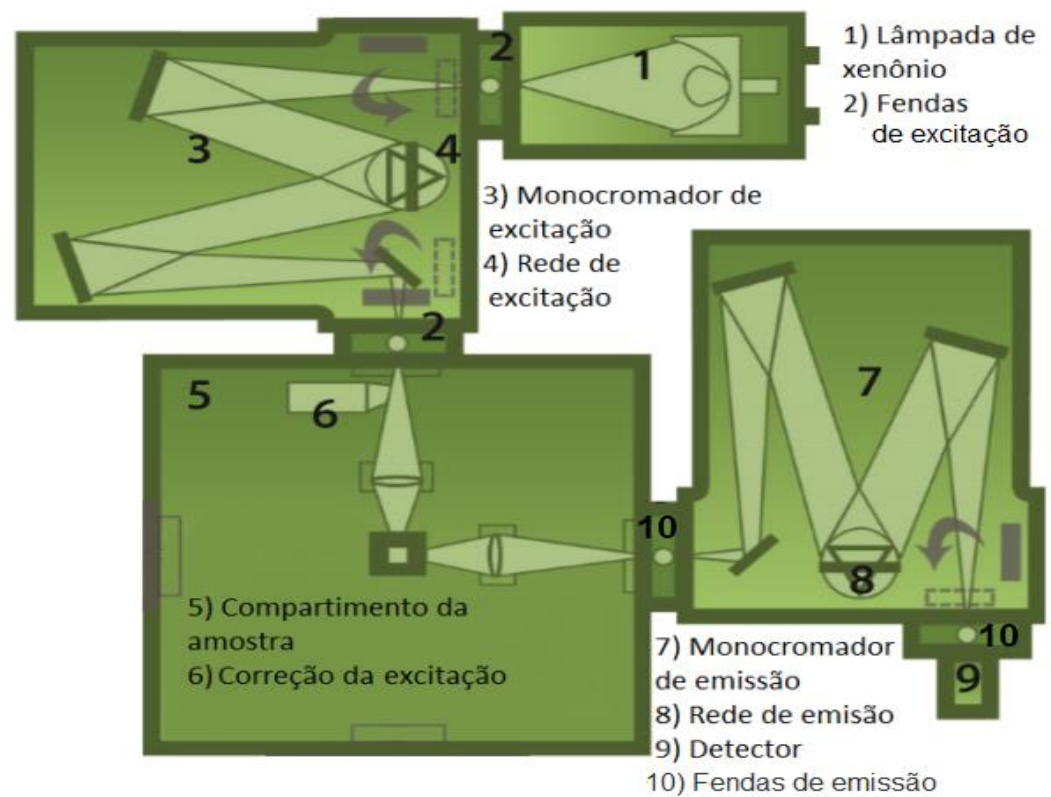

Figura 4.6. Esquema do espectrofluorímetro estacionário utilizado (Adaptado do manual do equipamento PTI QM1).

Os monocromadores em cada compartimento selecionam a frequência dos fótons da radiação incidente e emitida pela amostra. O programa Felix foi utilizado para o controle de varredura do feixe de emissão e excitação.

No caso dos espectros de emissão, dado um comprimento de onda de excitação, se obtém a intensidade de emissão em função do comprimento de onda da luz emitida. No caso dos espectros de excitação, estes representam a intensidade 
de emissão num determinado comprimento de onda, em função do comprimento de onda de excitação.

Todos os experimentos de fluorescência de FQs foram feitos excitando a NFX em $330 \mathrm{~nm}$, levando em conta efeitos de filtro interno. Aberturas das fendas do fluorímetro foram $3 \mathrm{~nm}$ para a excitação e $4 \mathrm{~nm}$ para a emissão. Todas as medidas de absorção/extinção e fluorescência foram feitas em cubeta de $1 \mathrm{ml}$, utilizando o caminho óptico $\ell=0,4 \mathrm{~cm}$ para absorbância e excitação, e $\ell=1,0 \mathrm{~cm}$ para a emissão.

\section{Sistema de fluorescência resolvida no tempo}

A técnica de contagem de fóton único (TSPC) consiste em determinar o tempo decorrido entre um pulso de excitação extremamente curto $\left(\sim 10^{-11}\right.$ segundos, de comprimento de onda bem definido), e o instante em que o primeiro fóton, vindo da relaxação das moléculas excitadas, chega ao detector. Ou seja, há um relógio interno que tem o seu disparo junto com a fonte de luz e cessa na detecção do primeiro fóton da amostra fluorescente. Esses dados são coletados num histograma (sendo o eixo y o número de fótons contados e x o tempo decorrido até a observação dos fótons advindo do fenômeno da fluorescência, Fig. 4.6).

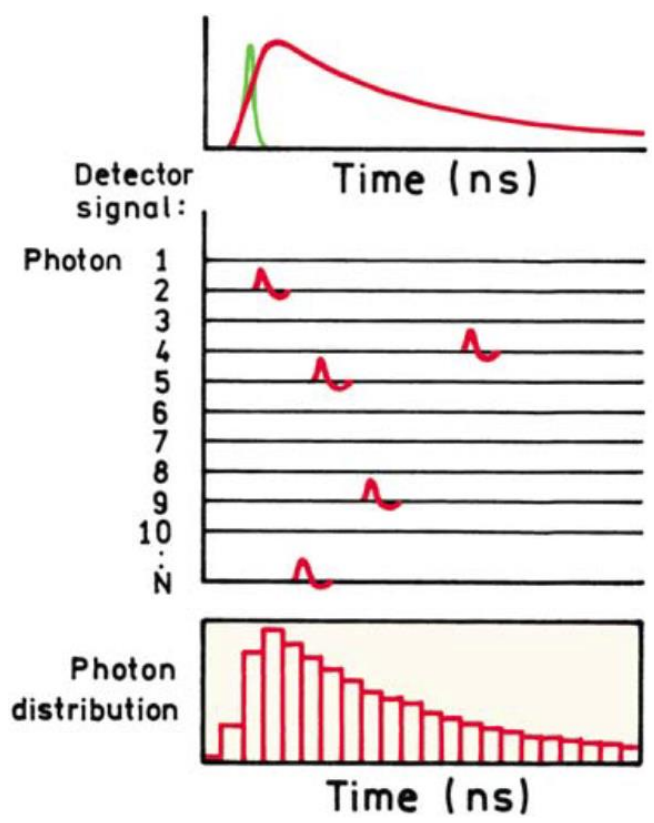

Figura 4.7. Esquema da técnica da contagem de fóton único. (Lakowicz;2006).

O equipamento necessita também monitorar o perfil do pulso de luz, primeiramente porque esses pulsos não são curtos o suficiente para serem 
considerados deltas de Dirac, de maneira que é necessário aplicar um tratamento matemático (deconvolução) para obter corretamente os tempos de vida. Portanto, tempos abaixo da largura a meia altura, que estariam dentro do erro experimental, ainda podem serem estimados.

As experiências de tempo de vida de fluorescência foram realizadas no sistema de fluorescência resolvida no tempo por contagem de fótons (Fig. 4.7) TCSPC 5000 U, IBH-Horiba-JobinYvon (Física, PUC-Rio, projeto PADCT-Rio). Este equipamento se baseia na técnica de contagem de fóton único correlacionada no tempo (TCSPC - Time Correlated Single Photon Counting). O equipamento possui um sistema de bombeamento com uma fonte pulsada que possibilita medidas de tempos de vida 100 ps. Além disso, possui também um conjunto de lasers e LEDs de estado sólido (NanoLEDs) com pulsos de curta duração (<200 ps) e com taxa de repetição de $1 \mathrm{MHz}$, que cobre uma larga faixa do espectro desde $280 \mathrm{~nm}$ até $650 \mathrm{~nm}$. Em nosso caso, para todas as medidas de decaimento de fluorescência foi utilizado um LED de estado sólido (NanoLED), com taxa de repetição de $1 \mathrm{MHz}$ e comprimento de onda de $330 \mathrm{~nm}$, de duração média de $1 \mathrm{~ns}$. O sistema é controlado por computador através de um software comercial adquirido junto com o equipamento (DAS6 - Horiba Jobin Ivon), compatível com Windows.

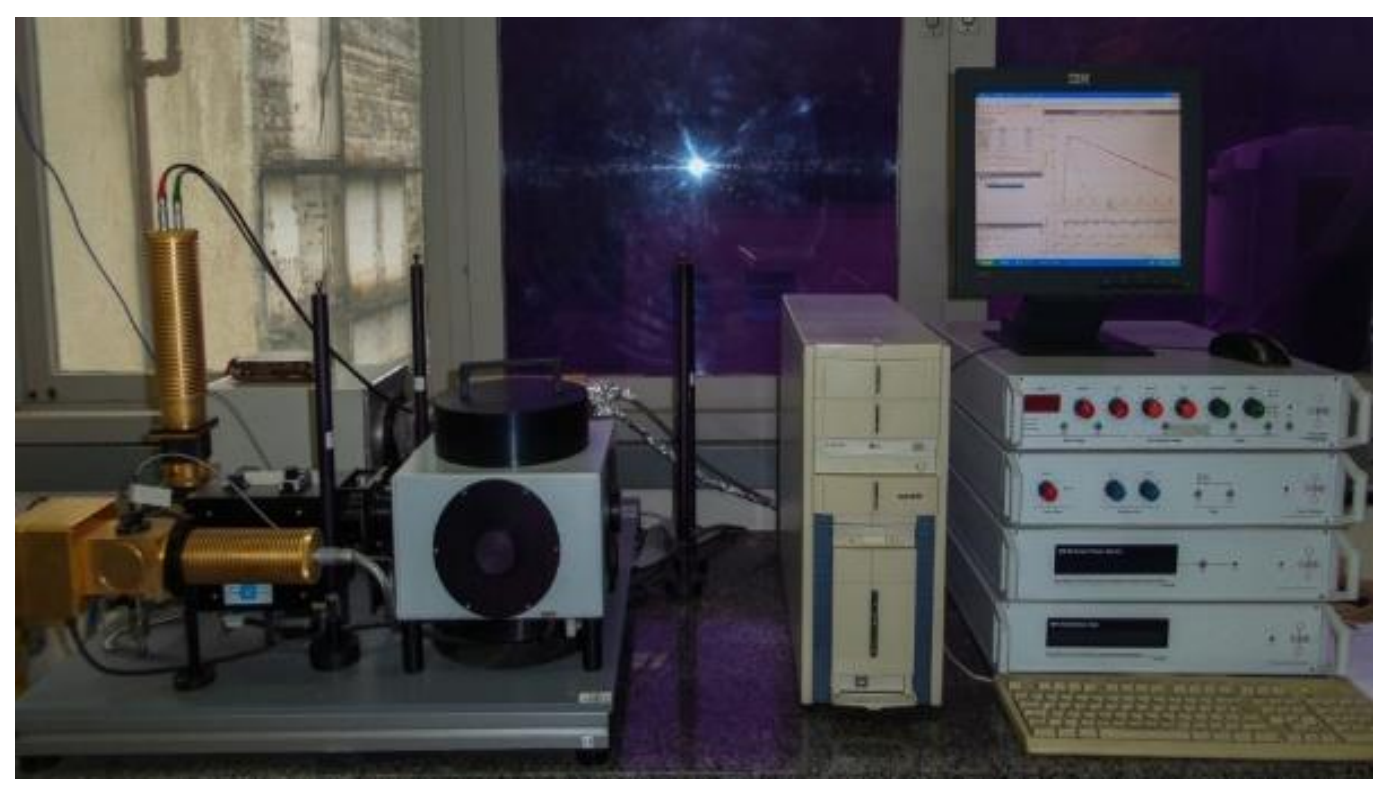

Figura 4.8. Equipamento de fluorescência resolvida no tempo utilizado para medidas de tempos de vida. 
Para a determinação dos tempos de vida e dos demais parâmetros da fluorescência resolvida no tempo foi utilizado o modelo multi-exponencial dado por:

$$
N(t)=A+\sum_{i} \alpha_{i} \exp \frac{-t}{\tau_{i}}
$$

onde $A$ é uma constante associada ao ruído, $\tau_{i}$ são os tempos de vida das espécies presentes na amostra e $\alpha_{i}$ são os fatores pré-exponenciais.

Para ajustar as curvas de decaimento medidas utilizamos dois softwares de análise, o individual e o global. Na análise individual, o programa DAS6 - Horiba Jobin Ivon nos permite realizar ajustes com até cinco exponenciais, ou seja, considerando cinco tempos de vida na equação (Eq. 4.1). A parametrização é realizada através de uma avaliação criteriosa do $\chi^{2}$, o qual deve estar entre 0,8 e 1,2, da distribuição dos resíduos e do comportamento coerente dos parâmetros segundo o nosso modelo multi-exponencial.

\subsection{3}

\section{Ressonância paramagnética eletrônica}

Ressonância paramagnética eletrônica (ou ressonância de spin eletrônico) é uma técnica espectroscópica que permite detectar e, na maioria dos casos, caracterizar moléculas com elétrons desemparelhados, sem alterar ou destruir as moléculas.

Experimentos de ressonância paramagnética eletrônica dos complexos de cobre foram realizados no Laboratório de Ressonância Paramagnética Eletrônica, Centro Brasileiro de Pesquisas Físicas (CBPF, Fig. 4.8)), no espectrômetro Bruker (colaboração com E. Wajnberg e O. Cambraia) e no espectrômetro Miniscope MS 400, Magnettech, do Departamento de Física da UFMG (K. Krambrock). Os espectros foram obtidos a $77 \mathrm{~K}$ utilizando um criostato de imersão em nitrogênio líquido. 


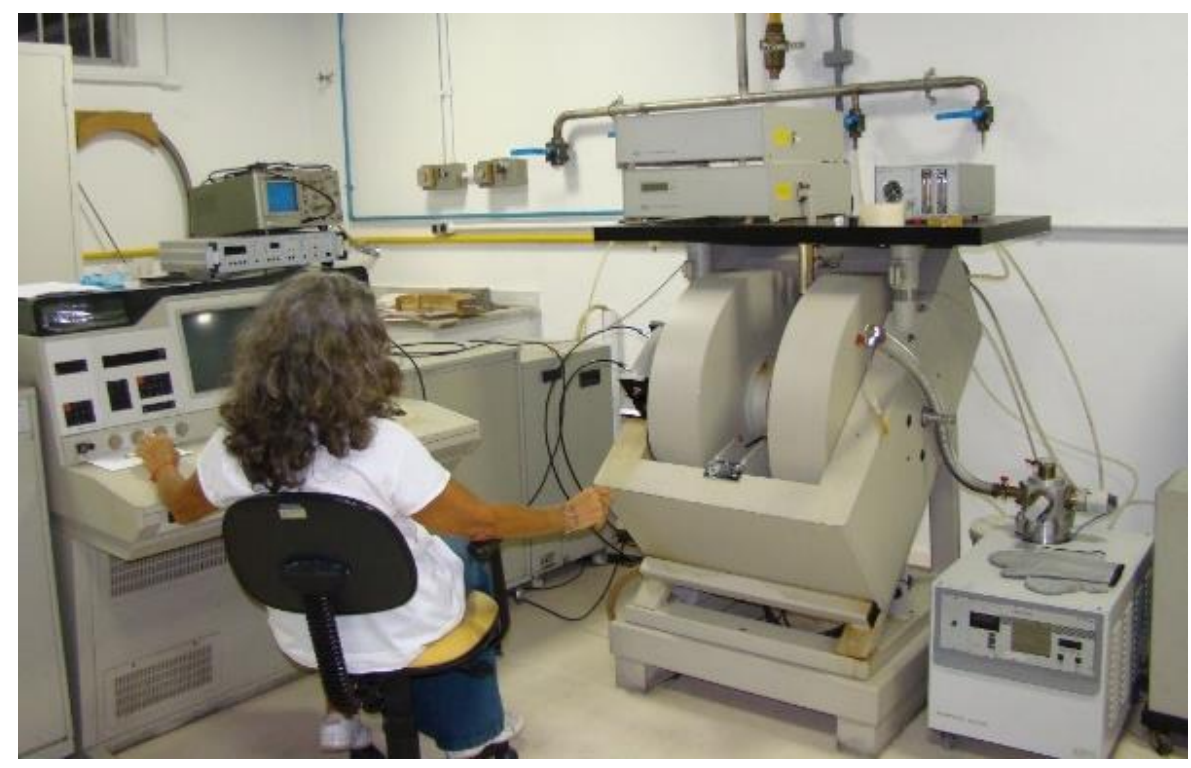

Figura 4.9. Laboratório de Ressonância Paramagnética Eletrônica (RPE), CBPF, mostrando o espectrômetro de RPE (http://mesonpi.cat.cbpf.br/matmult/?pgn=Infraestrutura\%20AssociadaRPE).

\section{3}

\section{Procedimentos}

\subsection{1}

\section{Preparação de amostras}

Preparação de micelas de SDS

Iniciamos o estudo de interação dos complexos com biomembranas investigando a interação dos complexos com micelas, utilizando o surfactante aniônico SDS (Fig. 4.2). Nessa experiência utilizamos tampão fosfato $20 \mathrm{mmol} . \mathrm{L}^{-1}$, pH 7,4. Para o modelo de membranas utilizamos vesículas de fosfolipídios, introduzindo diferentes proporções de ácido esteárico e SDS para variar o potencial de membrana.

Preparação de vesículas unilamelares pequenas de fosfatidilcolina de ovo.

Para a preparação das vesículas unilamelares pequenas (SUVs) foi utilizado clorofórmio $\left(\mathrm{CHCl}_{3}\right)$ e PC, ambos adquiridos da Sigma-Aldrich. Brevemente, para a preparação das SUVs foi utilizado $1,2 \mathrm{ml}$ de $\mathrm{PC} 10 \mathrm{mM}$ solubilizado em $\mathrm{CHCl}_{3}$. Essa solução de PC foi secada com fluxo de gás nitrogênio e colocada no vácuo por 2 horas. Depois desse tempo as películas formadas foram hidratadas com 1,2 mL de PB 10 mM pH 7,4 e submetidas à agitação mecânica em vórtex por 15 segundos 
e logo submetidas três vezes à sonicação, em 12 intervalos de 10 segundos, com descanso de 5 segundos entre intervalos. Depois desse processo, para retirar as impurezas deixadas pelo titânio do sonicador, centrifugamos as amostras e recolhemos $1 \mathrm{~mL}$ do sobrenadante livre de impurezas. Finalmente foi adicionada uma alíquota de NFX para obter na solução uma concentração final de NFX $16 \mu \mathrm{M}$ em SUVs.

Preparação de vesículas unilamelares pequenas de fosfatidilcolina de ovo e ácido esteárico

Para as experiências com ácido esteárico foi preparada uma solução estoque de ácido esteárico $25 \mathrm{mM}$ em etanol, adquiridos da Sigma-Aldrich. Brevemente, foi preparada uma solução estoque 5,5 ml de SUVs PC $10 \mathrm{mM}$ solubilizado em $\mathrm{CHCl}_{3}$. Em seguida distribuímos esta solução em 5 frascos, no qual um deles foi utilizado como o espalhamento para cada conjunto de medidas, e nos outros frascos adicionamos alíquotas de SA o suficiente para obter em cada frasco 0, 2, 4 e $6 \mathrm{mM}$. Essas soluções foram secadas com fluxo de gás nitrogênio e colocadas no vácuo por 2 horas. Depois desse tempo as películas formadas foram hidratadas com $1 \mathrm{~mL}$ de PBS $10 \mathrm{mM}$ e neste caso adicionamos $\operatorname{logo}$ NFX $16 \mu \mathrm{M}$ aos frascos 1, 2, 3 e 4; e submetemos à agitação mecânica por 15 segundos e logo submetidas três vezes à sonicação, em 12 intervalos de 10 segundos, com descanso entre intervalo de 5 segundos. Depois desse processo, para retirar as impurezas deixadas pelo titânio do sonicador, centrifugamos as amostras e recolhemos $0,8 \mathrm{~mL}$ do sobrenadante livre de impurezas, tendo finalmente nas amostras NFX $16 \mu \mathrm{M}$ em SUVs/SA.

Vesículas unilamelares pequenas de fosfatidilcolina e dodecil sulfato de sódio

Para as experiências com SDS se preparou uma solução estoque de SDS $30 \mathrm{mM}$ em etanol. A preparação foi a mesma do que em ácido esteárico, intercambiando apenas o ácido pelo surfactante. Brevemente, foi preparada uma solução estoque 5,5 ml de SUVs PC $10 \mathrm{mM}$ solubilizado em $\mathrm{CHCl}_{3}$. Em seguida distribuímos esta solução em 5 frascos, no qual um deles foi utilizado como o espalhamento para cada conjunto de medidas, e nos outros frascos adicionamos alíquotas de SDS o suficiente para obter em cada frasco 0, 2, 4 e $6 \mathrm{mM}$. Essas soluções foram secadas com fluxo de gás nitrogênio e colocadas no vácuo por 2 horas. Depois desse tempo as películas formadas foram hidratadas com $1 \mathrm{~mL}$ de 
PBS $10 \mathrm{mM}$ e neste caso adicionamos $\operatorname{logo}$ NFX $16 \mu \mathrm{M}$ aos frascos 1, 2, 3 e 4; e submetemos à agitação mecânica por 15 segundos e logo submetidas três vezes à sonicação, em 12 intervalos de 10 segundos, com descanso entre intervalo de 5 segundos. Depois desse processo, para retirar as impurezas deixadas pelo titânio do sonicador, centrifugamos as amostras e recolhemos $0.8 \mathrm{~mL}$ do sobrenadante livre de impurezas, tendo finalmente nas amostras NFX $16 \mu \mathrm{M}$ em SUVs/SDS.

Para o estudo da interação de NFX com DNA, foi utilizado DNA de timo de bezerro, adquirido da Sigma-Aldrich. Nessa experiência utilizamos tampão Tris $5 \mathrm{mM} \mathrm{pH} \mathrm{7,4} \mathrm{com} \mathrm{EDTA} 0.25 \mathrm{mM}$.

Por último, para a interação de AuNCs com as diferentes FQs, utilizaram-se nanopartículas de ouro de camada carbonoide, as quais foram sintetizadas pela técnica de ablação a laser em água ultrapura e ajustando o pH com $\mathrm{NaOH}$ em valores da ordem de 8,0 (cedidas pelo grupo do Prof. Tommaso Del Rosso).

Todos os experimentos foram realizados à temperatura ambiente de $24^{\circ} \mathrm{C}$, com exceção dos experimentos de RPE, que foram realizados a $77 \mathrm{~K}$

\subsection{2}

\section{Interação de norfloxacina com complexos de cobre e com diferentes biomoléculas}

A interação da NFX com diferentes biomoléculas e com íons metálicos é estudada através de espectroscopia de absorção UV-Vis e fluorescência. Por um lado, são observadas as mudanças nos espectros de absorção. Já que a NFX e outras FQs são fluorescentes, utilizamos o fluorímetro para detectar a interação das FQs com diferentes biomoléculas.

Mantendo fixa a concentração da espécie fluorescente (fluorquinolona) e variando a concentração do composto que se associa a esta (complexos de cobre(II), lipossomas, AuNCs) obtém-se variações nos espectros de fluorescência, permitindo traçar as curvas de associação.

Para a análise da supressão de fluorescência, usamos a equação de SternVolmer ou a expressão exata para a variação da fluorescência no modelo de dois estados (fluoróforo livre/ligado) para obter as constantes de associação. Encontramos constantes de associação $K_{b}$ mediante ajuste dos gráficos com as equações características dos modelos. 


\section{Obtenção da constante de estabilidade na formação de complexo 1:1}

Em supressão de fluorescência as constantes de estabilidade $K_{b}$ para $o$ equilíbrio $\mathrm{NFX}+\mathrm{Cu}: \mathrm{L} \leftrightarrow \mathrm{NFX}: \mathrm{Cu}: \mathrm{L}$ foram obtidas utilizando a expressão exata para a formação de um complexo 1:1 [Valeur, 2001], assumindo que a constante de estabilidade para $\mathrm{Cu}$ e Lé muito maior do que para $\mathrm{Cu}$ e NFX:

$$
F_{0}-F=\frac{F_{0}-F_{\infty}}{2}\left\{\left(1+\frac{c_{M}}{c_{L}}+\frac{1}{K_{b} c_{L}}\right)-\left[\left(1+\frac{c_{M}}{c_{L}}+\frac{1}{K_{b} c_{L}}\right)^{2}-4 \frac{c_{M}}{c_{L}}\right]^{1 / 2}\right\}
$$

onde $K_{b}$ é a constante de ligação do complexo binário $\mathrm{Cu}: \mathrm{L}$ com NFX, $c_{L}$ e $c_{M}$ são as concentrações do ligante NFX e do complexo metálico $\mathrm{Cu}: \mathrm{L}$, respectivamente; $F_{0}, F$ e $F_{\infty}$ são as intensidades de fluorescência da NFX na ausência de Cu:L, a uma concentração dada de $\mathrm{Cu}: \mathrm{L}$, e para $c_{L<<} c_{M}$, respectivamente. Quando há supressão completa, $F_{\infty}$ é nula. É importante notar que a equação 4.2 se resume na Equação de Stern-Volmer, no caso de a constante de associação $K_{b}$ ser pequena, de modo que a concentração total do supressor $\left(c_{M}\right)$ seja da ordem da concentração de supressor livre $\left(c_{M} \approx[\mathrm{Cu}: \mathrm{L}]\right)$.

\section{Correções em medidas de fluorescência}

\section{Correção do efeito de filtro interno}

Muitas vezes a intensidade da luz de excitação incidente pode ser diminuída significativamente ao chegar no meio da cubeta contendo a amostra, assim como ser atenuada a fluorescência observada, devido a que a própria amostra pode absorver a luz incidente e/ou a luz emitida. Isto vai depender da densidade ótica da amostra nos comprimentos de onda de emissão e excitação. Como isto pode influenciar a intensidade de fluorescência e mudar os dados obtidos, se faz a seguinte correção devido a estes efeitos de filtro interno:

$$
F_{c}=F \times 10^{A_{e x c(l)}+A_{e m(l)}}=F \times 10^{\left(\ell_{e x c} \cdot A_{e x c}+\ell_{e m} \cdot A_{e m}\right) / 2}
$$

onde $F_{c}$ é a intensidade da fluorescência real (corrigida), $F$ é a fluorescência obtida (dados). $A_{\operatorname{exc}(l)}$ é a absorbância no comprimento de onda de excitação e $A_{\operatorname{em}(l)}$ é a absorbância em cada comprimento de onda de emissão, associadas ao caminho ótico até o ponto de excitação e emissão, respectivamente. Na geometria de fluorescência, utilizando-se cubetas quadradas, pode-se aproximar o centro da 
cubeta como o ponto em que ocorre a excitação e a emissão. Então o caminho ótico será metade do caminho utilizado para medir a absorbância (l/2). Sendo assim utiliza-se $A_{e x c(l)}=A_{e x c} \cdot \ell_{\mathrm{exc}} / 2$, e $A_{e m(l)}=A_{e m} \cdot \ell_{\mathrm{em}} / 2$, para corrigir o efeito de filtro interno.

\section{Correção da diluição}

Em medidas de fluorescência assim como de absorção, também é importante corrigir os efeitos de diluição quando os volumes das amostras variam mais do que $1 \%$ nas titulações. Para esta correção, a fórmula é:

$$
F_{c}=F \times\left(V_{0}+V_{\text {aliq }}\right) / V_{0}
$$

Aqui, $F_{c}$ é a intensidade da fluorescência corrigida, $F$ é a fluorescência obtida, $V_{0}$ é o volume da amostra inicial da amostra e $V_{a l i q}$ o volume das alíquotas adicionadas. Com isto, considerando estas duas correções, obtém-se a seguinte expressão para a intensidade de fluorescência corrigida:

$$
F_{c}=F \times \frac{\left(V_{0}+V_{\text {aliq }}\right)}{V_{0}} \times 10^{\left(\ell_{e x c} \cdot A_{e x c}+\ell_{e m} \cdot A_{e m}\right) / 2}
$$




\section{Resultados e Discussões}

\section{1 \\ Interação dos complexos [ $\mathrm{CuCl}_{2}$ (Bipy)] e $\left[\mathrm{CuCl}_{2}\right.$ (Phen)] com norfloxacina em micelas de SDS}

Complexos metálicos sintetizados podem se dissociar em soluções aquosas, por isto é importante conhecer as constantes de estabilidade $K_{b}$ do metal:ligante. Para o caso dos complexos binários Cu:Bipy e Cu:Phen, estas constantes são da ordem de $10^{8}$ e $10^{9} \mathrm{M}^{-1}$ [Turkel e Sahin, 2009]. Como estas são bem maiores do que a constante de associação de cobre(II) com a NFX, a formação dos complexos ternários de $\mathrm{Cu}$ :Bipy e $\mathrm{Cu}$ :Phen com NFX pode ser tratada como a associação do complexo binário com o ligante NFX. Nesse caso, a constante de associação é dada por $K_{b}=$ [Cu:L:NFX] / ([Cu:L][NFX], sendo "L” Bipy ou Phen.

Devido a que o íon de cobre(II) é bom supressor de fluorescência, as constantes $K_{b}$ podem ser obtidas pela supressão da fluorescência. Assim, em trabalho anterior, Muniz, Incio et al., 2017 encontramos as constantes de associação $K_{b}$ da NFX aos complexos de cobre-bipiridina (1) e cobre-fenantrolina (2) em tampão fosfato $20 \mathrm{mM}$ :

$$
\begin{aligned}
& K_{b}^{(1)}=(1,48 \pm 0,02) \times 10^{5} \mathrm{M}^{-1}, \\
& K_{b}^{(2)}=(1,80 \pm 0,02) \times 10^{5} \mathrm{M}^{-1} .
\end{aligned}
$$

Muniz et al., 2014, mostraram que a força iônica e a presença de estruturas eletricamente carregadas nas soluções influenciam grandemente na associação da NFX ao complexo binário.

A interação da norfloxacina com micelas do detergente aniônico SDS foi estudada anteriormente usando a fluorescência intrínseca da NFX [Muniz et al., 2014]. Foi encontrado que as formas catiônica e zwiteriônica da NFX (pH 4,0 e $\mathrm{pH} 7,4$, respectivamente), associadas a micelas de SDS, têm constantes de associação 5,48 $\times 10^{3} \mathrm{M}^{-1} \mathrm{e} 1,7 \times 10^{3} \mathrm{M}^{-1}$, respectivamente. $\mathrm{O}$ rendimento quântico 
de fluorescência de ambas espécies aumenta quando NFX se liga às micelas de SDS, deslocando o pico, de $440 \mathrm{~nm}$ em $\mathrm{pH} 4,0$ ou de $407 \mathrm{~nm}$ em pH 7,4, para $432 \mathrm{~nm}$.

Nessa parte do trabalho, realizamos o estudo da interação dos complexos de $\mathrm{Cu}$ :Bipy e Cu-Phen com NFX associada a micelas de SDS. Nosso objetivo foi analisar como as micelas aniônicas influenciam a formação e a estrutura dos complexos ternários.

Muniz et al., 2014, também mostraram que a NFX encontra-se totalmente ligada a micelas de SDS, em soluções de SDS 20 mM, pH 7,4 (concentração micelar crítica $\left.\mathrm{CMC}_{\mathrm{SDS}}=2,65 \times 10^{-3} \mathrm{M}\right)$. Preparamos então uma solução de SDS $20 \mathrm{mM}$ e NFX $8 \mu \mathrm{M}$ (NFX diluída a partir de estoque 1,6 mM em água levemente acidificada para solubilizar NFX), a fim de ter certeza que a NFX se encontra ligada às micelas.

Titulamos a solução contendo NFX em SDS, ambas em concentrações fixas, com os complexos $\mathrm{Cu}$ :Bipy e $\mathrm{Cu}$ :Phen, para observarmos as mudanças nos espectros de absorção, fluorescência estacionária e resolvida no tempo. Como controle, também titulamos NFX em SDS com cloreto de cobre (II), para comparar com os resultados da titulação com os complexos. A Fig. 5.1 mostra o esquema da interação dos complexos de Cu-Phen com NFX associada a micelas de SDS.

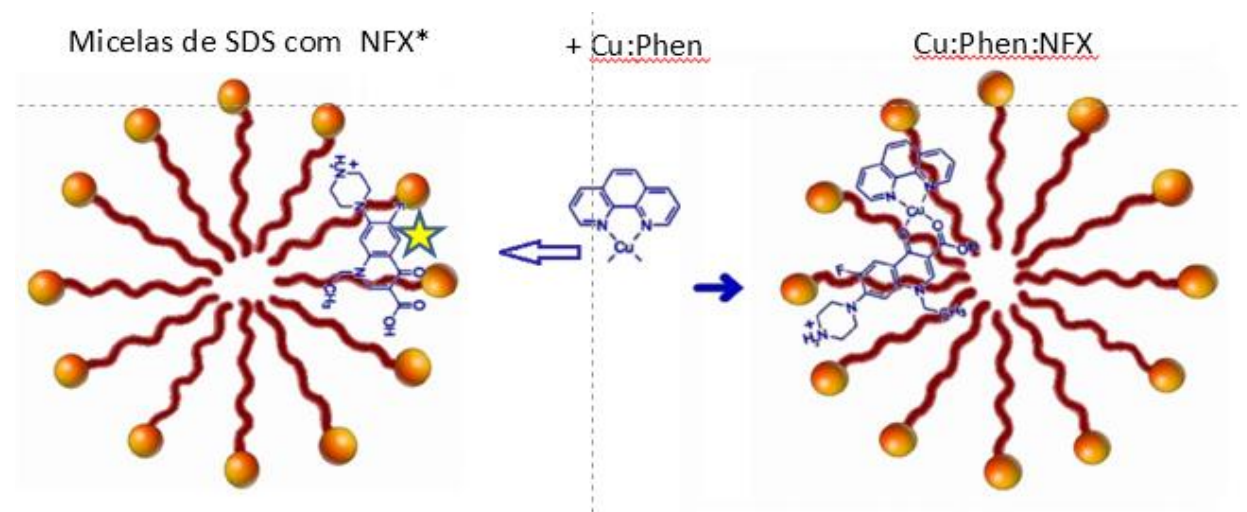

Figura 5.1. Esquema ilustrando a interação de Cu:Phen com NFX dentro das micelas de SDS. (Adaptado de Muniz, Incio et al., 2017). 


\subsection{1}

\section{Absorção e fluorescência da NFX em micelas de SDS titulada com os complexos Cu:Bipy e Cu:Phen}

Apresentaremos, a seguir, resultados de absorção UV-Vis assim como os de fluorescência da NFX em micelas de SDS, em presença de concentrações crescentes dos complexos de cobre.

Nas Fig. $5.2\left(a_{1}\right),\left(b_{1}\right)$ e $\left(c_{1}\right)$ são mostrados os espectros de absorção de NFX titulada com os complexos $\mathrm{Cu}$ :Bipy, $\mathrm{Cu}$ :Phen e $\mathrm{CuCl}_{2}$. Como os complexos absorvem na região UV do espectro, nota-se uma crescente contribuição para a absorção nessa região. Para verificar se os espectros são apenas superposição de compostos ou se houve modificação dos espectros individuais devido à complexação, foram feitas análises mediante subtração do espectro inicial de NFX. Podemos ver na subtração de espectros, Figs. $5.2\left(a_{2}\right),\left(b_{2}\right)$ e ( $\left.c_{2}\right)$, uma modificação dos espectros devido à formação dos complexos. Na Fig. $5.2\left(\mathrm{c}_{2}\right)$, há uma leve modificação na absorbância da NFX em micelas de SDS ao adicionar $\mathrm{CuCl}_{2}$. Já a titulação com $\mathrm{Cu}$ :Bipy e $\mathrm{Cu}$ :Phen modifica bastante os espectros de absorção (Fig. $5.2\left(\mathrm{a}_{2}\right)$, $\left.\left(\mathrm{b}_{2}\right)\right)$, em relação aos espectros dos dois complexos Cu:Bipy e $\mathrm{Cu}:$ Phen.

Os espectros de fluorescência da NFX em micelas de SDS titulada com os complexos $\mathrm{Cu}$ :Bipy, $\mathrm{Cu}$ :Phen e com $\mathrm{CuCl}_{2}$ foram obtidos e os resultados são apresentados na Fig. 5.3. Observa-se inicialmente uma diminuição da intensidade de fluorescência, sem deslocamento do pico, característica de supressão de fluorescência. Em concentrações maiores de complexo, em que a supressão é mais acentuada, há um deslocamento do pico para o azul, para $407 \mathrm{~nm}$ em ambos complexos (Cu:Bipy e $\mathrm{Cu}$ :Phen). Essa fase não ocorre na titulação com $\mathrm{CuCl}_{2}$, sendo possível perceber uma supressão em $431 \mathrm{~nm}$ sem deslocamento do pico.

A NFX em solução aquosa, pH 7,4, apresenta pico de fluorescência em $407 \mathrm{~nm}$, enquanto que ligada a micelas de SDS o pico desloca-se para $432 \mathrm{~nm}$ [Muniz, 2013]. Logo, o pico inicial em $431 \mathrm{~nm}$ dos espectros da Fig. 5.3 (a), (b) e (c) indicam que praticamente todas as moléculas de NFX estão realmente associadas às micelas de SDS num momento inicial. 

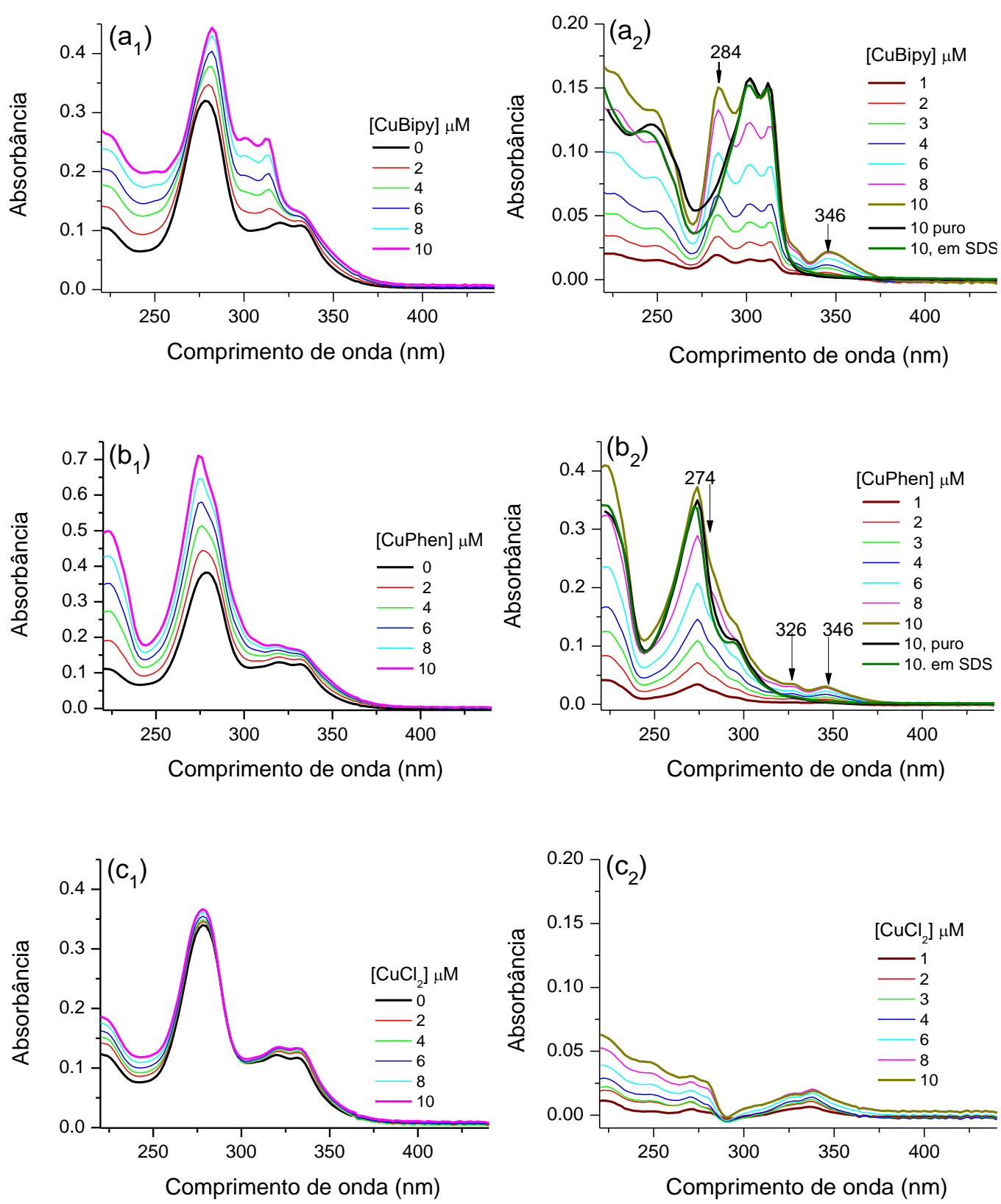

Figura 5.2. Espectros de absorção da NFX $8 \mu \mathrm{M}$ em SDS $20 \mathrm{mM}$, titulada com cobre e seus complexos ( $a_{1}$ ) Cu:Bipy, ( $\left.b_{1}\right) \mathrm{Cu}$ :Phen e ( $\left.c_{1}\right)$ o sal $\mathrm{CuCl}_{2}$. Espectros (a2), ( $\left.\mathrm{b}_{2}\right)$ e ( $\left.\mathrm{c}_{2}\right)$ são resultados de subtrair o espectro inicial de cada série dos espectros ( $\left.a_{1}\right),\left(b_{1}\right),\left(c_{1}\right)$ (NFX em SDS). 
(a)

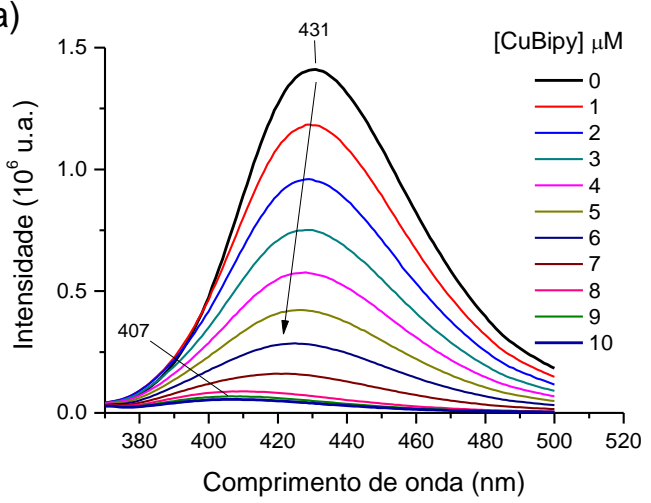

(b)

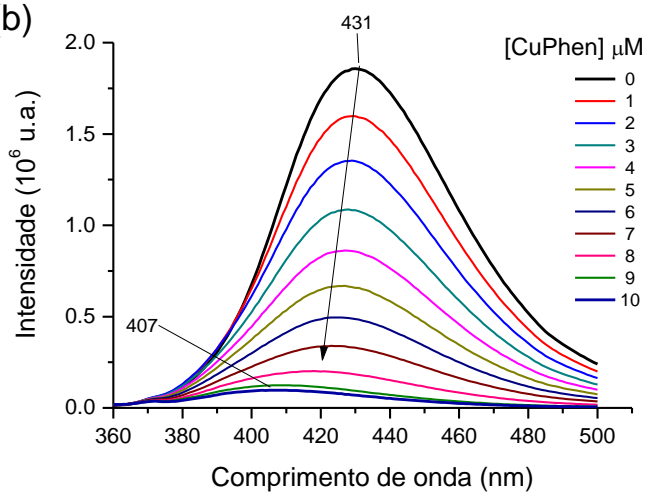

(c)

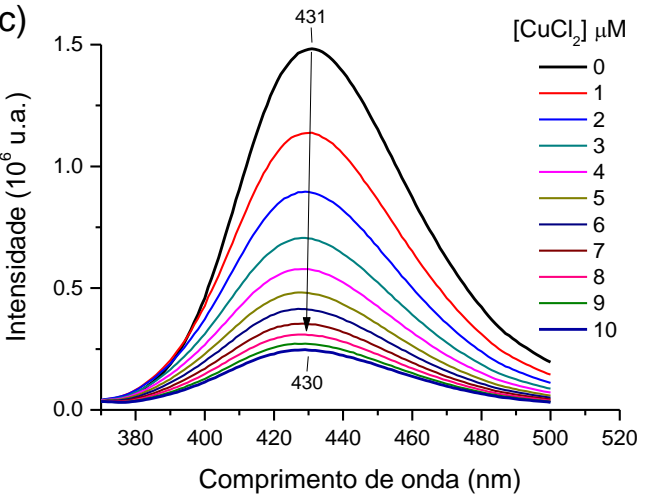

Figura 5.3. Espectros de fluorescência da NFX $8 \mu \mathrm{M}$ em SDS $20 \mathrm{mM}$, e o efeito da titulação com (a) Cu:Bipy, (b) Cu:Phen e (c) $\mathrm{CuCl}_{2}$. Medidas com excitação em $330 \mathrm{~nm}$.

Para a interpretação dos resultados da Fig. 5.3 deve-se ter em conta que os íons de cobre (II) são paramagnéticos e, portanto, supressores de fluorescência. Podemos deduzir que, a fluorescência máxima em $432 \mathrm{~nm}$ indicaria que praticamente todas as moléculas de NFX estão ligadas às micelas o qual está de acordo para uma concentração alta de SDS $20 \mathrm{mM}$, e os complexos de cobre $\mathrm{Cu}$ :Bipy e $\mathrm{Cu}$ :Phen, ao se associarem às micelas, suprimem completamente a fluorescência das moléculas de NFX. Ao utilizar como controle $\mathrm{CuCl}_{2}$, vemos que não há deslocamento do pico de fluorescência, o deslocamento aparece apenas para os complexos. Conclui-se que as micelas aniônicas de SDS favorecem a formação dos complexos mistos. O espectro remanescente com máximo em torno de $407 \mathrm{~nm}$ deve-se, provavelmente, à pequena proporção de NFX não associada às micelas, cuja fluorescência não estaria suprimida pela ligação aos complexos.

A Fig. 5.4 apresenta gráficos de variação da fluorescência da NFX em micelas de SDS em 431 nm, como função da concentração dos complexos. Esses resultados serão analisados de acordo com diferentes modelos de associação. 
(a)

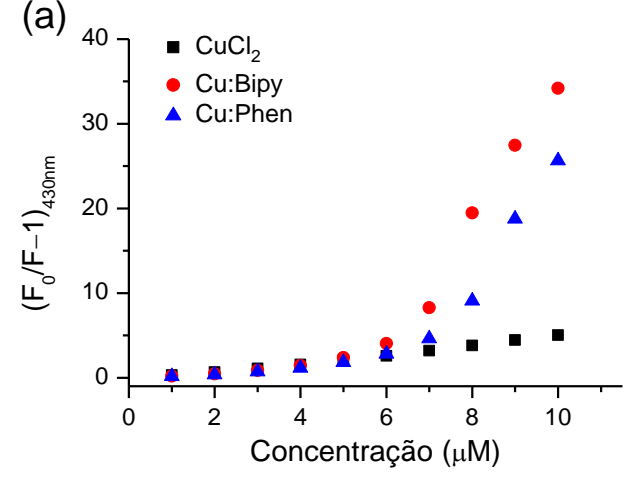

(b)

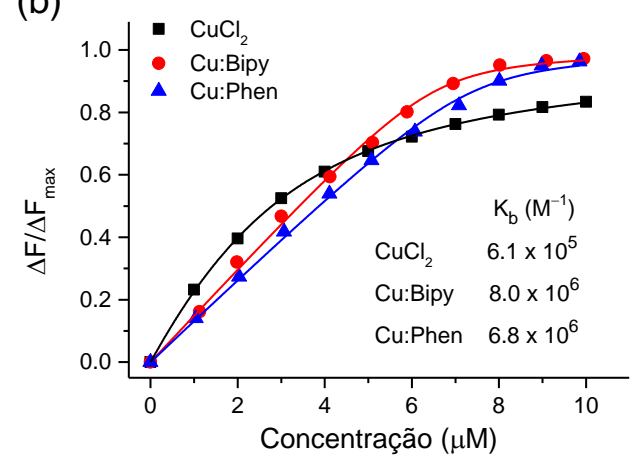

Figura 5.4. (a) Gráficos de Stern-Volmer para a fluorescência da NFX em micelas de SDS, em $430 \mathrm{~nm}$, como função da concentração dos complexos de cobre e de $\mathrm{CuCl}_{2}$. (b) Variação normalizada da fluorescência da NFX como função da concentração dos complexos de Cu:Phen, Cu:Bipy e $\mathrm{Cu}: \mathrm{Cl}_{2}$. Linhas sólidas: ajustes por mínimos quadrados usando Eq. 4.2.

Mediante o gráfico de Stern-Volmer (Fig. 5.4 (a)) podemos ver que o gráfico não é linear, portanto não podemos obter constantes de inclinação relacionadas às constantes de associação. Foi necessário utilizar o modelo exato de dois estados para formação do complexo misto (NFX livre, NFX associada a Cu:Bipy ou $\mathrm{Cu}$ :Phen). A partir desses dados experimentais (Fig. 5.4 (b)), foi possível ajustar e obter as constantes de estabilidade para a formação do complexo ternário $\mathrm{Cu}: \mathrm{L}: \mathrm{NFX}$ no interior das micelas:

$$
\begin{aligned}
& K_{b}{ }^{(\mathrm{Cu})} \mathrm{SDS}=(6,1 \pm 0,1) \times 10^{5} \mathrm{M}^{-1}, \text { para Cu}(\mathrm{II}): \mathrm{NFX}, \\
& K_{b}{ }^{(1)} \mathrm{SDS}=(8,0 \pm 1,8) \times 10^{6} \mathrm{M}^{-1}, \text { para Cu:Bipy:NFX, e } \\
& K_{b}{ }^{(2)} \mathrm{SDS}=(6,8 \pm 1,3) \times 10^{6} \mathrm{M}^{-1}, \text { para Cu:Phen:NFX. }
\end{aligned}
$$

Essas constantes são muito maiores do que as obtidas em tampão. Por exemplo, para Cu:Phen:NFX em SDS, o valor da constante, $\mathrm{K}_{\mathbf{b}}{ }^{(2)} \mathrm{SDS}=6,8 \times 10^{6}$ $\mathrm{M}^{-1}$, é 60 vezes maior do que em PB, $K_{b} \sim 1,0 \times 10^{5} \mathrm{M}^{-1}$ [Muniz, Incio et al., 2017, Fig. 3].

Podemos concluir então, da supressão de fluorescência e das constantes de estabilidade obtidas, que as micelas de SDS favorecem a interação da NFX com os complexos $\mathrm{Cu}$ :Bipy e $\mathrm{Cu}$ :Phen, em pH 7,4, apresentando uma estabilidade maior do que o complexo ternário em tampão. 


\section{1 .2}

\section{Decaimento da fluorescência}

Durante a titulação com os ligantes foi também analisado o decaimento da fluorescência. A Fig. 5.5 apresenta os gráficos do número de fótons emitidos em função do tempo após o pulso de excitação, para amostras com diferentes concentrações de $\mathrm{Cu}$ :Bipy. Uma rápida análise das curvas mostra que não há variação no tempo de vida de fluorescência quando aumentamos a concentração do complexo. Os gráficos com $\mathrm{Cu}: \mathrm{Phen}$ e $\mathrm{Cu}: \mathrm{Cl}_{2}$ tiveram a mesma forma.

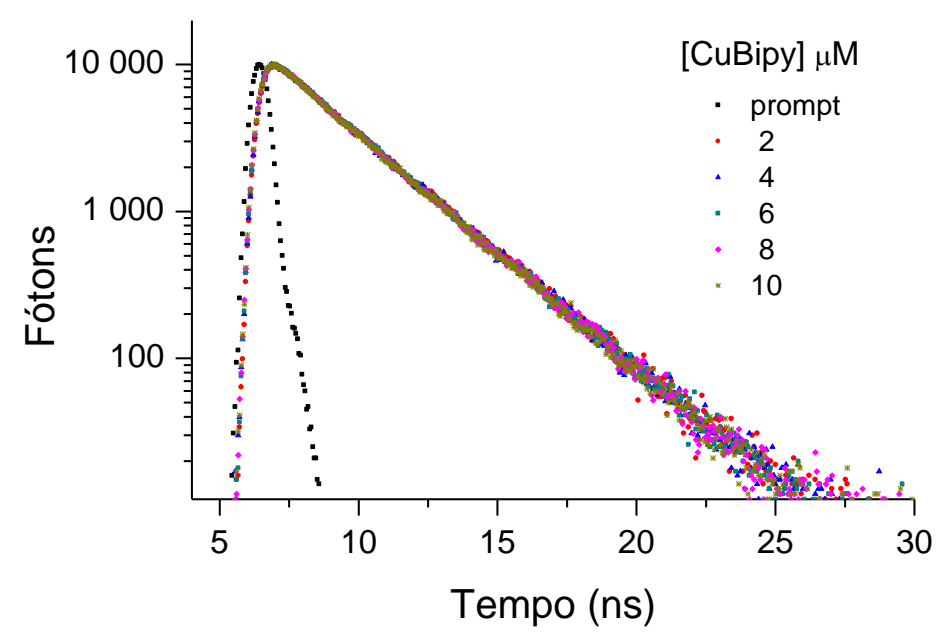

Figura 5.5. Decaimento da fluorescência da NFX em micelas de SDS e concentrações crescentes de Cu:Bipy. Excitação em $330 \mathrm{~nm}$.

Concluímos que o mecanismo de supressão da fluorescência da NFX é estático, por formação de complexo não fluorescente.

\subsection{3}

\section{Ressonância paramagnética eletrônica}

Martins et al., 2016, mostraram, mediante a espectroscopia de RPE, que os complexos mistos ternários Cu:Bipy:NFX e Cu:Phen:NFX em soluções aquosas e concentrações da ordem de $\mathrm{mM}$ formam quase exclusivamente complexos binucleares, com a estrutura de um dímero $(\mathrm{Cu}: \mathrm{L}: \mathrm{NFX})_{2}$.

De acordo com a supressão de fluorescência da NFX pelos complexos, deduzse que $\mathrm{Cu}$ :Phen e $\mathrm{Cu}$ :Bipy se associam às micelas de SDS, localizando-se muito próximos às moléculas de NFX. No entanto, estes resultados não são capazes de 
comprovar que os complexos mistos $\mathrm{Cu}$ :Phen:NFX e $\mathrm{Cu}$ :Bipy:NFX tenham se formado, associados às micelas de SDS.

A técnica que pode responder se realmente o complexo misto se formou é RPE, já que é capaz de sondar o campo cristalino no entorno do íon $\mathrm{Cu}(\mathrm{II})$.

Os espectros de RPE de Cu:Phen e Cu:Bipy foram obtidos em presença de NFX associada às micelas de SDS (Fig. 5.6, espectros (2) e (4)), e em micelas de SDS (25 mM) na ausência de NFX (Fig. 5.6, espectros (1) e (3)), como controle. Os parâmetros de RPE obtidos dos espectros são mostrados na Tabela 1.

Tabela 1. Parâmetros de dos complexos de Cu (II).

\begin{tabular}{ccccc}
\hline $\begin{array}{c}\mathrm{SDS} \\
(77 \mathrm{~K})\end{array}$ & $\mathrm{g}_{\perp}$ & $\mathrm{g}_{\|}$ & $\mathrm{g}_{\text {binuc }}$ & $\begin{array}{c}\mathrm{D} \\
\text { (gauss) }\end{array}$ \\
\hline$\left[\mathrm{Cu}: \mathrm{Cl}_{2}\right.$ (phen) & 2,08 & 2,22 & & \\
\hline $\begin{array}{c}\text { (3) Cu:Bipy } \\
\text { (1) Cu:Phen }\end{array}$ & & & 2,051 & 530 \\
\hline \hline $\begin{array}{c}\mathrm{SDS} \\
(77 \mathrm{~K})\end{array}$ & $\mathrm{g}_{\perp}$ & $\mathrm{g}_{\|}$ & $\begin{array}{c}\mathrm{A}_{\|} \\
\text {(gauss) }\end{array}$ & \\
\hline & & & & 530 \\
\hline (4) $\mathrm{Cu}:$ Bipy: NFX & 2,031 & 2,222 & 182 & \\
\hline (2) $\mathrm{Cu}:$ Phen: NFX & 2,031 & 2,226 & 180 & \\
\hline
\end{tabular}

Os espectros mostram que o campo cristalino nas vizinhanças dos íons de cobre muda completamente quando as micelas contêm NFX, indicando que realmente o complexo misto se forma nas micelas.

O espectro dos complexos binários Cu:L (Fig. 5.6, espectros (1) e (3)) é uma superposição de espécies binucleares e mononucleares, mas os parâmetros das espécies mononucleares não estão bem definidos. No entanto, os complexos ternários formados dentro das micelas (espectros (2) e (4)), possuem parâmetros muito bem definidos, de espécie axialmente simétrica, característicos dos complexos mononucleares. 


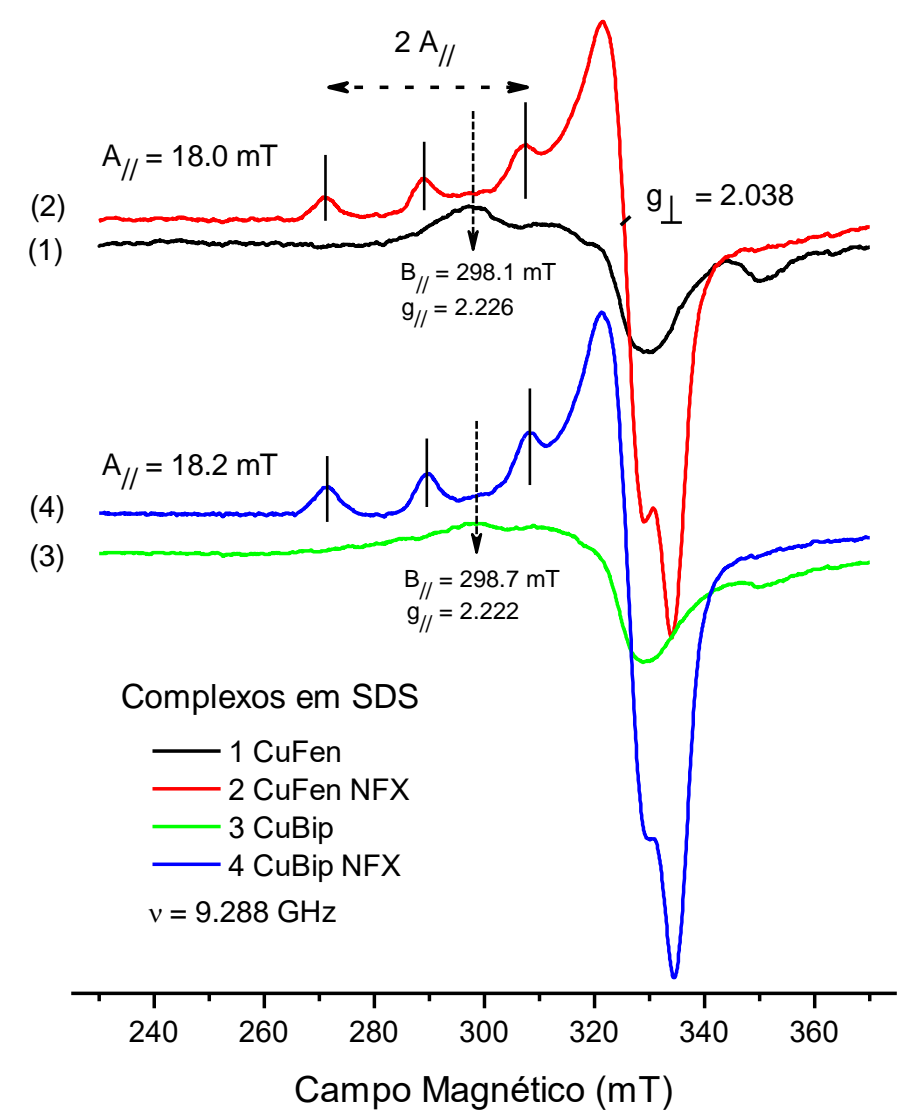

Figura 5.6. Espectros de RPE dos complexos Cu:Phen $(1,2)$ e Cu:Bipy $(3,4)$ em micelas de SDS na ausência de NFX (1,3), e em micelas de SDS carregadas com NFX (2, 4). (77ํㅡ, PB 10 mM, pH 7,4) $[\mathrm{NFX}]=[\mathrm{Cu}:$ Bipy $]=[\mathrm{Cu}:$ Phen $]=\left(1 \times 10^{-3} \mathrm{M}\right) ;[\mathrm{SDS}]=25 \times 10^{-3} \mathrm{M}$.

Os diagramas de Peisach-Blumberg [Peisach e Blumberg, 1974] são gráficos dos parâmetros de RPE $\mathrm{A}_{\|}$versus $\mathrm{g}_{\|}$, que refletem a natureza dos átomos ligados ao $\mathrm{Cu}(\mathrm{II})$. De acordo com esses diagramas, valores de $\mathrm{g}_{\|} \approx 2,22$ e $\mathrm{A}_{\|} \approx 180$ gauss são esperados para 2 átomos de nitrogênio e 2 átomos de oxigênio numa geometria quadrado planar. Isso está de acordo com a estrutura prevista para os complexos ternários Cu:Bipy:NFX e Cu:Phen:NFX, já que NFX se liga aos íons de cobre através de dois átomos de oxigênio (da piridona e do carboxilato), e a Bipy e a Phen se ligam ao cobre através dos dois átomos de nitrogênio da piridina (Fig. 4.1) [Muniz, Incio et al., 2017].

Portanto, nesta seção conclui-se que o ambiente micelar com a superfície carregada negativamente facilita a formação do complexo misto. Os espectros de RPE mostraram que esses complexos são do tipo mononuclear, de parâmetros axialmente simétricos correspondentes à presença de 2 átomos de nitrogênio e 2 de 
oxigênio ligados de forma coordenada ao íon de cobre. Os complexos de cobre do tipo binuclear apresentam características muito diferentes [Martins et al., 2016].

Os resultados desse trabalho mostram a importância da influência micelar aniônica na formação do complexo ternário com NFX, como importante ligante zwiteriônico farmacológico. Essa influência modifica a estrutura do complexo e incrementa a estabilidade. A técnica de RPE foi uma ferramenta importante nessa experiência, mostrando detalhes das variações estruturais de diferentes espécies paramagnéticas ligadas a biomembranas.

\section{2}

\section{Influência de vesículas unilamelares pequenas de fosfatidilcolina de ovo na interação da norfloxacina com o complexo Cu:Phen}

A fim de continuar o estudo das interações de NFX com biomembranas, nesta seção estudaremos as interações de NFX com modelos mais realísticos, como são as vesículas de lipídios. Lembrando que moléculas de ácido esteárico (SA) e de SDS são anfifílicas e apresentam-se negativamente carregadas em solução aquosa em pH neutro, preparamos SUVs de PC com diferentes concentrações de cargas elétricas superficiais negativas variando a proporção de SA ou SDS em relação aos lipídios.

Todas as experiências foram realizadas a temperatura ambiente de $23^{\circ} \mathrm{C}$, utilizando água Milli-Q nas preparações. A concentração de PC nas SUVs preparadas foi $10 \mathrm{mM}$ (seção 4.3.1). Quando usado o tampão fosfato e fosfato salino, o pH se manteve em 7,4. Em todas as medidas de fluorescência, o comprimento de onda de excitação utilizado foi de $330 \mathrm{~nm}$. Aberturas das fendas do fluorímetro foram $3 \mathrm{~nm}$ para a excitação e $4 \mathrm{~nm}$ para a emissão, salvo especificado diferentemente.

Nestas experiências tentaremos obter as constantes de estabilidade para os complexos $\mathrm{Cu}:$ Phen:NFX formados na presença das vesículas. 


\section{2 .1}

\section{Vesículas unilamelares pequenas de fosfatidilcolina de ovo}

Nesta seção estudaremos a influência de SUVs zwitteriônicas de PC preparadas em tampão fosfato $10 \mathrm{mM}, \mathrm{pH}$ 7,4 (PB) e em tampão fosfato salino 10 mM, pH 7,4, NaCl 0,15 M (PBS) na interação de NFX com o complexo $\mathrm{Cu}:$ Phen. Ao final se obtém uma solução de NFX $16 \mu \mathrm{M}$ nas SUVs.

NFX na presença e ausência de PC foi titulada com o complexo Cu:Phen e os espectros de fluorescência foram obtidos em cada tampão. Os resultados são apresentados na Fig. 5.7. Observa-se, a cada espectro obtido em concentrações crescentes de $\mathrm{Cu}$ :Phen, uma diminuição da intensidade de fluorescência, sem deslocamento do pico, característica de supressão de fluorescência devido à presença do complexo de cobre(II) como supressor. Na ausência de PC, o pico de fluorescência da NFX manteve-se em torno de $406 \mathrm{~nm}$ para cada tampão, já com PC o pico deslocou-se para $420 \mathrm{~nm}$ em ambos tampões, sugerindo associação às vesículas. De fato, no caso da associação de NFX com micelas de SDS, já tinha sido observado o deslocamento de 407 para $432 \mathrm{~nm}$ [Muniz et al., 2014].

Ao fazermos uma simples comparação qualitativa dos dois gráficos de supressão, vemos que tanto em PB como em PBS há um mesmo comportamento, deslocamento do pico e supressão, intuindo que não há influência significativa da força iônica do tampão na associação de Cu:Phen com NFX, tanto na ausência de PC (Fig. 5.7, ( $\left.\mathrm{a}_{1}\right)$ e ( $\left.\mathrm{a}_{2}\right)$ ) quanto na presença de PC (Fig. 5.7, $\left(\mathrm{b}_{1}\right)$ e ( $\left.\mathrm{b}_{2}\right)$ ). Acontece um mesmo comportamento dos espectros para cada tampão, sugerindo que não há diferença significativa no uso de PB ou PBS para o estudo da influência de PC na interação NFX com $\mathrm{Cu}$ :Phen. Estas observações qualitativas têm que ser confirmadas com uma análise quantitativa. 

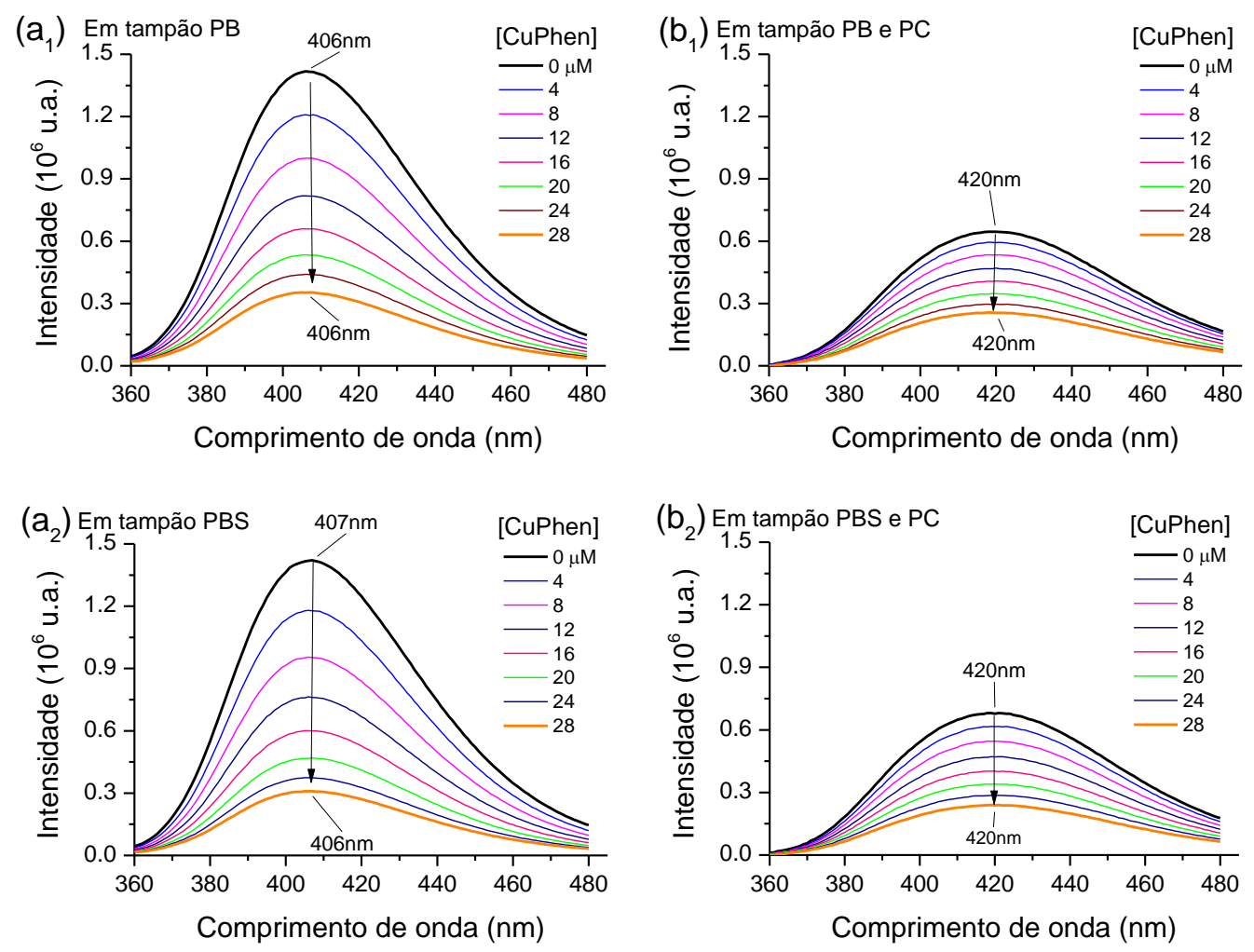

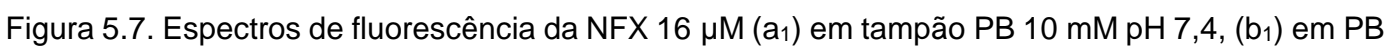

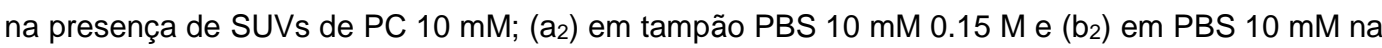
presença de PC $10 \mathrm{mM}$, subtraindo previamente o espalhamento. Titulação com Cu:Phen. Excitação em $330 \mathrm{~nm}$.

A Fig. 5.8 apresenta a variação em $413 \mathrm{~nm}$ da fluorescência da NFX em SUVs, em função da concentração do complexo para cada tampão. Esses resultados serão analisados de acordo com o modelo de associação adequado.

Nas Figs. $5.8\left(a_{1}\right)$ e $\left(a_{2}\right)$ estão apresentados os gráficos de Stern-Volmer para a supressão. Tanto em PB quanto em PBS o gráfico não é linear, apresentando curvatura em direção ao eixo vertical. As curvas em ausência e em presença de SUVs não estão sobrepostas, sugerindo que a presença das vesículas altera a associação de $\mathrm{Cu}$ :Phen a NFX. Utilizando o modelo de dois estados (Eq. 4.2) para ajustar as curvas da Fig. $5.8\left(\mathrm{~b}_{1}\right)$ e $\left(\mathrm{b}_{2}\right), \operatorname{com} F_{\infty}=0$ e $c_{L}=16 \mu \mathrm{M}$, foram obtidas as seguintes constantes de associação:

$K_{b}=1,6 \times 10^{5} \mathrm{M}^{-1}$, em $\mathrm{PB}$, e $K_{b}{ }^{P C}=0,7 \times 10^{5} \mathrm{M}^{-1}$, com vesículas de PC. $K_{b}=2,1 \times 10^{5} \mathrm{M}^{-1}$, em PBS, e $K_{b}{ }^{P C}=0,8 \times 10^{5} \mathrm{M}^{-1}$, com vesículas de PC,

A diferença não é significativa para os casos com PC. Além disso, estas constantes são muito menores do que as obtidas em micelas de $\operatorname{SDS}\left(K_{b}{ }^{S D S}=6,8 \times\right.$ $\left.10^{6} \mathrm{M}^{-1}\right)$. Conclui-se que, os tampões utilizados, não alteram significativamente a 
formação do complexo $\mathrm{Cu}$ :Phen:NFX nas vesículas e que as micelas têm uma influência maior $\left(\mathrm{K}_{\mathrm{b}} \sim 10^{6}\right)$ na formação do complexo do que as vesículas de PC $\left(\mathrm{K}_{\mathrm{b}} \sim 10^{5}\right)$. Como os resultados obtidos em PBS apresentaram uma $\mathrm{K}_{\mathrm{b}}$ levemente maior do que apenas em PB, todas as seguintes experiências foram feitas em PBS.
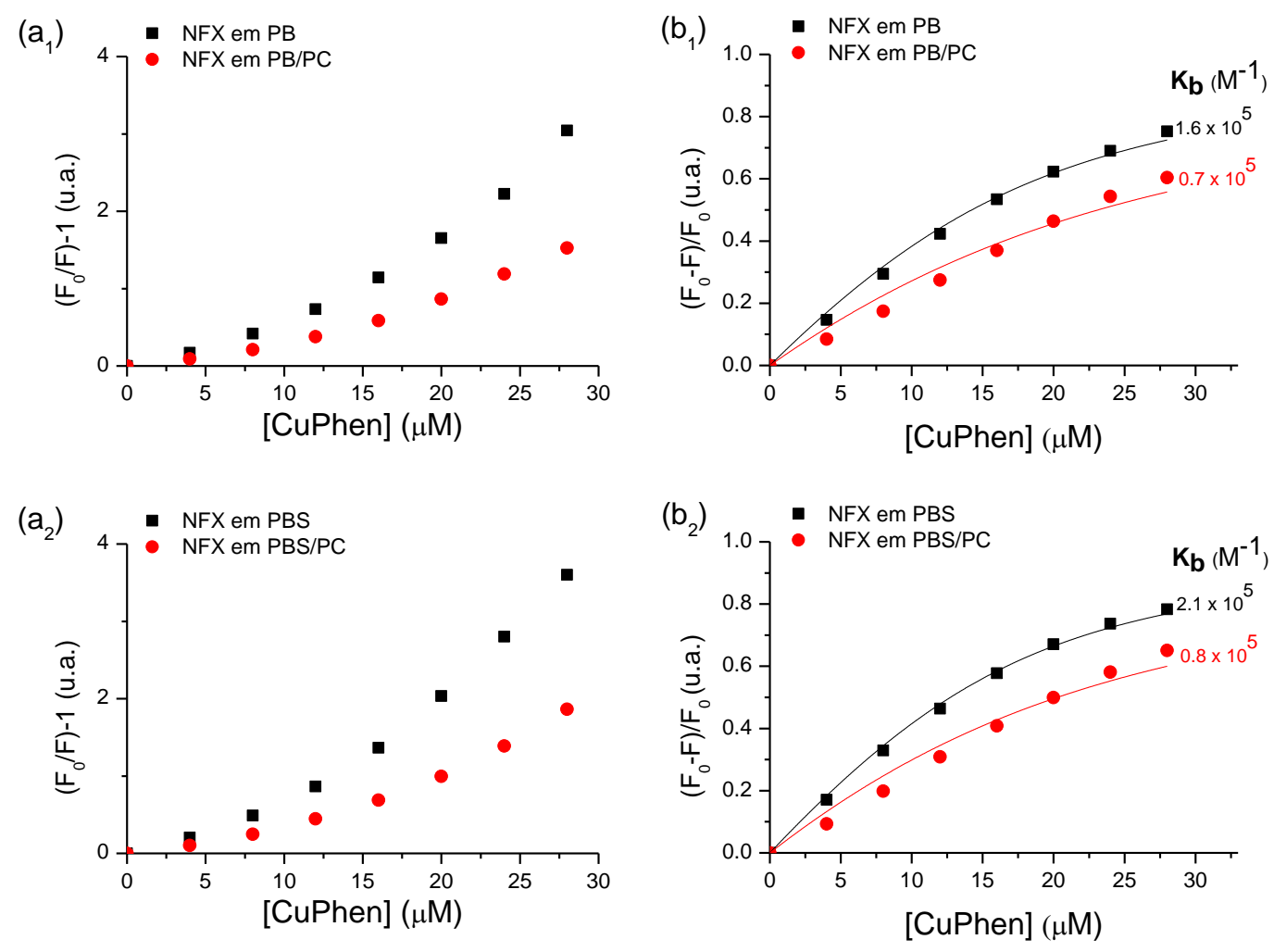

Figura 5.8. Fluorescência da NFX (em $413 \mathrm{~nm}$ ) como função da concentração de Cu:Phen, em SUVs de PC em Pb e em PBS. (a1) e (a2) Gráficos de Stern-Volmer. (b1) e (b2) Variação da fluorescência normalizada à máxima variação (completa supressão). Linha solida: curva de ajuste por mínimos quadrados, usando Eq. 4.2.

\section{2 .2}

\section{Vesículas unilamelares pequenas de fosfatidilcolina de ovo e ácido esteárico}

Nesta seção estudamos a interação de NFX com o complexo $\mathrm{Cu}$ :Phen na presença de SUVs com diferentes proporções de SA em relação a PC. Titulamos as soluções com o complexo de $\mathrm{Cu}$ :Phen, para observarmos a supressão de fluorescência estacionária. Como controle, utilizamos a titulação da solução em ausência de vesículas. 
Os espectros de fluorescência da NFX em PC/SA, titulada com o complexo $\mathrm{Cu}:$ Phen, foram obtidos, em duplicata, utilizando-se diferentes proporções de SA. Os resultados das duas séries de medidas foram muito semelhantes e na Fig. 5.9 são apresentados os resultados de uma das séries.

Nesses gráficos podemos comparar Cu:Phen interagindo com NFX em presença de SUVs de PC $(10 \mathrm{mM})$ preparadas em quatro diferentes proporções de SA: (a) na ausência de SA, (b) na presença de SA $2 \mathrm{mM}$, (c) na presença de SA $4 \mathrm{mM}$, e (d) na presença de SA 6 mM. Observa-se que, à medida que a concentração de SA aumenta, o pico de fluorescência da NFX é deslocado de $413 \mathrm{~nm}$ (sem SA) até $422 \mathrm{~nm}$ (SA 60\%). Isto sugere maior penetração de NFX dentro das vesículas ao aumentar a concentração de SA nas SUVs. Ao titular com Cu:Phen, observa-se a diminuição da intensidade de fluorescência, sem deslocamento do pico, característica de supressão de fluorescência devido à formação do complexo ternário $\mathrm{Cu}: P h e n: N F X$. Também se observa nos espectros que a supressão é cada vez menor para concentrações crescentes de SA.

(a) $0 \% \mathrm{SA}$

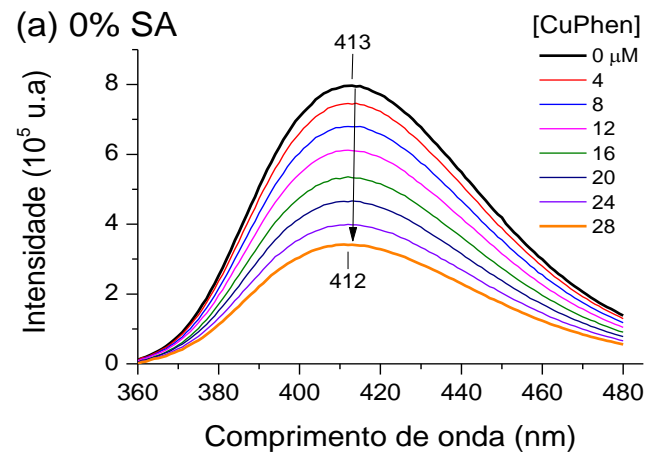

(c) $40 \% \mathrm{SA}$

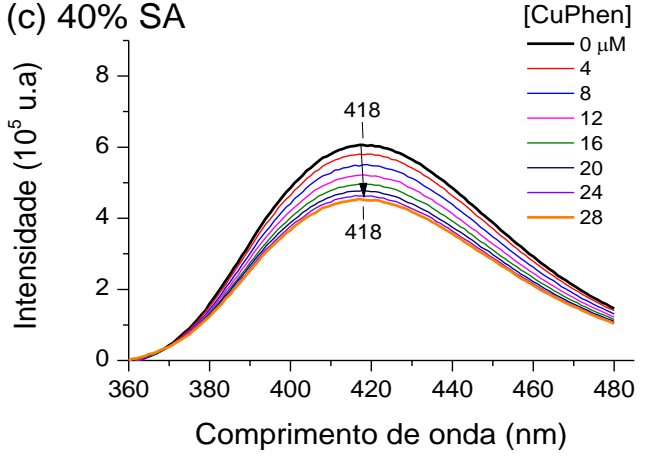

(b) $20 \% \mathrm{SA}$

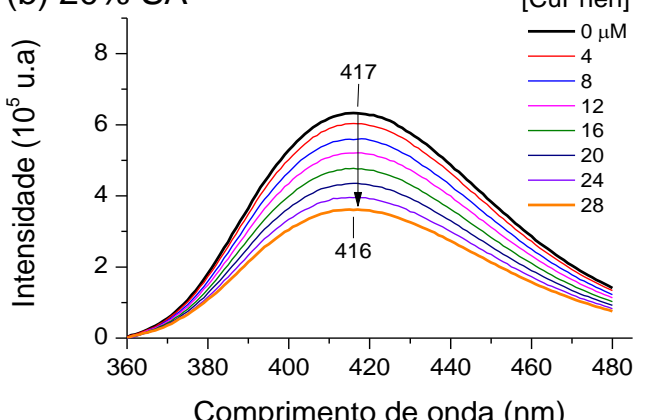

(d) $60 \% \mathrm{SA}$

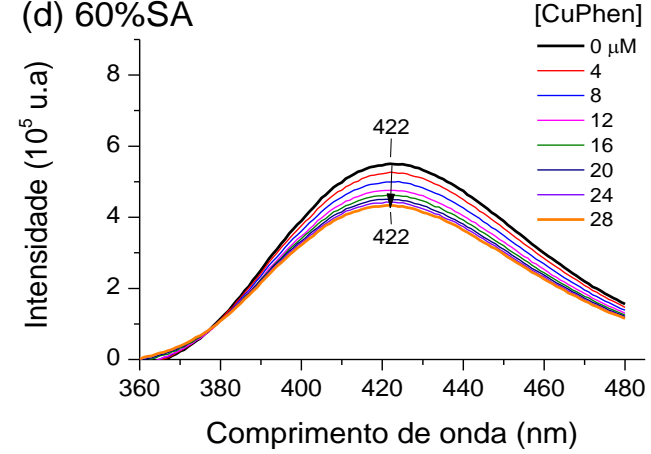

Figura 5.9. Espectros de fluorescência da NFX $16 \mu \mathrm{M}$ com PC e SA (a) 0 mM, (b) 2 mM, (c) 4 mM e (d) $6 \mathrm{mM}$ subtraindo o espectro do espalhamento. Todas as medidas foram em tampão PBS titulando com Cu:Phen. Excitação em $330 \mathrm{~nm}$. 
Uma comparação qualitativa dos graus de supressão, como porcentagem de fluorescência suprimida, indica que, em [Cu:Phen $]=28 \mu \mathrm{M}$, a fluorescência decai: SA 0 mM: 57\%, SA 2 mM: 31\%, SA 4 mM: 25\%, SA 6 mM: 21\%. Podemos então perceber que a supressão é menor à medida que a concentração de SA aumenta. Isto indica uma menor associação de NFX ao complexo Cu:Phen quando a porcentagem de SA nas vesículas é maior. SA parece restringir a associação de $\mathrm{Cu}$ :Phen com NFX.

Essas medidas, assim como todas, foram repetidas pelo menos mais de uma vez, verificando que elas seguem a mesma tendência.

Em continuação, são apresentadas as variações da fluorescência da NFX em 416 nm, em SUVs de PC/SA, como função da concentração do complexo (Fig. 5.10).
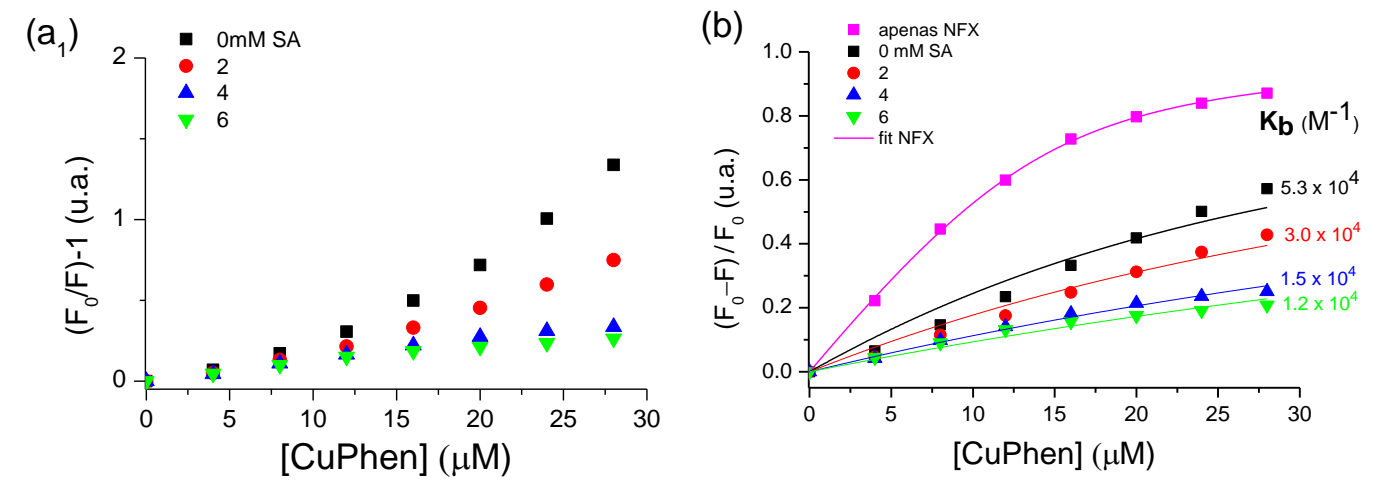

Figura 5.10. Fluorescência da NFX como função da concentração de Cu:Phen, em SUVs de PC com diferentes proporções de SA. (a) Gráfico de Stern-Volmer. (b) Variação da fluorescência normalizada à máxima variação (completa supressão). Linha solida: curva de ajuste por mínimos quadrados, usando Eq. 4.2. Curva magenta: NFX em PBS. Pico de análise em 417 nm.

A Fig. 5.10 (a) apresenta as curvas de Stern-Volmer, que são não lineares. No entanto, utilizando o modelo de dois estados (Eq. 4.2), com $F_{\infty}=0$ e $\mathrm{c}_{\mathrm{L}}=16 \mathrm{mM}$, os dados experimentais em 417 nm (Fig. 5.9 (b)) são ajustados com as constantes de ligação apresentadas abaixo. As constantes são próximas entre si, mas o modelo de 2 estados apresentou um ajuste pobre os pontos experimentais:
(a) para SA $0 \mathrm{mM} K_{b}=5,4 \times 10^{4} \mathrm{M}^{-1}$,
(b) para SA $2 \mathrm{mM} K_{b}=2,8 \times 10^{4} \mathrm{M}^{-1}$,
(c) para SA $4 \mathrm{mM} K_{b}=1,6 \times 10^{4} \mathrm{M}^{-1}$,
(d) para SA $6 \mathrm{mM} K_{b}=1,2 \times 10^{4} \mathrm{M}^{-1}$. 
Estas constantes são menores do que as obtidas em PB e PBS. Destas variações da intensidade de fluorescência, podemos observar que, em vesículas de lecitina com SA, a NFX apresenta menor supressão da fluorescência para concentrações maiores de SA. Isto indica que a interação do complexo metálico com a NFX associada às vesículas é tanto menor quanto maior a porcentagem de ácido esteárico. A análise quantitativa também indica que SA restringe a associação de $\mathrm{Cu}:$ Phen com NFX.

\section{2 .3}

\section{Vesículas unilamelares pequenas de fosfatidilcolina de ovo e SDS}

Nesta seção trabalhamos com vesículas mistas de PC e SDS ao invés de PC e ácido esteárico. Titulamos com o complexo de Cu:Phen a solução de NFX em presença das vesículas, para observarmos as mudanças nos espectros de fluorescência estacionária. Como controle, utilizamos a solução de NFX sem vesículas de PC.

Os espectros de fluorescência da NFX em PC com SDS, titulada com o complexo $\mathrm{Cu}$ :Phen foram obtidos utilizando diferentes proporções de SDS. Os resultados são apresentados na Fig. 5.11. Observa-se que, à medida que a concentração de SDS aumenta, o pico de fluorescência da NFX é deslocado de $413 \mathrm{~nm}$ (sem SDS) até $431 \mathrm{~nm}$ (SDS 60\%). Isto sugere maior penetração de NFX dentro das vesículas ao aumentar a concentração de SDS nas SUVs.

Nesses gráficos podemos comparar Cu:Phen interagindo com NFX em presença de SUVs de PC preparadas em quatro diferentes proporções de SDS: (a) na ausência de SDS, (b) na presença de SDS $2 \mathrm{mM}$, (c) $4 \mathrm{mM}$, e (d) $6 \mathrm{mM}$. Aumentando-se a concentração de $\mathrm{Cu}$ :Phen, observa-se a diminuição da intensidade de fluorescência, sem deslocamento do pico, característica de supressão de fluorescência devido à formação do complexo ternário $\mathrm{Cu}$ :Phen:NFX (Fig. 5.11). Também se observa nos espectros que a supressão é cada vez maior para concentrações crescentes de SDS.

Os espectros também mostram que, contrariamente do observado nos casos anteriores, à medida que a proporção de SDS aumenta a supressão é cada vez maior. 
(a) $0 \% \mathrm{SDS}$

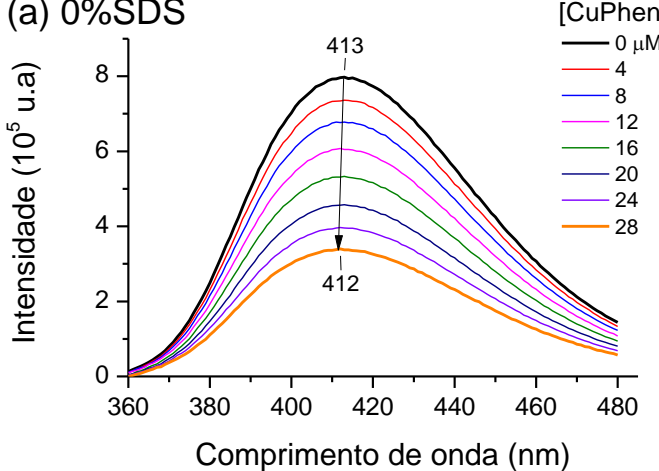

(c) $40 \% \mathrm{SDS}$

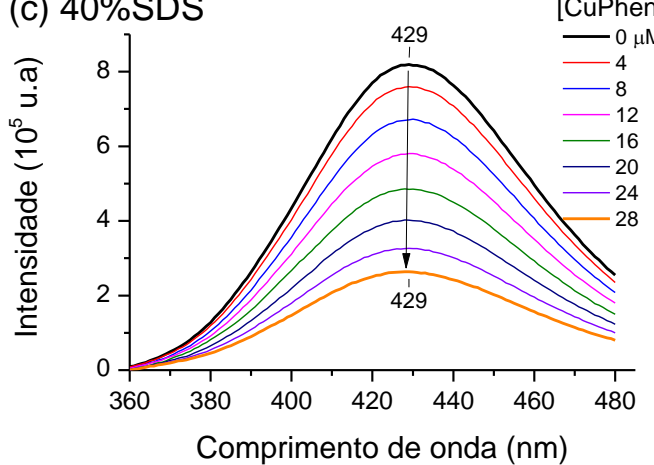

(b) $20 \% \mathrm{SDS}$

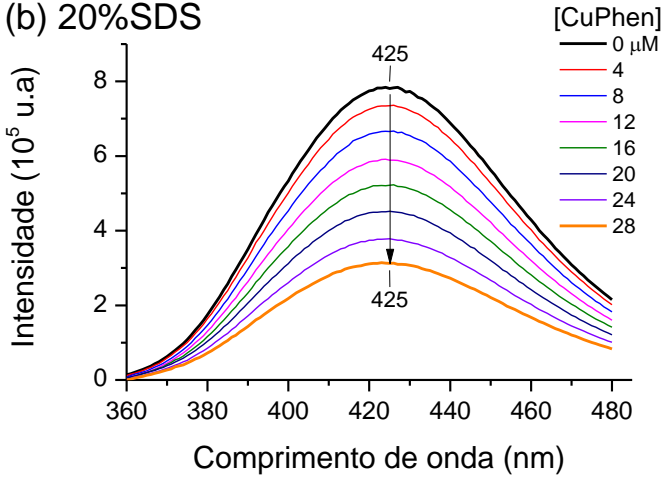

(d) $60 \%$ SDS $\quad 431 \quad$ [CuPhen]

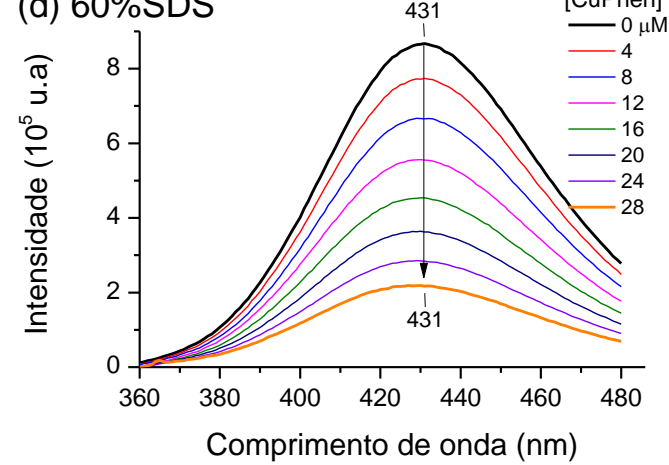

Figura 5.11. Espectros de fluorescência da NFX $16 \mu \mathrm{M}$ com PC e SDS (a) 0 mM, (b) $2 \mathrm{mM}$, (c) $4 \mathrm{mM}$ e (d) $6 \mathrm{mM}$, subtraindo o espectro do espalhamento. Todas as medidas foram em tampão PBS titulando com Cu:Phen. Excitação em $330 \mathrm{~nm}$.

Nesses gráficos podemos comparar qualitativamente os quatro casos: NFX interagindo com $\mathrm{Cu}$ :Phen (a) na ausência de SDS, (b) na presença de SDS $2 \mathrm{mM}$, (c) SDS $4 \mathrm{mM}$, e (d) SDS $6 \mathrm{mM}$. A comparação como porcentagem de fluorescência suprimida em [Cu:Phen] $=28 \mu \mathrm{M}$, mostra que a fluorescência decai: SDS 0 mM, 57\%; SDS 2 mM, 60\%; SDS 4 mM, 68\%; SDS 6 mM, 76\%, ou seja, a supressão final é cada vez maior à medida que a concentração de SDS nas vesículas aumenta. Isto sugere maior associação do complexo à NFX quando a concentração de SDS é maior.

A Fig. 5.12 apresenta a variação da fluorescência em $423 \mathrm{~nm}$ de NFX em SUVs de PC com SDS, como função da concentração de $\mathrm{Cu}: P h e n$. 

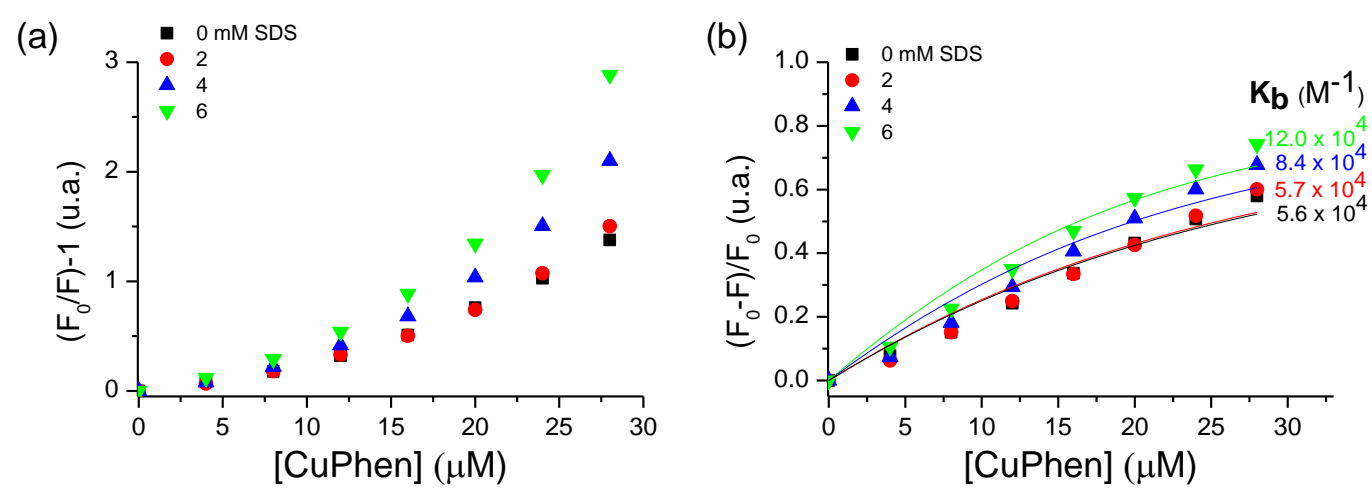

Figura 5.12. Fluorescência da NFX (em $422 \mathrm{~nm}$ ) como função da concentração de Cu:Phen, em SUVs de PC com diferentes proporções de SDS. (a) Gráficos de Stern-Volmer. (b) Variação da fluorescência normalizada à máxima variação (completa supressão). Linha solida: curva de ajuste por mínimos quadrados, usando Eq. 4.2.

A Fig. 5.12 (a) apresenta as curvas de Stern-Volmer, as quais são não lineares. No entanto, utilizando a Eq. 4.2, $\operatorname{com} F_{\infty}=0$ e $\mathrm{c}_{\mathrm{L}}=16 \mathrm{mM}$, as curvas apresentaram um ajuste dos dados experimentais em $422 \mathrm{~nm}$ (Fig. 5.11 (b)) com as constantes de ligação apresentadas na figura. Estas constantes são muito menores do que as obtidas em PB e PBS (Fig. 5.7), mas são maiores do que as encontradas com SA (Fig. 5.10). Podemos observar, destas variações da intensidade de fluorescência, que em vesículas de PC com SDS a NFX apresenta maior supressão da fluorescência para concentrações maiores de SDS. Isto poderia indicar que a interação do complexo metálico com a NFX associada às vesículas é maior quanto maior a porcentagem de SDS. Provavelmente, como verificado em micelas de SDS, o surfactante aniônico está favorecendo a associação do complexo $\mathrm{Cu}$ :Phen com a NFX.

Neste estudo espectroscópico de NFX e a formação de complexos mistos de $\mathrm{Cu}:$ Phen em SUVs, podemos ver que, em comparação com o observado com as micelas de SDS, as vesículas (neutras, sem SA nem SDS) tem menor influência $\left(\mathrm{K}_{\mathrm{b}} \sim 10^{5}\right)$ na formação do complexo. A presença do surfactante aniônico SDS favoreceu a associação do complexo com a NFX, mesmo sendo menor esta associação do que a encontrada nas micelas de SDS.

Quando SA foi adicionado, observou-se menor associação à medida que utilizávamos proporções maiores de SA, provavelmente devido a uma blindagem eletrônica. Com o SDS, a interação incrementou notavelmente a associação deslocando o pico até $431 \mathrm{~nm}$, semelhante ao que aconteceu para NFX em micelas de SDS [Muniz et al., 2014]. No caso com SA, o pico se deslocou apenas até 
$422 \mathrm{~nm}$, sugerindo menor ligação do fármaco fluorescente às SUVs de PC com SA do que às micelas de SDS. Portanto, utilizando este procedimento de preparação de PC, verificamos que as SUVs favorecem também a formação do complexo quando utilizamos SDS e dificulta a formação ao usar SA. Pela complexidade das vesículas, pode-se estudar em trabalhos posteriores um melhor procedimento a fim de melhorar esta formação do complexo dentro das vesículas de PC.

\section{3 Interação da norfloxacina com DNA}

$\mathrm{Na}$ literatura há inúmeros trabalhos de investigação da interação de FQs com DNA, em geral, utilizando modificações nos espectros de absorção do DNA ou do fármaco. Esses trabalhos são em geral realizados em soluções de força iônica alta (da ordem de $0.2 \mathrm{M}$ ). Como os grupos fosfato da dupla hélice de DNA são carregados negativamente, e foram detectadas interações fortes das FQs com grupos aniônicos em micelas e membranas aniônicas, vamos testar a associação da norfloxacina com DNA introduzindo duas modificações em relação às descritas na literatura: (a) força iônica mais baixa $(5 \mathrm{mM})$ e (b) utilização da fluorescência da norfloxacina como marcador intrínseco da interação.

Neste trabalho preliminar, titulamos com DNA uma solução contendo NFX em concentração fixa (tampão Tris 5 mM, pH 7.4) para observarmos as mudanças nos espectros de absorção, fluorescência estacionária e resolvida no tempo. O comprimento de onda de excitação utilizado foi sempre de $330 \mathrm{~nm}$.

Foram preparadas soluções estoque de DNA $1 \mathrm{mg} \mathrm{ml}^{-1}$ (para cálculo da concentração molar de DNA foi utilizado o coeficiente de absorção molar $\varepsilon_{260 \mathrm{~nm}}=$ $6600 \mathrm{M}^{-1} \mathrm{~cm}^{-1}$, Reichmann, 1954). A concentração de norfloxacina foi determinada espectrofotometricamente usando o coeficiente de absorção molar $\varepsilon_{273 \mathrm{~nm}}=37500 \mathrm{M}^{-1} \mathrm{~cm}^{-1}$ (para a NFX, em pH 7,4) e de NFX 1,6 mM, esta última diluída diretamente na cubeta contendo Tris para obter $8 \mu \mathrm{M}$ de NFX. Em seguida foram adicionadas alíquotas da solução de DNA e os espectros eram registrados a cada adição. 


\section{Espectros de absorção de DNA em presença de NFX}

A Fig. 5.13 mostra os espectros de absorção de concentrações crescentes de DNA em presença de NFX ( $8 \mu \mathrm{M})$, já subtraídos do espectro de NFX. Obtém-se que a intensidade da absorbância é proporcional à concentração de DNA, mostrando que a presença de NFX não muda a absorção de DNA. Vemos também que não há mudança da forma do espectro nem deslocamento do pico (comparar com espectro tracejado, de DNA em ausência de NFX), o que sugere fraca ou nenhuma interação.

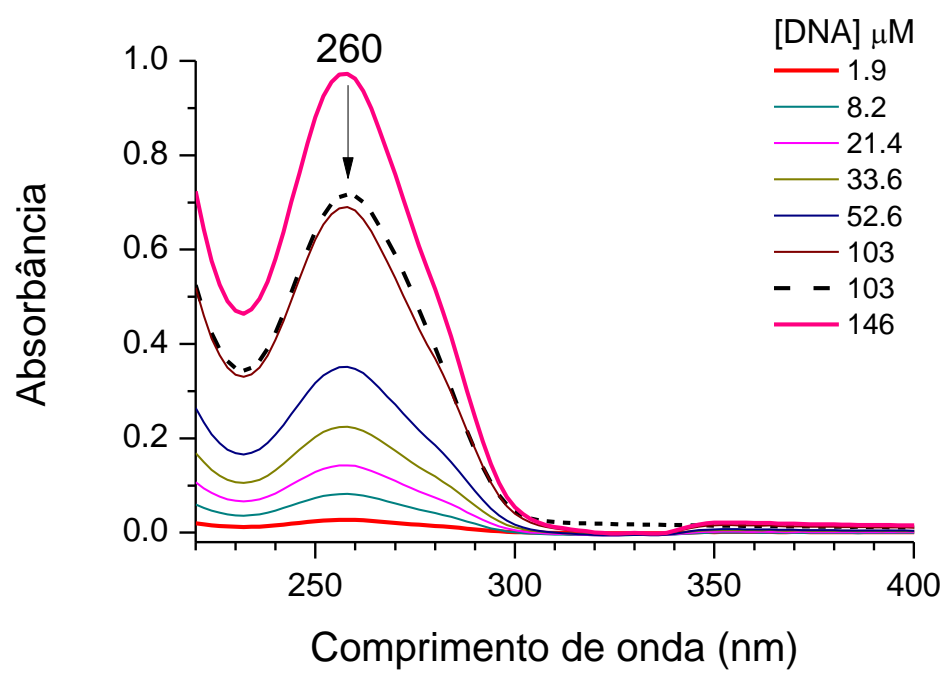

Figura 5.13. Espectros de absorção de DNA em NFX $8 \mu \mathrm{M}$, subtraídos do espectro da NFX para diferentes concentrações. Linha tracejada: espectro de DNA puro $103 \mu \mathrm{M}$.

\section{Estudo da interação com DNA através de fluorescência da NFX}

Os espectros de fluorescência da NFX (Fig. 5.14) também foram obtidos para concentrações crescentes de DNA. É possível observar uma supressão da fluorescência com pico em 407 nm, característico da NFX em pH 7,4.

A Fig. 5.15 apresenta o gráfico de Stern-Volmer para a variação da fluorescência da NFX (pico em $407 \mathrm{~nm}$ ) em função da concentração de DNA. Observou-se um comportamento linear a partir de [DNA] $=20 \mu \mathrm{M}$. De acordo com o modelo de Stern-Volmer para supressão estática, o coeficiente angular do gráfico é a própria constante de associação $\left(\mathrm{K}_{\mathrm{b}}\right)$. 


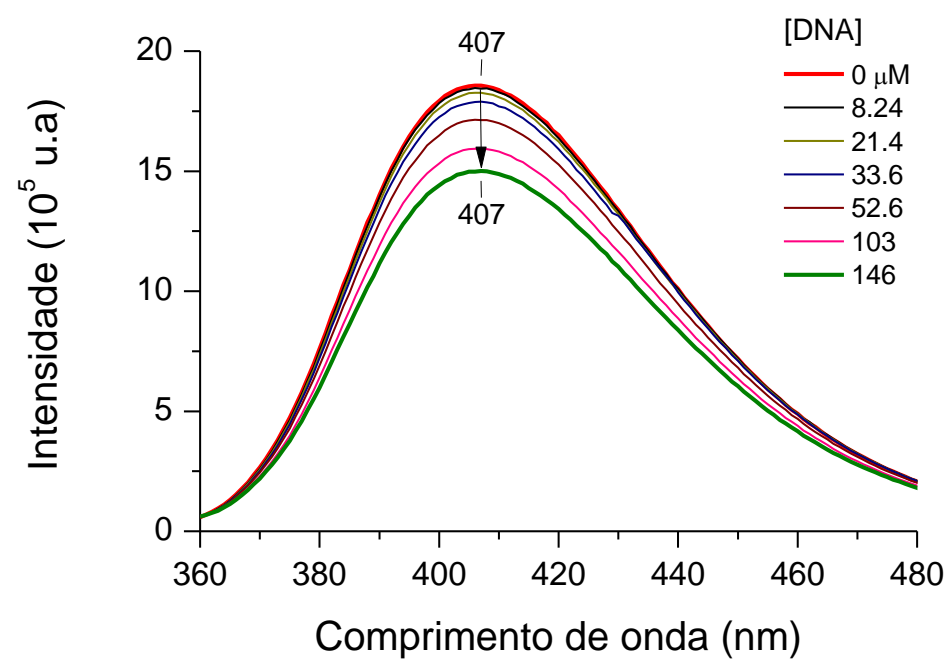

Figura 5.14. Espectros de fluorescência da NFX $8 \mu \mathrm{M}$, em tampão TRIS, e o efeito da titulação com DNA. Excitação em $330 \mathrm{~nm}$.

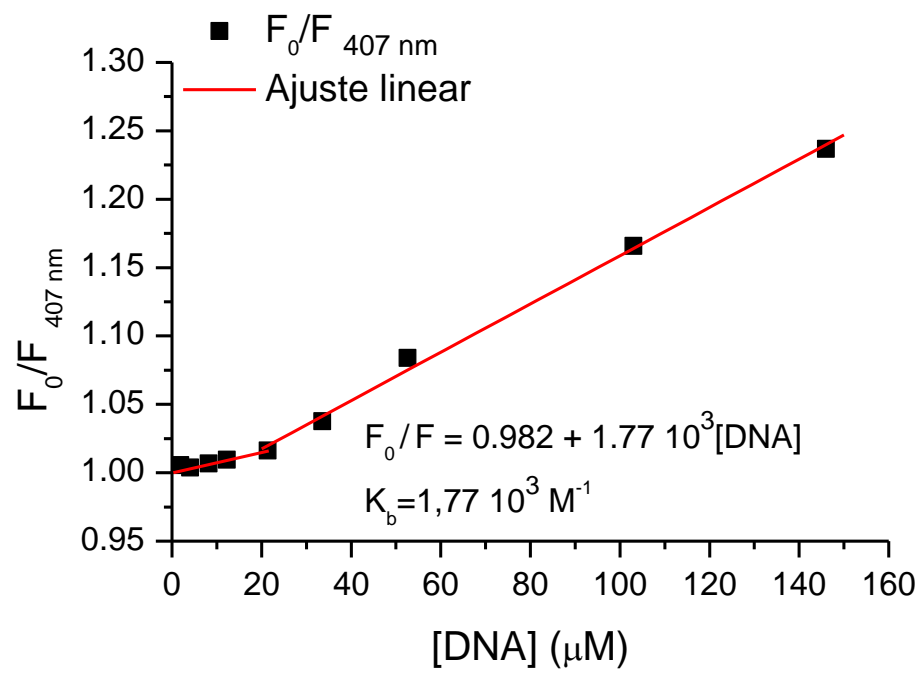

Figura 5.15. Gráfico de Stern-Volmer para a supressão da fluorescência da NFX como função da concentração do DNA. A linha sólida representa a curva de ajuste para a obtenção da constante $\mathrm{K}_{\mathrm{b}}$.

Ajustando os pontos experimentais à Equação de Stern-Volmer, obteve-se uma constante de associação, $\mathrm{K}_{\mathrm{b}}=1,77 \times 10^{3} \mathrm{M}^{-1}$. Essa constante é uma ordem de grandeza menor do que a encontrada por Zhanguang et al., 2007 $\left(\mathrm{K}_{\mathrm{b}}=1,7 \times 10^{4} \mathrm{M}^{-1}\right)$ usando a técnica de espalhamento ressonante de luz, mas é da mesma ordem que a encontrada por Patel e Patidar, 2014; utilizando absorção UVVis, $\mathrm{K}_{\mathrm{b}}=1,13 \times 10^{3} \mathrm{M}^{-1}$.

Portanto, pode-se concluir que há pouca interação da NFX com o DNA, mesmo em condições de força iônica bastante baixa, sugerindo que a interação não é dominada por forças eletrostáticas. 


\section{4 \\ Interação de fluorquinolonas com nanopartículas de ouro}

Nesta seção mostraremos a interação de $\mathrm{FQs}$ com nanopartículas de ouro sintetizadas via ablação a laser, as quais vamos denominar nanocompósitos de ouro, AuNCs, já que contêm uma camada de carbonóides na sua superfície [Del Rosso, 2015]. Para comparação também utilizamos nanopartículas de ouro sintetizadas por via química.

Todos os experimentos de fluorescência estacionária realizados com AuNCs foram feitos excitando-se a NFX em $330 \mathrm{~nm}$, caso contrário será indicado na descrição da seção correspondente.

\section{4 .1}

\section{Interação de NFX, CFX e LFX com AuNCs}

Nesta primeira parte titulamos com AuNCs uma solução de NFX $8 \mu \mathrm{M}$ em tampão fosfato $2 \mathrm{mM}, \mathrm{pH} 7,8$, para observarmos as mudanças nos espectros de extinção, fluorescência estacionária e resolvida no tempo.

Para o cálculo da concentração de AuNCs usadas na titulação, fizemos as contas considerando que a absorbância é 1 em $518 \mathrm{~nm}$ quando a concentração de AuNCs é $30 \mathrm{mg} \mathrm{L}^{-1}$, ou $30 \mathrm{ppm}$ [Del Rosso, 2016]. Para obter o coeficiente de extinção molar $\left(\mathrm{M}^{-1} \mathrm{~cm}^{-1}\right)$, calculamos o número de partículas de ouro em um grama, usando a densidade do ouro, $19,3 \mathrm{~g} \mathrm{~cm}^{-3}$, e o volume de uma partícula de ouro de $5 \mathrm{~nm}$ de diâmetro. Com isto, encontrou-se que $\varepsilon_{518 \mathrm{~nm}}=2,5 \times 10^{7} \mathrm{M}^{-1} \mathrm{~cm}^{-1}$, para nanopartículas com $5 \mathrm{~nm}$ de diâmetro médio. Isto está de acordo com o encontrado por Griffin et al., 2009; cujo valor é próximo para nanopartículas com diâmetro médio de $6,5 \mathrm{~nm}$.

Absorção e fluorescência

A Fig. 5.16 (a) mostra o espectro de extinção dos AuNCs em tampão $\mathrm{PO}_{4}$, 2 mM, pH 7,8 com pico em 520 nm, e a Fig. 5.16 (b) mostra a absorbância da NFX 8,0 $\mu \mathrm{M}$ ao titular com quantidades crescentes de AuNCs. A subtração desses espectros (b) e (a) foi com a finalidade de detectar as modificações espectrais da NFX devido aos AuNCs. 

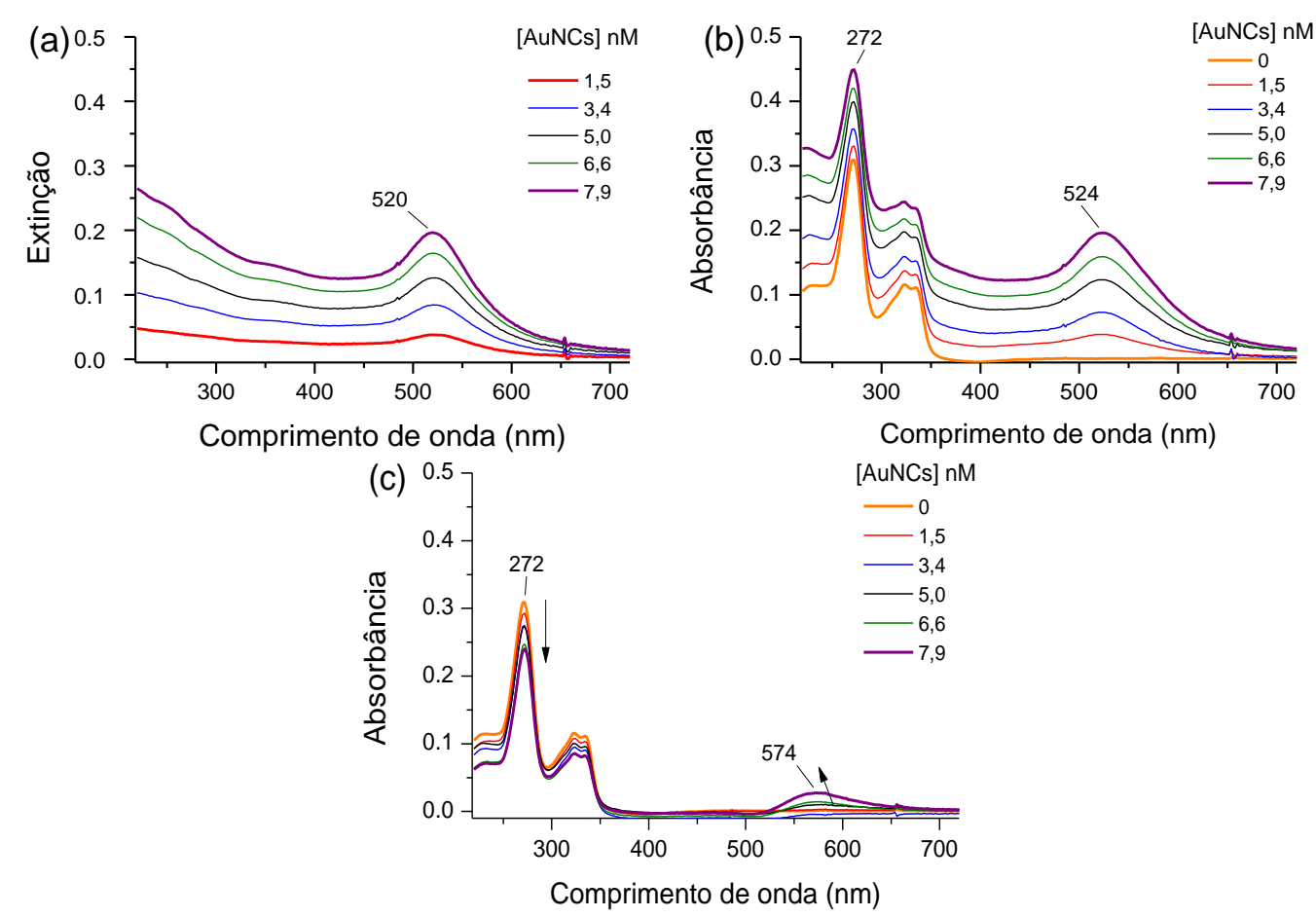

Figura 5.16. Espectros de absorção/extinção de soluções tituladas com AuNCs. (a) apenas em tampão $\mathrm{PO}_{4}, 2$ mM, pH 7,8; (b) NFX 8,0 $\mu \mathrm{M}$ no mesmo tampão; (c) subtração dos espectros: (b) - (a).

Observa-se, a partir da subtração de espectros, que a NFX modifica levemente os espectros de AuNCs (Fig. 5.16 (c), região de 500 a 650 nm). Podemos ver que existe uma leve interação de NFX com os AuNCs ao observar as mudanças na banda plasmônica $(500-700 \mathrm{~nm})$. Observa-se também uma diminuição da absorbância de NFX, sugerindo associação de NFX com AuNCs, que pode provocar desvios da linearidade entre absorbância e concentração (Lei de BeerLambert).

Para seguir com esses estudos passamos a estudar a fluorescência da NFX na presença dos AuNCs nessas condições. Os espectros de fluorescência da NFX também foram obtidos e a influência dos AuNCs foi estudada (Fig. 5.17 (a)). É possível perceber uma aparente supressão da fluorescência da NFX em $407 \mathrm{~nm}$.

No entanto há três correções que devem ser feitas: a correção por causa da diluição, já que as alíquotas da solução de AuNCs diluíram um pouco a NFX; a correção na intensidade da luz incidente $(330 \mathrm{~nm})$, que é absorvida em parte pela amostra até chegar ao centro da cubeta e na intensidade da luz emitida, que também é absorvida em parte pela amostra antes de deixar a cubeta. 

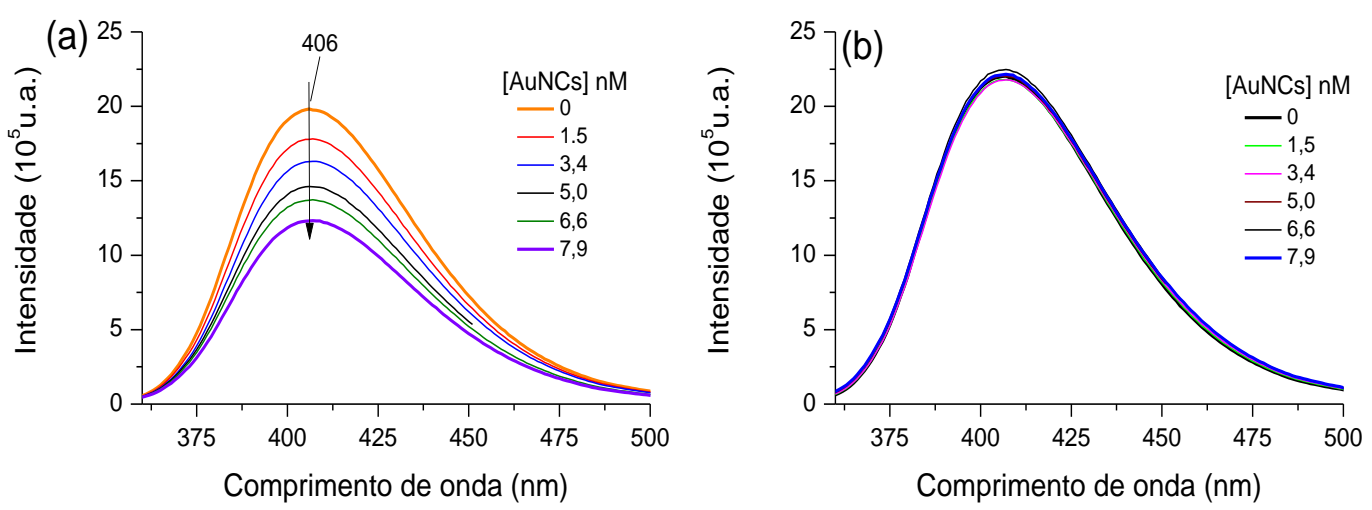

Figura 5.17. (a) Espectros de fluorescência da NFX em tampão e o efeito da titulação com alíquotas de nanocompósitos de ouro. (b) Espectros de fluorescência da NFX corrigidos.

A expressão para essas correções é dada pela Eq. 4.5, com $\ell_{\mathrm{em}}=\ell_{\mathrm{exc}}=1,0 \mathrm{~cm}$.

Então, ao fazer as correções dos volumes e dos efeitos de filtro interno na excitação e na emissão, podemos ver que a supressão de fluorescência foi nula (Fig. 5.17 (b)).

Numa outra experiência, para verificar se os AuNCs apresentavam luminescência, fizeram-se medidas de fluorescência excitando em 510 nm, mas não foi observada luminescência alguma.

Durante a titulação com AuNCs foi analisado o decaimento da fluorescência da NFX. Uma rápida análise das curvas de decaimento na ausência e presença de concentrações crescentes de AuNCs (Fig. 5.18) mostrou que não há variação no tempo de vida quando aumentamos a concentração de AuNCs, mesmo em altas concentrações.

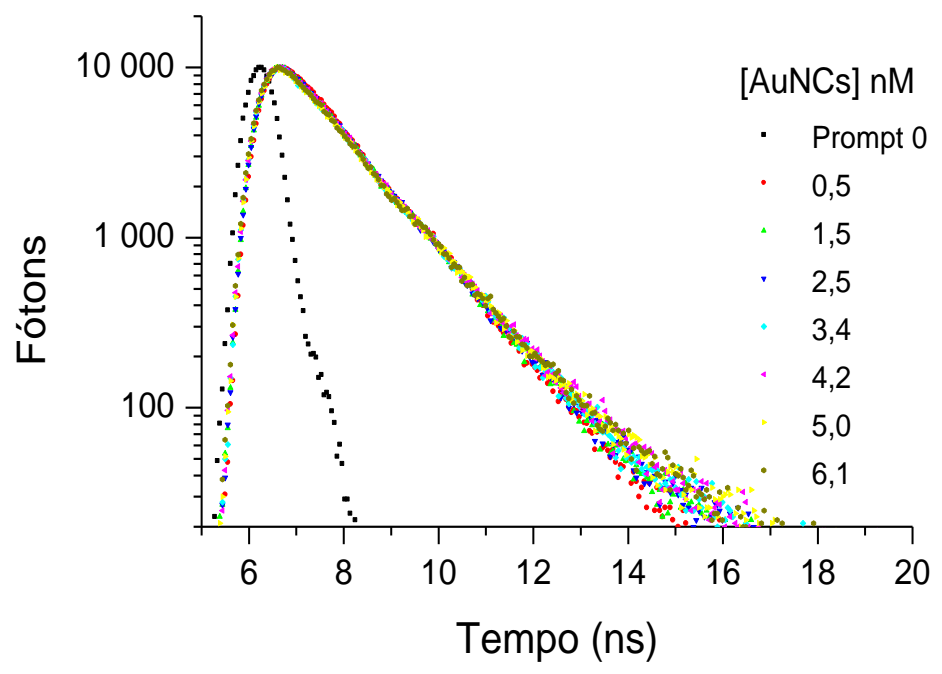

Figura 5.18. Decaimento da fluorescência da NFX em solução aquosa e a titulação com AuNCs. 
Portanto, desses resultados de absorção e fluorescência de titulação da NFX com os nanocompósitos de ouro, foi visto que:

- Não foi detectada fluorescência alguma de AuNCs em tampão fosfato $2 \mathrm{mM}$, ao excitar na banda plasmônica. Portanto, esses AuNCs não são fluorescentes, ou a sua fluorescência é desprezível.

- Observou-se uma aparente supressão de fluorescência da NFX causada por concentrações crescentes de AuNCs, que demonstrou ser inexistente ao introduzirmos as correções do efeito de filtro interno na excitação e na emissão, além da correção trivial pela leve diluição da amostra, mostrando assim a importância de considerar essas correções.

- Com respeito à experiência de fluorescência resolvida no tempo, as curvas de decaimento da fluorescência não mostraram mudança alguma na inclinação, indicando que não há variação no tempo de vida da NFX ao aumentarmos a concentração de AuNCs. Isto está de acordo com a ausência de supressão encontrada no experimento de fluorescência estacionária.

Em resumo, os AuNCs em tampão fosfato de baixa força iônica $(2 \mathrm{mM})$, pH 7,8, modificam levemente os espectros de absorção e fluorescência da NFX, onde a banda plasmônica dos AuNCs sofre um deslocamento batocrômico de $4 \mathrm{~nm}$.

\section{4 .2}

\section{Interação com AuNCs tratados com citrato}

A pesquisa relacionada com nanopartículas de ouro sintetizadas por ablação a laser vem se intensificando [Del Rosso et al., 2018; Del Rosso et al., 2016; Palazzo et al., 2017; Amjadi e Farzampour, 2013; Amendola et al., 2006]. Nesta seção utilizamos absorção UV-Vis e fluorescência para estudar as propriedades ópticas e os mecanismos de interação de FQs com os AuNCs.

Particularmente, investigamos a interação de CFX, NFX e LFX com os AuNCs em água e protegidos com citrato, para controlar a formação de aglomerados. Depois das FQs interagindo com os AuNCs, estudamos a liberação controlada do antibiótico da superfície dos AuNCs usando moléculas que contêm grupos tióis (-SH), já que estes se ligam fortemente à superfície dos AuNCs. Finalmente terminamos estudando a possível reversão ao estado inicial dos AuNCs. 


\section{Interação com ciprofloxacina}

Nesta primeira experiência utilizamos os AuNCs em água, sem o tratamento com citrato de sódio. Adicionamos CFX, $77 \mu \mathrm{M}$ à solução contendo os AuNCs em água. Observou-se uma mudança rápida de cor, de vermelho para roxo, com precipitação visível das nanopartículas. As medidas de absorbância (Fig. 5.19) mostram um rápido e pronunciado deslocamento batocrômico da banda plasmônica dos AuNCs de 518 para $578 \mathrm{~nm}$, chegando a $591 \mathrm{~nm}$ depois de meia hora, com alargamento da banda. Este deslocamento batocrômico assim como o hipocromismo indicam formação de aglomerados de AuNCs como resultado da interação da CFX com a superfície dos nanocompósitos.

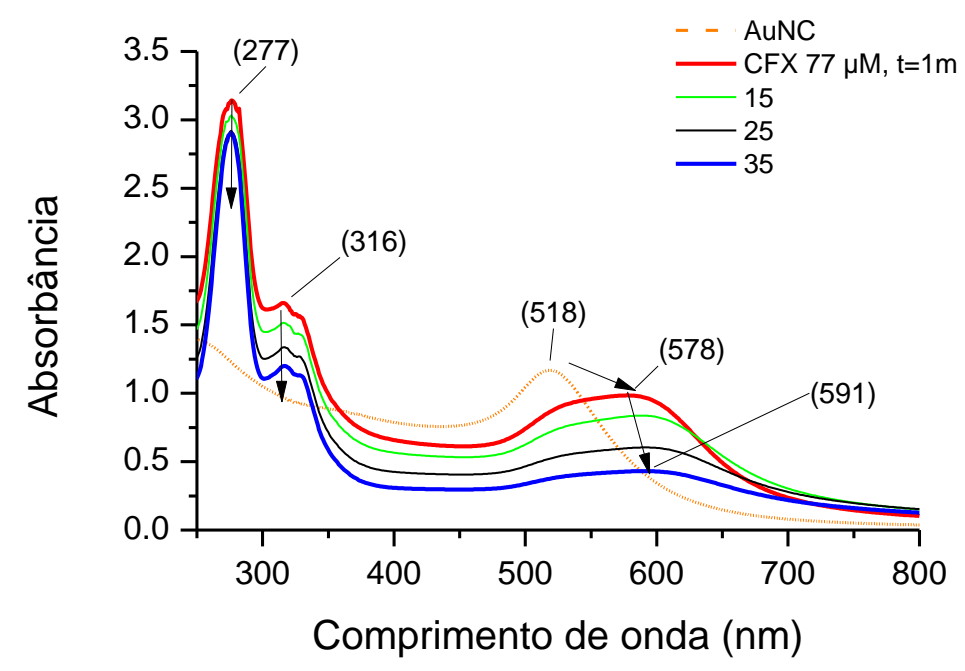

Figura 5.19. Evolução temporal dos espectros de extinção dos AuNCs depois de adicionar CFX $77 \mu \mathrm{M}$. (absorbância dos AuNCs A = 1,23 em 517 nm, caminho óptico de $1 \mathrm{~cm}$ )

Portanto, em água, a interação $\mathrm{CFX}$ com os AuNCs provoca rápida aglomeração. Para controlar esta aglomeração tentamos estabilizar os AuNCs com citrato de sódio.

\section{Interação com norfloxacina}

Para compararmos os efeitos da interação de FQs-AuNCs com os efeitos descritos na literatura em AuNPs preparadas por redução de $\mathrm{HAuCl}_{4}$ estabilizadas com citrato [Grace e Pandian, 2007], adicionamos citrato de sódio 0,1 $\mathrm{mM}$ aos AuNCs (AuNCs-citr), mesma concentração que a utilizada nessa referência, e obtivemos espectros de absorção/extinção antes e após a adição (Fig. 5.20). Não 
houve mudança no espectro dos nanocompósitos, mantendo-se a banda plasmônica centralizada em $518 \mathrm{~nm}$, indicando estabilização dos AuNCs ante adição direta do citrato. A Fig. 5.20 também inclui o espectro de NFX $40 \mu \mathrm{M}$ em água e a superposição com o espectro dos AuNCs-citr como controle, mostrando os picos característicos em pH 7,4 de 273 nm, 324 nm e 335 nm.

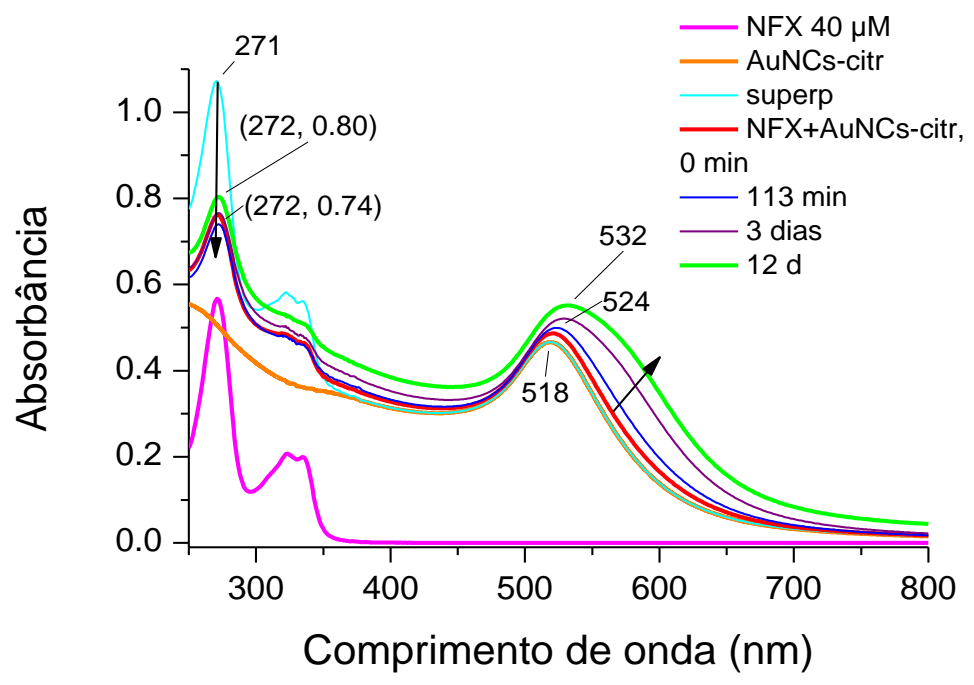

Figura 5.20. Espectros de absorção/extinção de NFX $40 \mu \mathrm{M}$ (magenta), AuNCs depois de tratar com $0,1 \mathrm{mM}$ de citrato (laranja) e evolução temporal dos espectros depois de adicionar NFX $40 \mu \mathrm{M}$. A superposição dos espectros de NFX e AuNCs também é mostrada, para comparação.

Em seguida, adicionamos NFX $40 \mu \mathrm{M}$ aos AuNCs-citr e obtivemos a evolução temporal dos espectros UV-Vis (Fig. 5.20). Observa-se, na região da banda plasmônica dos AuNCs-citr, um deslocamento batocrômico de 518 para $521 \mathrm{~nm}$ em hora e meia, chegando a $532 \mathrm{~nm}$ depois de 12 dias, muito mais lento do que o observado em ausência de citrato.

Este deslocamento batocrômico e incremento de intensidade da banda plasmônica sugerem interação de NFX com a superfície dos nanocompósitos mediante ligação. Neste caso de AuNCs tratados com citrato, a modificação na banda plasmônica foi bem menor do que no caso sem citrato (Fig. 5.19), mas com precipitação desprezível das nanopartículas indicando modificação da superfície sem aglomeração.

Na Fig. 5.20 o espectro ciano é a superposição (soma) dos espectros de NFX $40 \mu \mathrm{M}$ e de AuNCs-citr. Se comparamos essa superposição com os espectros dos AuNCs-citr ao adicionar NFX $40 \mu \mathrm{M}$ (vermelha e seguintes), podemos observar que a absorbância na região de NFX na presença de AuNCs é bem menor do que 
na ausência destas. Não estamos vendo toda a contribuição da NFX, possivelmente porque, estando NFX ligada à superfície dos AuNCs, ela estaria em parte oculta para o feixe de luz do espectrofotômetro. Isso será chamado aqui de "efeito sombra" dos AuNCs.

Na Fig. 5.21 mostramos a análise das modificações espectrais por subtração de espectros. Na Fig. 5.21 (a) observa-se o resultado de subtrair o espectro de AuNCs-citr dos espectros da Fig. 5.20 depois de adicionar NFX nos diferentes tempos. Na região da banda plasmônica (de 500 a $650 \mathrm{~nm}$ ) observa-se o crescimento da banda e deslocamento batocrômico. Como discutido no parágrafo anterior, na região das bandas de NFX (250 a $350 \mathrm{~nm}$ ) observa-se uma contribuição menor do que a esperada (comparar com o espectro de NFX $40 \mu \mathrm{M}$ ). Portanto o espectro UV-Vis detecta interação da NFX com os nanocompósitos em citrato.
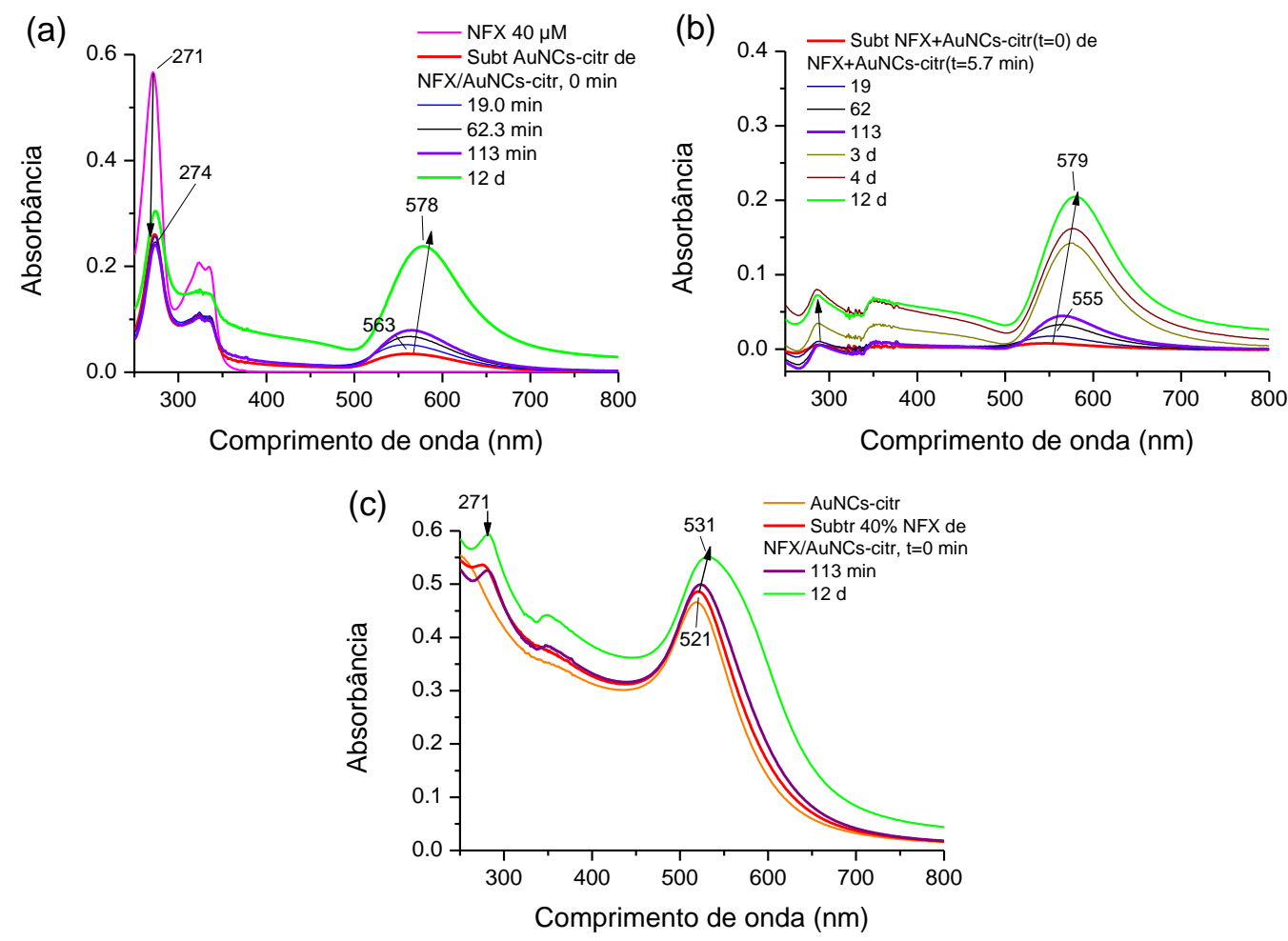

Figura 5.21. Análise dos espectros de absorção e extinção de NFX/AuNCs-citr mediante subtração entre espectros da Fig. 5.19: (a) espectros nos diferentes tempos subtraindo o espectro de AuNCs; (b) espectros nos diferentes tempos subtraindo o espectro inicial ( $\mathrm{t}=0)$; (c) espectros em diferentes tempos após subtrair $40 \%$ do espectro de NFX $40 \mu \mathrm{M}$.

Na Fig. 5.21 (b) podemos notar o efeito temporal da interação da NFX com os AuNCs ao subtrair o espectro inicial de NFX/AuNCs-citr dos espectros posteriores. Observa-se com maior claridade o aumento e deslocamento 
batocrômico da banda plasmônica. Um leve deslocamento dos picos correspondentes à NFX, devido provavelmente a mudanças no $\mathrm{pH}$ local, leva às ondulações observadas na região entre 250 e $350 \mathrm{~nm}$.

Na Fig. 5.20 (c)) vemos em 271 nm que a absorbância da NFX em solução contendo AuNCs é menos da metade do que em ausência dos nanocompósitos. Calculando aproximadamente essa ausência de absorbância, vemos que subtraindo $40 \%$ do espectro de NFX praticamente se reproduz o espectro dos AuNCs, exceto por uma leve ondulação. Isso indica que em presença de AuNCs apenas $40 \%$ de NFX aparece no espectro de extinção, ou seja, não estamos vendo toda a contribuição da NFX, devido possivelmente a um efeito sombra dos AuNCs.

Os espectros de fluorescência da NFX variando com o tempo depois da adição de NFX aos AuNCs tratados com citrato (AuNC-citr) foram obtidos imediatamente após cada espectro de absorção/extinção e os resultados são apresentados na Fig. 5.22 .
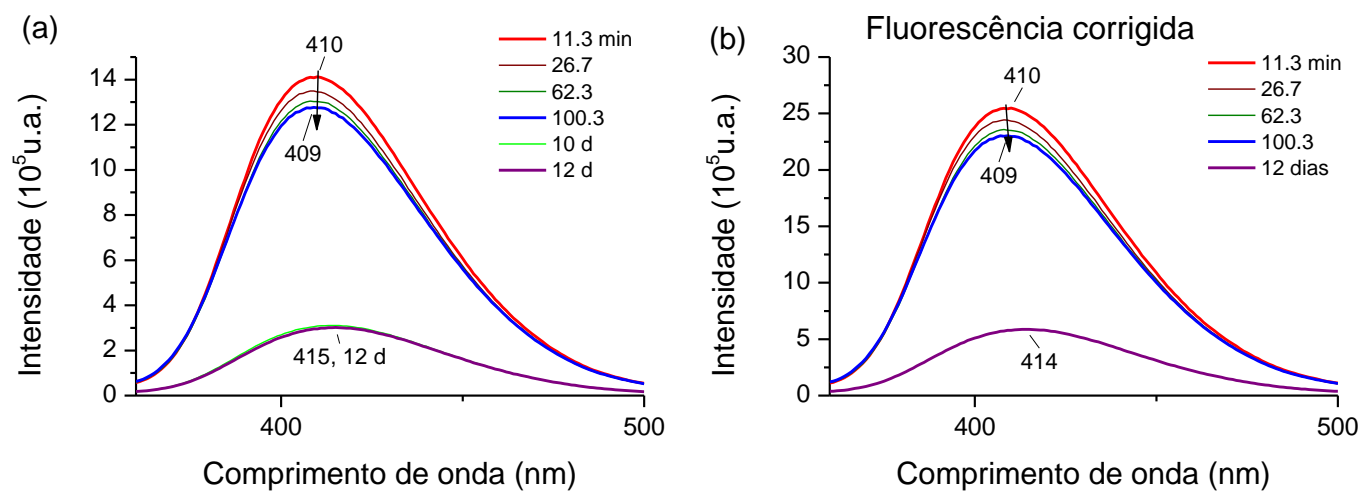

Figura 5.22. (a) Espectros de fluorescência da NFX $40 \mu \mathrm{M}$ em AuNCs-citr em diferentes instantes de tempo. (b) Espectros (a) corrigidos. Excitação em $330 \mathrm{~nm}$.

Podemos observar da Fig. 5.22 (a) uma lenta supressão da intensidade de fluorescência, com deslocamento batocrômico de $5 \mathrm{~nm}$ do pico em $409 \mathrm{~nm}$ depois de 12 dias, com significativa redução da fluorescência. Essa supressão poderia indicar que novos complexos de NFX com AuNCs-citr estariam se formando, suprimindo a fluorescência da NFX, mas também deveríamos considerar uma possível degradação da NFX depois de 12 dias. A NFX se mantém na sua forma zwitteriônica, pois o pico característico da fluorescência nesta forma está em torno de 409 nm quando em água. 
Fazendo as correções dos efeitos de filtro interno na excitação e na emissão (Fig. 5.22 (b)), com $\ell_{\text {exc }}=0,4 \mathrm{~cm}$ e $\ell_{\mathrm{em}}=1,0 \mathrm{~cm}$, podemos ver o mesmo comportamento da fluorescência não corrigida, portanto existe supressão da fluorescência ao passar o tempo.

Todos estes resultados sugerem que a interação de FQs com AuNCs em água provocam aglomeração, mas a interação de NFX com AuNCs previamente tratados com citrato modificam sua superfície sem provocar agregação dos mesmos. As mudanças na banda plasmônica dos AuNCs-citr são também consideráveis, em menor proporção do que apenas em água; e as bandas de absorção da NFX ligada aos AuNCs-citr apresentam hipocromismo. As mudanças na fluorescência não são tão notórias dentro do intervalo de uma hora, mas ao passar um maior tempo se pode ver uma supressão significativa. Dita supressão foi observada em menor intensidade por Grace e Pandian, 2007 quando aumentada a concentração de AuNPs. Esse resultado de supressão indica que a NFX começa a se ligar à superfície dos AuNCs lentamente, diminuindo a quantidade de espécies zwiteriônicas livres em água.

\section{Efeito de tióis em NFX/AuNCs-citr}

Grupos tióis ligam-se covalentemente às nanopartículas de ouro. Devido a que glutationa (Fig. 4.2) contém grupo tiol (-SH), utilizamos esse composto para estudamos se este é capaz de deslocar as moléculas de NFX ligadas às AuNCs. Utilizando as amostras anteriores contendo NFX com AuNCs-citr, depois de 12 dias adicionamos GSH 6,7 $\mu \mathrm{M}$ e depois GSH $40 \mu \mathrm{M}$.

Na Fig. 5.23 (a) podemos notar pouca diminuição da banda plasmônica dos AuNCs-citr para as concentrações de GSH 6,7, 13 e $40 \mu \mathrm{M}$. Já na região correspondente à NFX, vemos uma considerável diminuição da absorbância. A GSH, para reagir com $\mathrm{Au}$, pode ter deslocado algumas moléculas de NFX da superfície dos AuNCs, mas também não devemos descartar a possibilidade de GSH ter deslocado citratos, ou ainda ter se ligado a regiões descobertas da superfície dos AuNCs. 

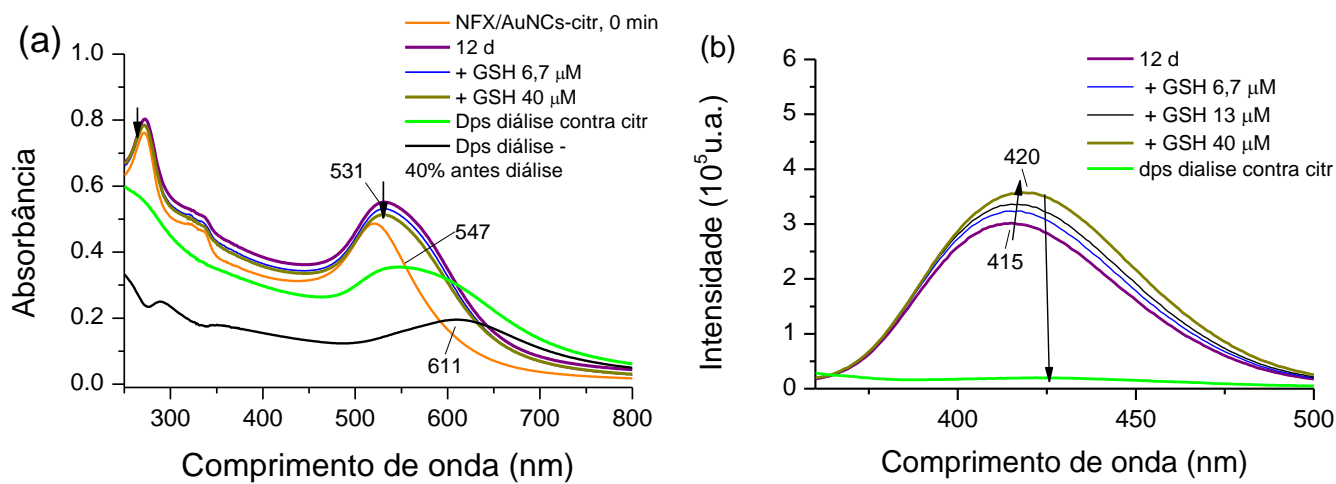

Figura 5.23. NFX/AuNCs-citr depois de adicionar GSH 6,7, 13 e $40 \mu \mathrm{M}$ e depois de dialisar contra citrato. (a) Absorção/extinção. Espectro preto é o espectro depois da diálise menos $40 \%$ antes da diálise. (b) Efeito da adição de GSH na fluorescência.

Para verificar se a GSH desloca moléculas de NFX da superfície dos AuNCs, devemos também analisar a fluorescência depois da adição de GSH (Fig. 5.23 (b)). Observa-se um aumento de aproximadamente $20 \%$ na intensidade de fluorescência e um deslocamento do pico de 415 para $420 \mathrm{~nm}$. Isso demonstra que a GSH foi capaz de liberar moléculas de NFX da superfície de AuNCs aumentando a fluorescência.

Para verificar a reversibilidade das ligações dos AuNCs com NFX, a amostra foi submetida a diálise contra citrato $0,1 \mathrm{mM}$ (por 2 dias, com troca da solução de diálise). Depois da diálise obtivemos uma diminuição e alargamento da banda plasmônica (Fig. 5.23 (a)), com deslocamento para $547 \mathrm{~nm}$. Para ver o efeito da NFX no espectro dos AuNCs, subtraiu-se 40\% da absorbância da NFX. O espectro resultante (linha preta) mostra uma banda com pico em $611 \mathrm{~nm}$. Na região correspondente à NFX, podemos notar claramente que toda a contribuição da NFX foi anulada mediante diálise, sugerindo que toda a NFX se separou dos AuNCs.

Analisando os espectros de fluorescência (Fig. 5.23 (b)) vemos que, depois da diálise, a fluorescência caiu abruptamente. Como já foi visto nos gráficos de absorbância, a presença da NFX foi praticamente nula, e também por fluorescência podemos ver que ficou pouquíssima quantidade de NFX na solução, indicando liberação completa de NFX dos nanocompósitos.

\section{Interação com a Levofloxacina}

Nesta experiência, com o fim de comparar os efeitos produzidos nos AuNCs em citrato com NFX, repetimos alguns procedimentos nas mesmas condições, 
substituindo NFX por LFX. Foi adicionado citrato de sódio 0,1 mM aos AuNCs sem NFX e obtivemos os espectros de extinção antes e após a adição em intervalos de 5 minutos, os quais não foram colocados aqui pois mostraram variação nula na forma dos espectros, indicando estabilidade em citrato.

Na Fig. 5.24 se apresenta o espectro dos AuNCs-citr e LFX $40 \mu \mathrm{M}$ em água, com picos característicos em pH 7,4 de 256, 288 e $331 \mathrm{~nm}$. Ao adicionar LFX $40 \mu \mathrm{M}$ a AuNCs-citr obtivemos a evolução temporal dos espectros. Até 100 min depois da adição de LFX o espectro resultante é praticamente a superposição do espectro de LFX com o dos AuNCs-citr. Após 3 dias, observa-se na região da banda plasmônica um deslocamento de 518 para $524 \mathrm{~nm}$, sem mudança observável de cor nem formação de precipitados até 18 dias. O deslocamento do pico e o ligeiro alargamento da banda plasmônica sugerem pouca modificação na superfície e pouca aglomeração dos AuNCs-citr, causada pela fraca interação do antibiótico LFX com a superfície dos AuNCs-citr.

Comparando a superposição dos espectros de LFX e AuNCs-citr (curva ciano) com o espectro dos AuNCs-citr após adição de LFX, observa-se uma pequena queda na absorbância na região da LFX.

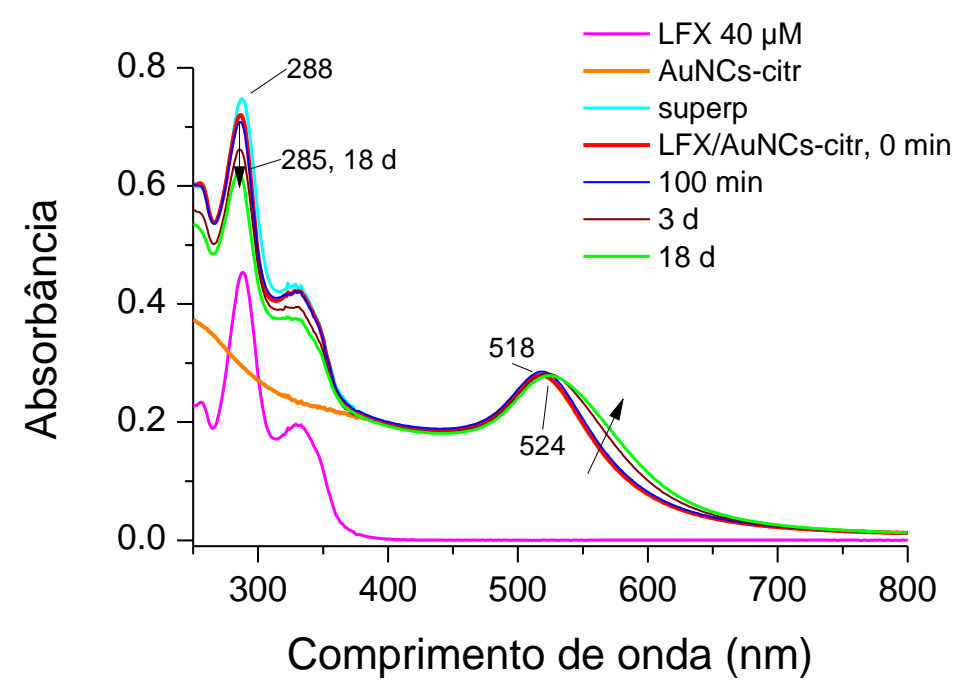

Figura 5.24. Espectros de absorção/extinção de LFX $40 \mu \mathrm{M}$ (magenta) e de AuNCs tratados com $0,1 \mathrm{mM}$ de citrato de sódio (laranja); evolução temporal dos espectros depois de adicionar LFX $40 \mu \mathrm{M}$.

Na Fig. 5.25 fazemos uma análise das modificações espectrais subtraindo o espectro de AuNCs-citr dos espectros de AuNCs-citr após adição de LFX, nos diferentes tempos. Na região da banda plasmônica observa-se o crescimento da banda e deslocamento batocrômico depois de vários dias. 


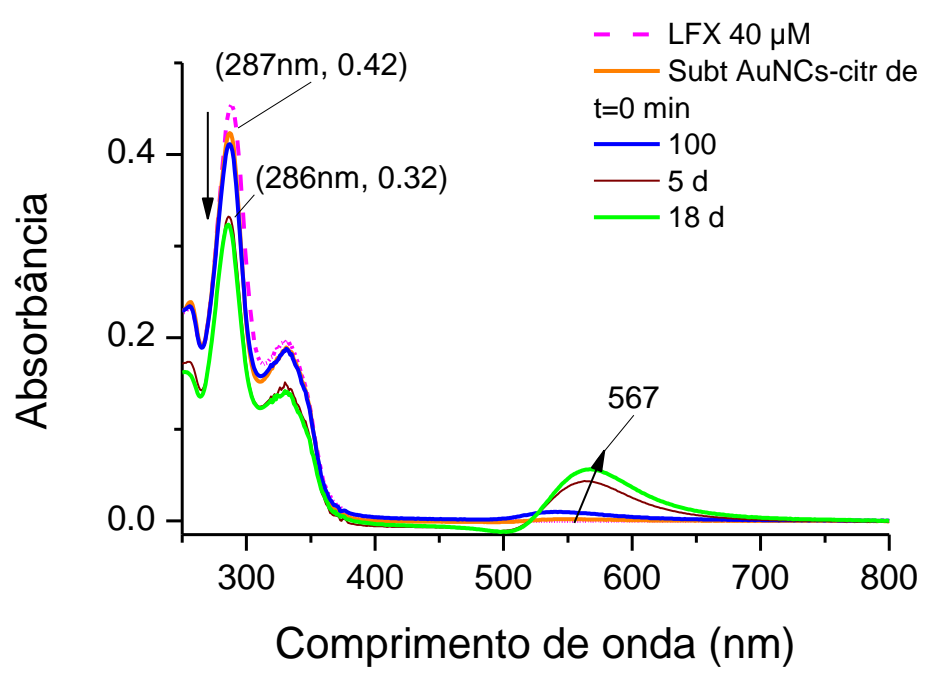

Figura 5.25. Análise dos espectros de extinção mediante subtração espectral: espectros em diferentes tempos após adição de LFX subtraindo o espectro de AuNCs.

Também da Fig. 5.25 obtivemos uma redução de 10\% da absorbância na região da LFX em relação ao esperado para uma concentração de $40 \mu \mathrm{M}$, nos 100 primeiros minutos após adição aos AuNCs. Após 5 dias, essa absorbância da LFX diminui para 28\%, aproximadamente. Assim como ocorreu com a NFX, não estamos vendo toda a contribuição da LFX, provavelmente por causa da ligação à superfície dos AuNCs-citr.

Com isto, podemos dizer desses espectros que a absorbância detecta interação da LFX com os nanocompósitos em citrato. No entanto, comparando Fig. 5.25 com Fig. 5.21 (a), esta interação foi bem menor do que no caso com NFX.

Os espectros de fluorescência da LFX, variam com o tempo decorrido após adicionar LFX aos AuNCs-citr. Esses espectros foram obtidos imediatamente após cada medida de absorbância e os resultados são apresentados na Fig. 5.26. 

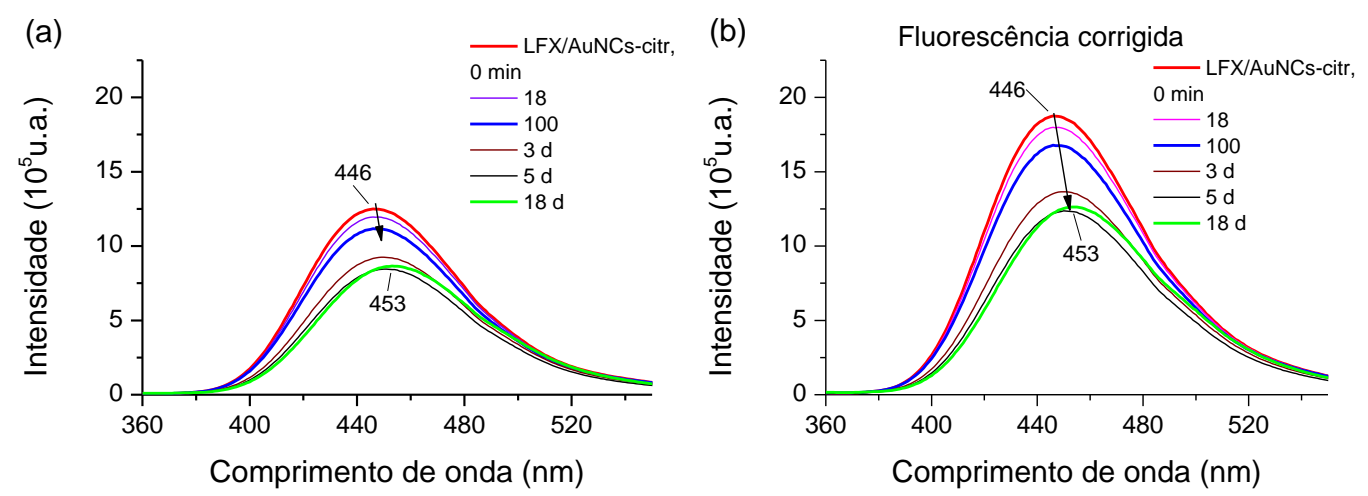

Figura 5.26. (a) Espectros de fluorescência da LFX $40 \mu \mathrm{M}$ em AuNCs-citr para cada intervalo de tempo. Excitação em $335 \mathrm{~nm}$. (b) Espectros de (a) corrigidos por efeito filtro, de acordo com a Eq. 4.5, com $\ell_{e m}=0,4 \mathrm{~cm} \mathrm{e} \ell_{e x c}=1,0 \mathrm{~cm}$.

Podemos observar aqui uma lenta supressão da intensidade de fluorescência, com deslocamento batocrômico de $7 \mathrm{~nm}$ do pico em $446 \mathrm{~nm}$ depois de 18 dias. Considerando efeitos de filtro interno na excitação e na emissão (Fig. 5.26 (b)), podemos ver o mesmo comportamento. Observou-se menor redução da fluorescência em comparação ao caso da NFX depois de vários dias. A redução pode indicar que ligações de LFX aos AuNCs-citr estariam suprimindo a fluorescência da LFX por interação eletrônica, como também poderia existir uma pequena degradação da LFX. A LFX se mantém na sua forma catiônica, pois o pico característico da fluorescência nesta forma está em torno de $449 \mathrm{~nm}$.

Podemos concluir que nanocompósitos de ouro feitos via ablação a laser, mantidos em água ultrapura, interagem com as FQs. Esta interação provoca rápida agregação dos AuNCs. Já com os AuNCs estabilizados com 0,1 mM de citrato vemos que a mudança na banda plasmônica foi muito menor, muito mais demorada, e ocorreu sem precipitação de partículas.

Ao comparar a interação dos AuNCs-citr com LFX e NFX, vemos que há maior interação com NFX. Os espectros de absorção/extinção indicam maior quantidade de moléculas de NFX se ligando aos AuNCs devido ao efeito sombra presente na região das FQs.

Mediante fluorescência conseguimos verificar a interação de AuNCs-citr com NFX, que provocou supressão. O pico da fluorescência para cada fluorquinolona não mudou significativamente, indicando que a fluorquinolona não muda o seu estado inicial de protonação. 
Por outro lado, a glutationa, que possui um grupo tiol, liga-se fortemente ao ouro dos AuNCs, conseguindo deslocar alguma quantidade de NFX ligada à superfície dos AuNCs, devido a que a fluorescência aumentou quando adicionamos GSH.

Foi também possível verificar a reversibilidade das ligações dos AuNCs-citr com NFX mediante diálise contra citrato. Os resultados de espectroscopia UV-Vis mostraram uma diminuição notável do pico da banda plasmônica e alargamento da banda. Na região correspondente à NFX quase toda a contribuição da NFX foi anulada mediante diálise. Os espectros de fluorescência mostraram uma abrupta queda da fluorescência, confirmando o visto nos espectros de extinção, que a contribuição de NFX na solução após diálise foi quase nula, indicando separação completa do fármaco dos nanocompósitos.

Portanto, nesta seção podemos ver que as FQs CFX, NFX e LFX interagem bem com a superfície dos AuNCs, provocando agregação e mudanças na banda plasmônica. Tais mudanças, como o deslocamento batocrômico e hipocromismo, sugerem mudança no índice de refração na superfície dos AuNCs, por associação com o fármaco e/ou formação de aglomerados como resultado da interação da fluorquinolona com a superfície dos nanocompósitos. Esta interação é diferente da observada com nanopartículas sintetizadas por via química [Grace e Pandian, 2007], sem a presença de pontos isobésticos.

\section{4 .3}

\section{Interação de NFX com nanopartículas de ouro sintetizadas por via química em CTAB}

Diversos estudos mostram que as FQs interagem com as nanopartículas de ouro sintetizadas por via química, estabilizadas em citrato. Grace e Pandian, 2007 mostraram mediante o uso de diversas técnicas espectroscópicas a interação do antibiótico NFX com a superfície das nanopartículas.

Com a finalidade de continuar o estudo das interações de FQs com nanopartículas de ouro, nesta seção analisamos a interação da NFX com nanopartículas sintetizadas por via química no surfactante catiônico CTAB (AuNPCTAB), para compararmos com o estudo feito com as nanopartículas via ablação a laser. 
Particularmente, nessa seção estudamos a interação do antibiótico fluorescente NFX com as AuNP-CTAB em água, tentando comparar a interação destas nanopartículas com os AuNCs. No entanto, o recobrimento com surfactantes diferentes tornou a comparação imprecisa.

Para as nossas experiências, adicionamos NFX às amostras contendo AuNPCTAB em água (sem tamponar, pH inicial 6.2), e estudamos os efeitos de interação na absorbância tanto de NFX quanto na banda plasmônica das nanopartículas, bem como na fluorescência estacionária de NFX, em diferentes intervalos de tempo.

A Fig. 5.27 mostra o espectro de extinção das nanopartículas (laranja) com pico em $526 \mathrm{~nm}$ e o espectro de NFX em água (pH 6,5). O espectro de absorção/extinção das AuNP-CTAB, ao adicionar NFX $40 \mu \mathrm{M}$ é também apresentado na Fig. 5.27 (vermelho). Ele é idêntico à superposição dos espectros de AuNP-CTAB e NFX, e manteve-se estável por no mínimo 10 dias.

Ao adicionarmos NFX às AuNP-CTAB não houve mudança de cor. Na Fig. 5.27 se observa, na região da banda plasmônica, um pequeno deslocamento batocrômico de $2 \mathrm{~nm}$. Esse pequeno deslocamento do pico da banda plasmônica sugere pouca modificação na superfície das AuNPs, devido a uma muito fraca interação do antibiótico NFX com a superfície das AuNP-CTAB. Depois de 10 dias não houve precipitação, e o pico se manteve em $528 \mathrm{~nm}$, sem mudança de cor nem formação de precipitados. Isto sugere que a NFX em estado catiônico não interage com nanopartículas em CTAB.

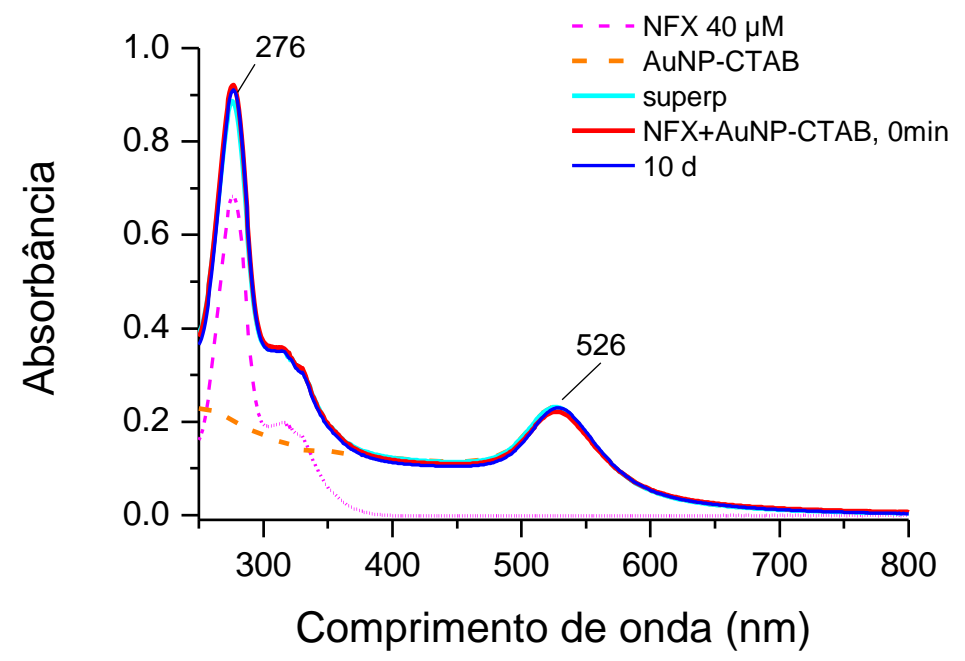

Figura 5.27. Espectros de absorção/extinção de NFX em água (magenta), AuNP-CTAB antes (laranja) e depois (vermelho) de tratar com NFX $40 \mu \mathrm{M}$. O espectro manteve-se inalterado por 10 dias (azul). 
Os espectros de fluorescência da NFX, depois da adição do fármaco às AuNPCTAB, foram obtidos imediatamente após cada espectro de absorção e os resultados são apresentados na Fig. 5.28. Nota-se uma diminuição inicial da fluorescência e depois de 10 dias houve um leve incremento da fluorescência. $\mathrm{O}$ pico em torno de $439 \mathrm{~nm}$ indica que as moléculas de NFX encontram-se com o grupo amina e ácido carboxílico protonados, portanto no estado catiônico, o qual está de acordo em pH ácido.

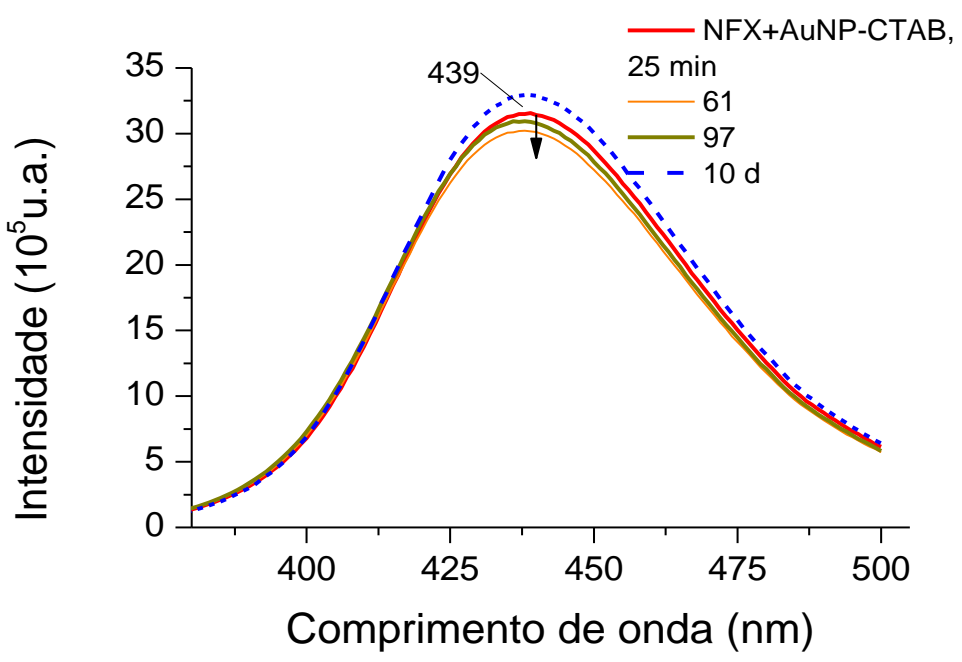

Figura 5.28. Espectros de fluorescência da NFX $40 \mu \mathrm{M}$ em AuNP-CTAB, em diferentes intervalos de tempo após adição. Espectros corrigidos de acordo com a Eq. 4.5, lexc $=0,4 \mathrm{~cm}$ e $\ell_{\mathrm{em}}=1,0 \mathrm{~cm}$. Exc. $330 \mathrm{~nm}$.

Também não podemos descartar que essas pequenas modificações da fluorescência sejam devidas a possíveis flutuações de intensidade de fluorescência. Todos estes resultados sugerem que a interação de NFX em estado catiônico com as AuNP-CTAB não é significativa.

\section{Efeito de tamponamento em pH 7,4 nos espectros de absorção/extinção e fluorescência}

Para estudar as modificações em pH fisiológico, depois de 10 dias adicionamos tampão fosfato $1 \mathrm{mM} \mathrm{pH} \mathrm{7,4} \mathrm{às} \mathrm{amostras} \mathrm{anteriores} \mathrm{de} \mathrm{AuNP-CTAB}$ com NFX. Com isso foram obtidos os espectros de absorção/extinção das AuNPCTAB com NFX em diferentes instantes de tempo (Fig. 5.29 (a)). As amostras apresentaram uma coloração azulada com o passar de minutos. 

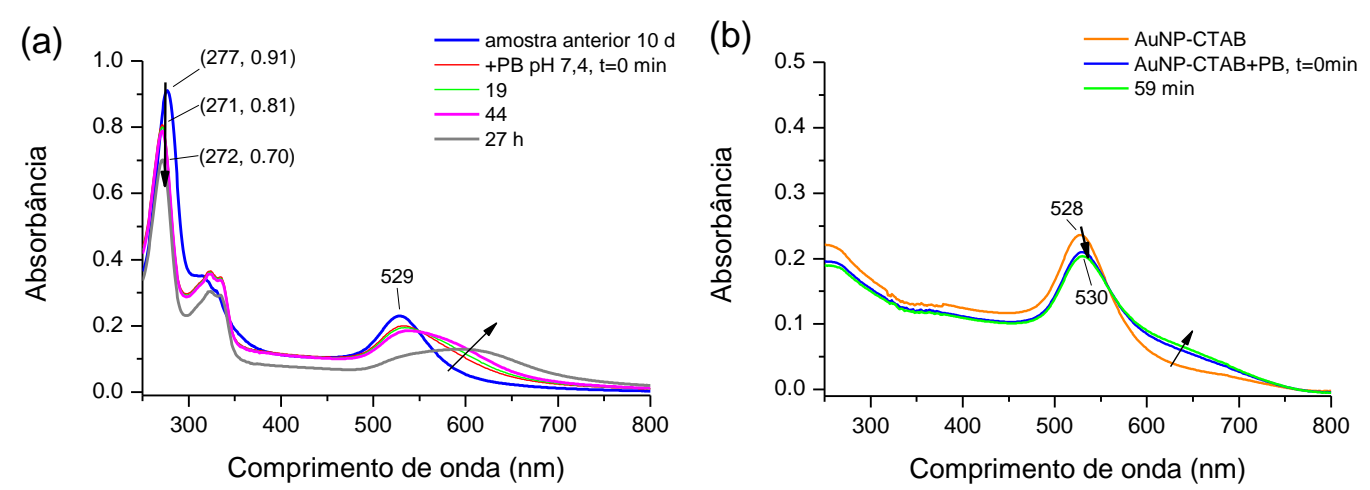

Figura 5.29. Espectros de absorção/extinção de (a) AuNP-CTAB com NFX antes e após adicionar $\mathrm{PO}_{4} 1 \mathrm{mM}$. Amostras medidas em diferentes intervalos de tempo. (b) Controle: AuNP-CTAB antes e após adicionar tampão $\mathrm{PO}_{4} 1 \mathrm{mM}, \mathrm{pH} 7,4$.

Podemos ver que, quando adicionamos tampão fosfato $\mathrm{pH} 7,4$ às amostras anteriores, há uma mudança no espectro de absorção da NFX, assim como um deslocamento hipsocrômico, o qual é característica de uma transição da forma catiônica para zwitteriônica. Na banda plasmônica das AuNP-CTAB observa-se um deslocamento batocrômico no pico de $528 \mathrm{~nm}$ e considerável efeito hipocrômico, chegando o pico a $597 \mathrm{~nm}$ no dia seguinte. Este deslocamento e o alargamento da banda plasmônica indicam mudanças na superfície das AuNP-CTAB, indicando interação com a NFX ao mudar o pH.

A mudança na carga elétrica das moléculas de NFX, de catiônica para zwitteriônica teve como consequência o aumento da interação do antibiótico com as nanopartículas, recobertas com o surfactante catiônico CTAB. A diminuição da absorbância da NFX com o passar do tempo sugere a incorporação de NFX à superfície das AuNP-CTAB.

Como controle da interação da NFX com as nanopartículas, foram obtidos os espectros de absorção das AuNP-CTAB sem NFX em PB 1 mM, pH 7,4, em intervalos de 5 em 5 minutos (Fig. 5.29 (b)). O pico das AuNP-CTAB se desloca $2 \mathrm{~nm}$, mantendo-se em $530 \mathrm{~nm}$ nos diferentes tempos. Também observamos um efeito hipocrômico e aparecimento de uma banda plasmônica larga, sugerindo aglomeração. Podemos dizer que o tampão fosfato provoca alguma mudança na banda plasmônica das AuNPs, mas em presença de NFX as mudanças foram notavelmente mais significativas.

Os espectros de fluorescência (Fig. 5.30) com o tempo, depois da adição de tampão fosfato $1 \mathrm{mM}, \mathrm{pH}$ 7,4, foram obtidos imediatamente após cada espectro de absorção e a influência da mudança de pH na interação de NFX com as AuNP- 
CTAB foi estudada. A Fig. 5.30 mostra os espectros de fluorescência da NFX sem correção (a) e com correção segundo Eq. 4.5 (b). Observa-se que o espectro em água $(\mathrm{pH}$ 6,5) é bem diferente do da solução tamponada em pH 7,4. Ao adicionar AuNPs, ainda sem tamponar, vemos pouca variação, após correção do efeito filtro (Fig. 5.30 (b)). Após adição de tampão, houve um deslocamento do pico de $439 \mathrm{~nm}$ para 406 nm, o qual indica a transição da NFX, de espécie catiônica para sua forma zwitteriônica. Essa transição também foi percebida nos espectros de absorção (região das bandas de NFX, 250 a $350 \mathrm{~nm}$ ). Observa-se um pequeno incremento de fluorescência com o passar do tempo, que pode estar relacionado com o aumento do campo elétrico da radiação na superfície da nanopartícula.
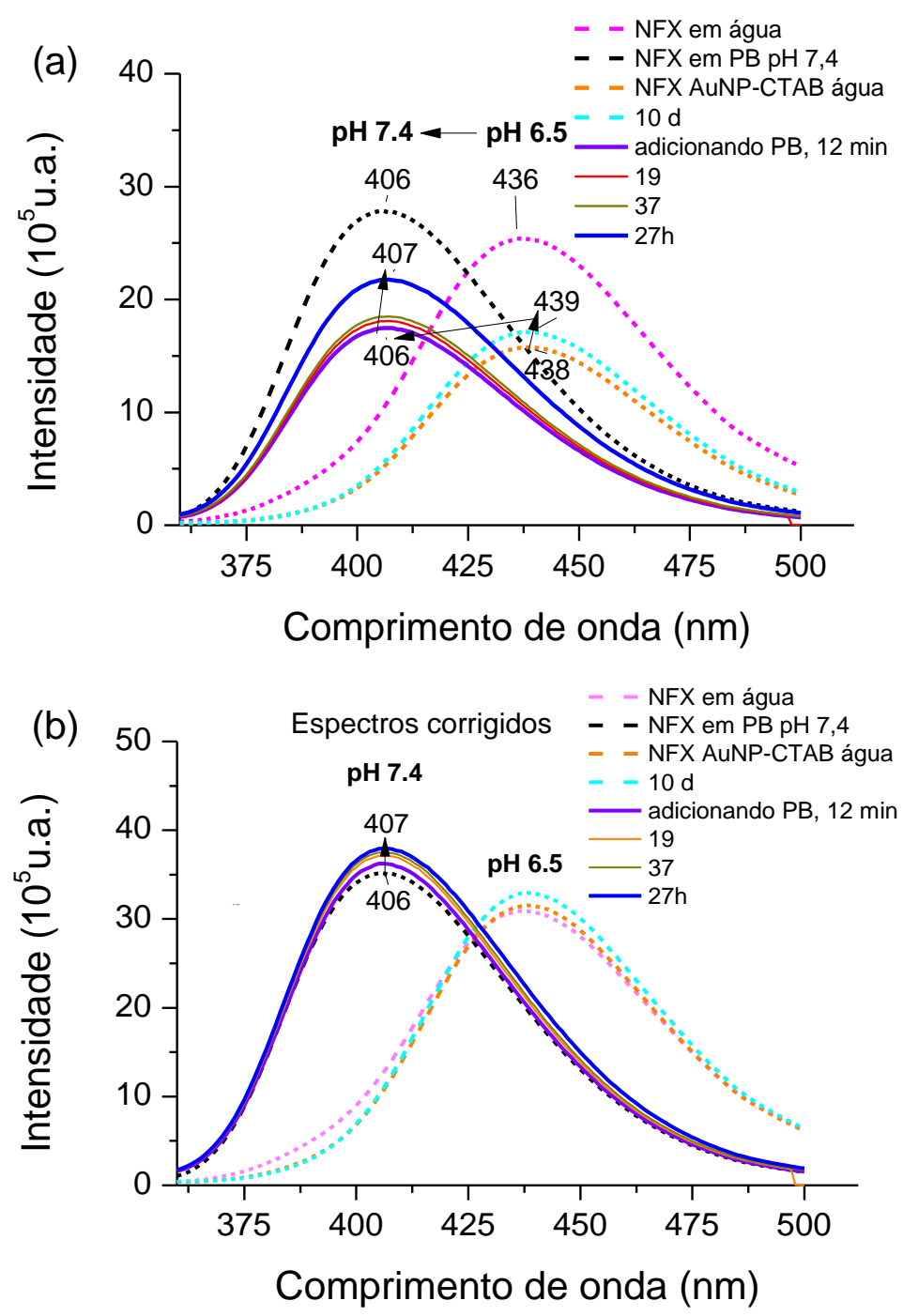

Figura 5.30. (a) Espectros de fluorescência da NFX $40 \mu \mathrm{M}$ em AuNP-CTAB antes e depois de tamponar a solução com PB, para cada instante de tempo. Excitação em $330 \mathrm{~nm}$. (b) Espectros de (a) corrigidos de acordo com Eq. 4.5. 
Os resultados desta seção mostram que a NFX em estado catiônico não interage significativamente com as AuNP-CTAB, o que pode ser explicado pela repulsão eletrostática entre NFX e a superfície das nanopartículas, também positivamente carregada devido ao grupo polar catiônico das moléculas de CTAB. Mas, quando alterado o $\mathrm{pH}$ do meio, para $\mathrm{pH}$ fisiológico 7,4, a NFX torna-se zwitteriônica e passa a interagir com as AuNP-CTAB, provocando mudanças na superfície e agregação das mesmas. As mudanças na banda plasmônica são consideráveis e as bandas de absorção da NFX apresentam notório hipocromismo. O rendimento quântico de fluorescência apresenta um leve incremento, provavelmente por transferência de energia devido à ressonância de plasmon de superfície.

\section{4 .4}

\section{Interação de NFX com AuNCs sintetizados em SDS}

A fim de continuar o estudo da interação de NFX com os AuNCs, desta vez estudamos esta interação com nanocompósitos produzidos em presença do surfactante aniônico SDS (AuNC-SDS). Esse surfactante, que em solução aquosa apresenta cabeça polar negativa, se mostrou promissor por associar-se fortemente com NFX em comparação com surfactantes catiônicos e neutros [Muniz et al., 2014]. Estudos mostram que os AuNCs são estáveis em água e instáveis em tampões isotônicos [Del Rosso et al., 2018], mas alguns surfactantes, como é o caso com SDS [Fong et al., 2010], os tornam estáveis em tampões isotônicos (força iônica 0,15 M). Então, aproveitando essa afinidade do SDS com NFX e a estabilidade de AuNCs em soluções do surfactante, estudamos a interação de NFX com AuNC-SDS e, para comparação, estudamos a interação de NFX com AuNCs adicionando SDS depois da síntese (AuNC+SDS). Usamos diferentes concentrações de NFX e observamos a estabilidade dos espectros UV-Vis e de fluorescência com o passar do tempo.

Nesta seção os AuNCs foram preparados em surfactante aniônico SDS 10 mM, pH 6,25 medido depois da preparação, com concentração da mesma ordem da utilizada por Fong et. al., 2010. Esta concentração foi escolhida por encontrarse acima da CMC [Shah et al., 2001], pois as micelas de SDS interagem bem com a NFX, portanto se espera ver uma interação adicional entre AuNC-SDS e NFX. 
Para as nossas experiências adicionamos NFX em concentrações de 10, 20 e $40 \mu \mathrm{M}$ aos AuNC-SDS, e obtivemos a evolução temporal dos espectros para cada concentração de NFX. A Fig. 5.31 mostra a absorbância dos AuNC-SDS (vermelho), com a banda plasmônica em 518 nm, e de NFX em SDS (preto), com picos característicos em 330, 318 e $280 \mathrm{~nm}$, assim como os espectros de NFX (para diferentes concentrações) ao adicionar aos AuNC-SDS. Os espectros temporais, para cada concentração de NFX, não mostraram mudanças na banda plasmônica, apenas houve uma pequena diminuição da banda da NFX no pico de $278 \mathrm{~nm}$, a qual poderia estar relacionada com um pequeno efeito sombra. Os espectros foram praticamente iguais à soma dos espectros dos componentes (AuNC-SDS e NFX) para todas as concentrações de NFX, pelo menos até 4 horas.

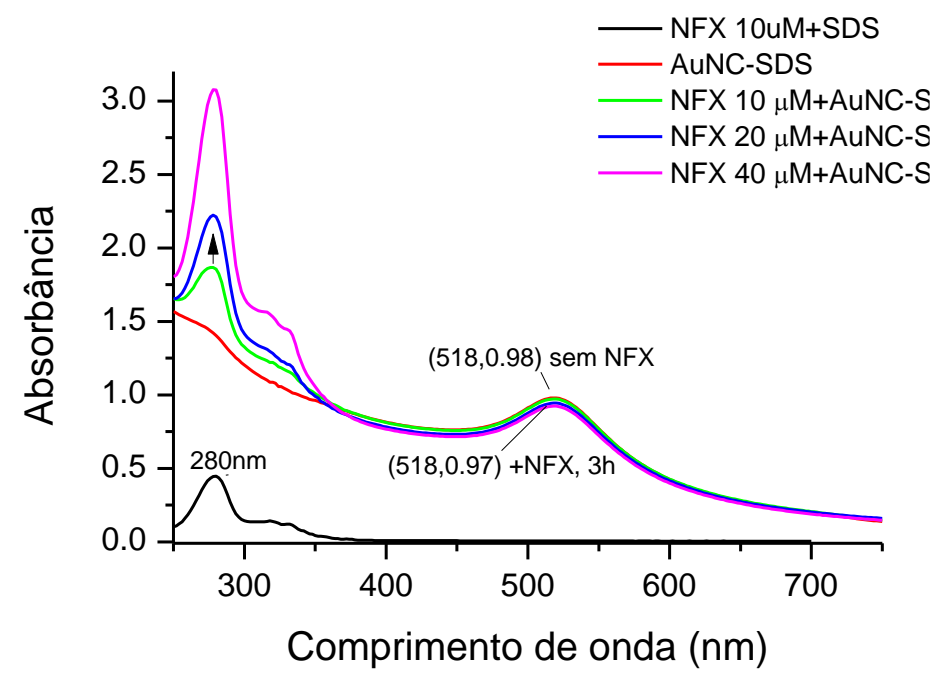

Figura 5.31. Espectros de absorção/extinção de AuNCs sintetizados em SDS 10 mM (AuNC-SDS) antes (vermelho) e após adicionar NFX $10 \mu \mathrm{M}$ (verde), $20 \mu \mathrm{M}$ (azul) e $40 \mu \mathrm{M}$ (magenta). O espectro de NFX $10 \mu \mathrm{M}$ em SDS (preto) é também mostrado.

Não há mudanças espectrais com o passar do tempo. Os resultados indicam que os espectros de absorção/extinção não detectam interação de NFX com AuNCSDS.

Os espectros de fluorescência da NFX foram obtidos imediatamente após registrar cada espectro UV-Vis e foi observada sua variação com o tempo. Os resultados com NFX $10 \mu \mathrm{M}$ são apresentados na Fig. 5.32, antes e após a correção de efeito filtro. Como a fluorescência da NFX depende fortemente do $\mathrm{pH}$ do meio, os valores de $\mathrm{pH}$ foram medidos e são mostrados nos gráficos. 
Os espectros da Fig. 5.32 (b), comparados com os de (a), mostram que a correção de filtro interno é importante para análise dos resultados. O incremento da fluorescência da NFX 3 horas após adição aos AuNC-SDS foi obtido por integração dos espectros de fluorescência (áreas das curvas correspondentes). Esse incremento foi de $32,8 \%$ da área inicial.
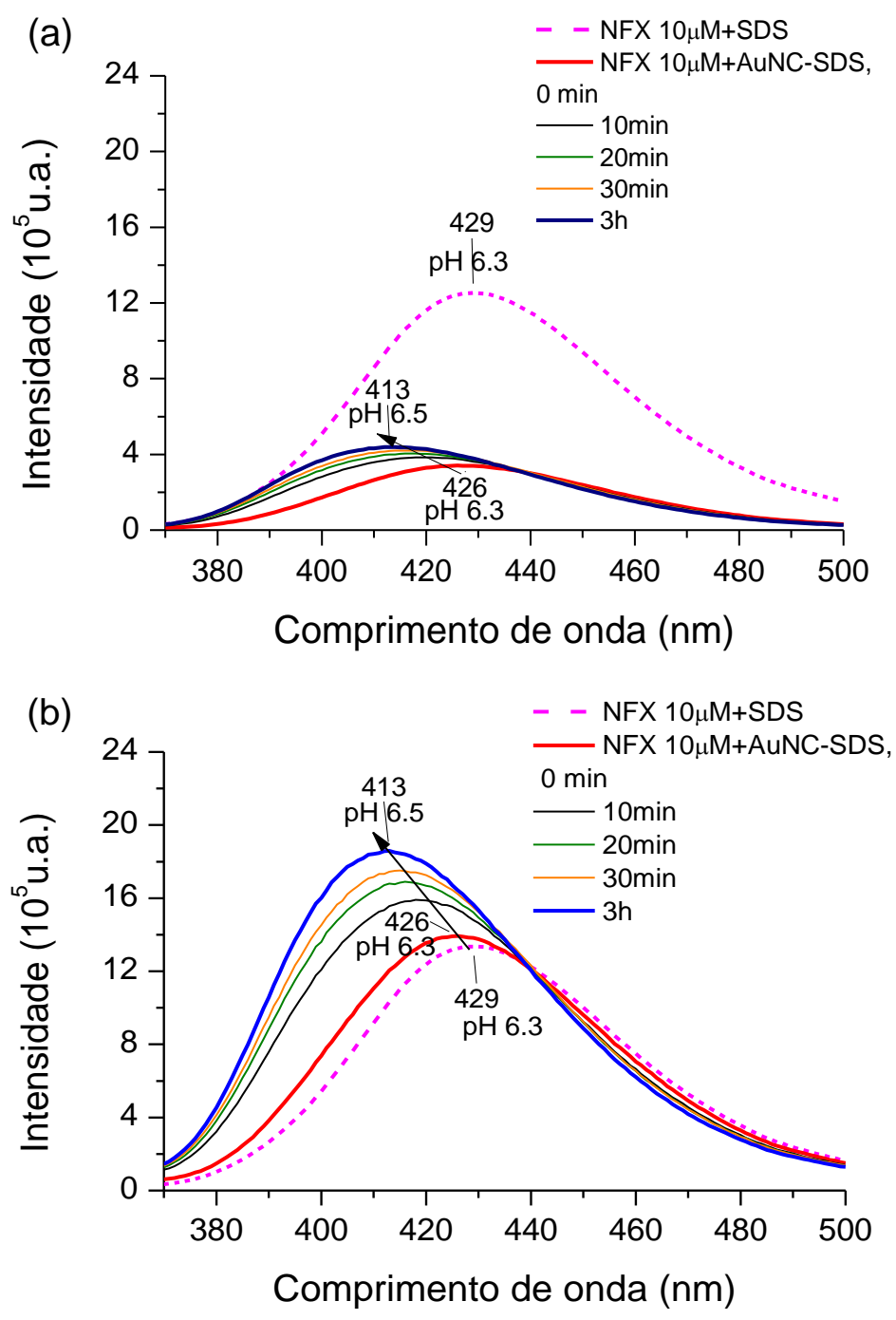

Figura 5.32. Espectros de fluorescência da NFX $10 \mu \mathrm{M}$ em AuNC-SDS, para cada instante de tempo. (a) sem correção; (b) corrigidos conforme Eq. 4.5. Exc. $330 \mathrm{~nm}$.

A Fig. 5.33 mostra os espectros de fluorescência já corrigidos para as concentrações de NFX 20 e $40 \mu \mathrm{M}$.

Vemos que todos os espectros de fluorescência da NFX em presença dos AuNC-SDS (Fig. 5.32 (b) e 5.33 (a) e (b)) começam com um rendimento quântico menor $(\mathrm{t}=0 \mathrm{~min})$, mas com o passar do tempo apresenta leve aumento $\mathrm{e}$ deslocamento hipsocrômico (para o azul). O deslocamento depois de $4 \mathrm{~h}$ foi de $13 \mathrm{~nm}, 6 \mathrm{~nm}$ e $5 \mathrm{~nm}$, para NFX 10, 20 e $40 \mu \mathrm{M}$, respectivamente. O aumento da 
fluorescência e o deslocamento hipsocrômico acontecem devido à interação do fármaco com a superfície dos AuNC-SDS.
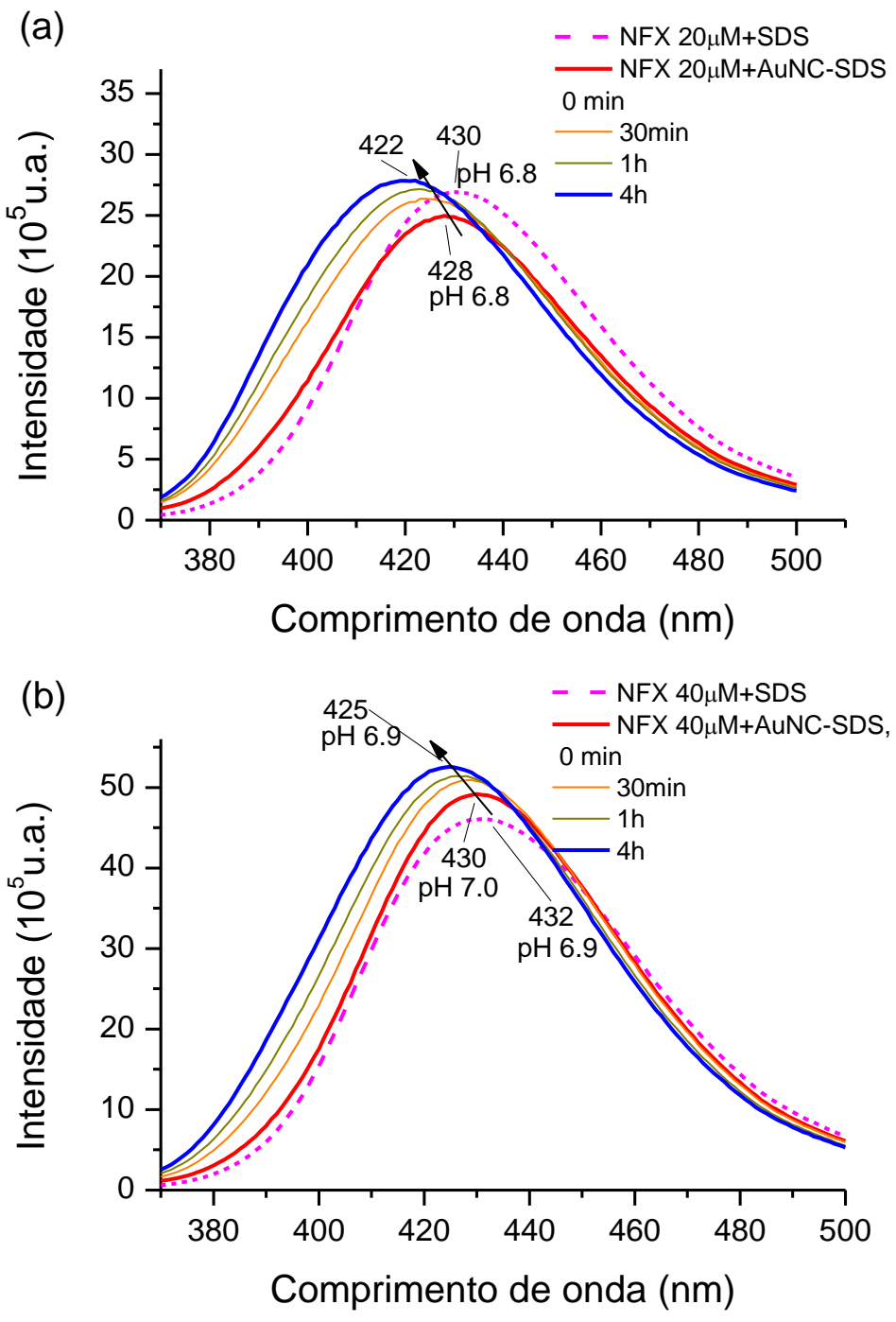

Figura 5.33. Espectros de fluorescência da NFX $20 \mu \mathrm{M}$ (a) e $40 \mu \mathrm{M}$ (b) em AuNC-SDS para cada instante de tempo, corrigidos conforme Eq. 4.5. Exc. $330 \mathrm{~nm}$.

A NFX em micelas de SDS apresenta pico de fluorescência em $432 \mathrm{~nm}$. É importante lembrar que cargas elétricas associadas à superfície das nanopartículas mudam o pH local. $\mathrm{O}$ pH local em superfícies negativamente carregadas é menor do que o pH no bulk.

Muniz et al., 2014; estudando a interação de NFX com SDS, relataram um incremento do rendimento quântico de fluorescência e um deslocamento para o vermelho do pico de fluorescência quando NFX se liga às micelas de SDS. O deslocamento para o azul do pico de fluorescência da NFX pode sugerir aumento no $\mathrm{pH}$ próximo à superfície dos AuNC-SDS, em relação ao $\mathrm{pH}$ na superfície de micelas de SDS. A NFX pode estar passando do ambiente puramente micelar para 
a superfície dos AuNCs. O incremento do rendimento quântico poderia ser explicado pela proximidade da NFX à superfície dos AuNC-SDS. A luz incidente na amostra modifica o campo elétrico das nanopartículas (ressonância de plasmon de superfície) que por transferência de energia excitaria com maior intensidade as moléculas de NFX.

Estes resultados mostram que a interação de NFX com AuNCs sintetizados em presença de SDS não provoca agregação das mesmas. As mudanças nos espectros de absorção/extinção são desprezíveis. As mudanças na fluorescência são maiores nas concentrações menores de NFX.

Para descartar possíveis efeitos micelares sugere-se trabalhar em concentrações de SDS abaixo da CMC, ao invés de SDS 10 mM (Fong et. al., 2010, sintetizaram AuNC-SDS em concentrações da ordem de SDS 0,1 mM). Mesmo em força iônica mais alta, SDS na presença de NFX tem CMC em torno de 1,5 mM [Muniz et al., 2014]. Então, se poderia trabalhar em concentrações abaixo da CMC, na faixa de 0,5-2 mM, para descartar possíveis efeitos micelares adicionais.

Interação de NFX com AuNCs adicionando-se SDS após ablação

Para comparar os efeitos de SDS adicionados antes e depois da ablação, adicionou-se SDS $10 \mathrm{mM}$ a AuNCs sintetizados por ablação a laser em água. Experimentos análogos aos das Figs. 5.31a 5.33 foram realizados nas mesmas condições. Os resultados dos espectros de absorção/extinção dos AuNC+SDS ao adicionar NFX foram muito semelhantes aos resultados dos AuNC-SDS, com modificações desprezíveis (resultados não mostrados por serem muito semelhantes aos da Fig. 5.31).

Assim como, no caso das nanopartículas sintetizadas em presença de SDS, via ablação a laser, houve uma pequena diminuição da banda da NFX no pico de $278 \mathrm{~nm}$, a qual poderia estar relacionada com um pequeno efeito sombra. Já no caso da banda plasmônica não houve modificação.

Os espectros de fluorescência da NFX, obtidos imediatamente após registrar cada espectro UV-Vis, são apresentados na Fig. 5.34, após a correção de efeito filtro. Podemos observar um aumento da fluorescência com deslocamento hipsocrômico do pico, em função do tempo, como observado com os AuNCs sintetizados em SDS. No entanto, as variações foram muito menores. A Tabela 2 mostra resumidamente as comparações entre os resultados. 

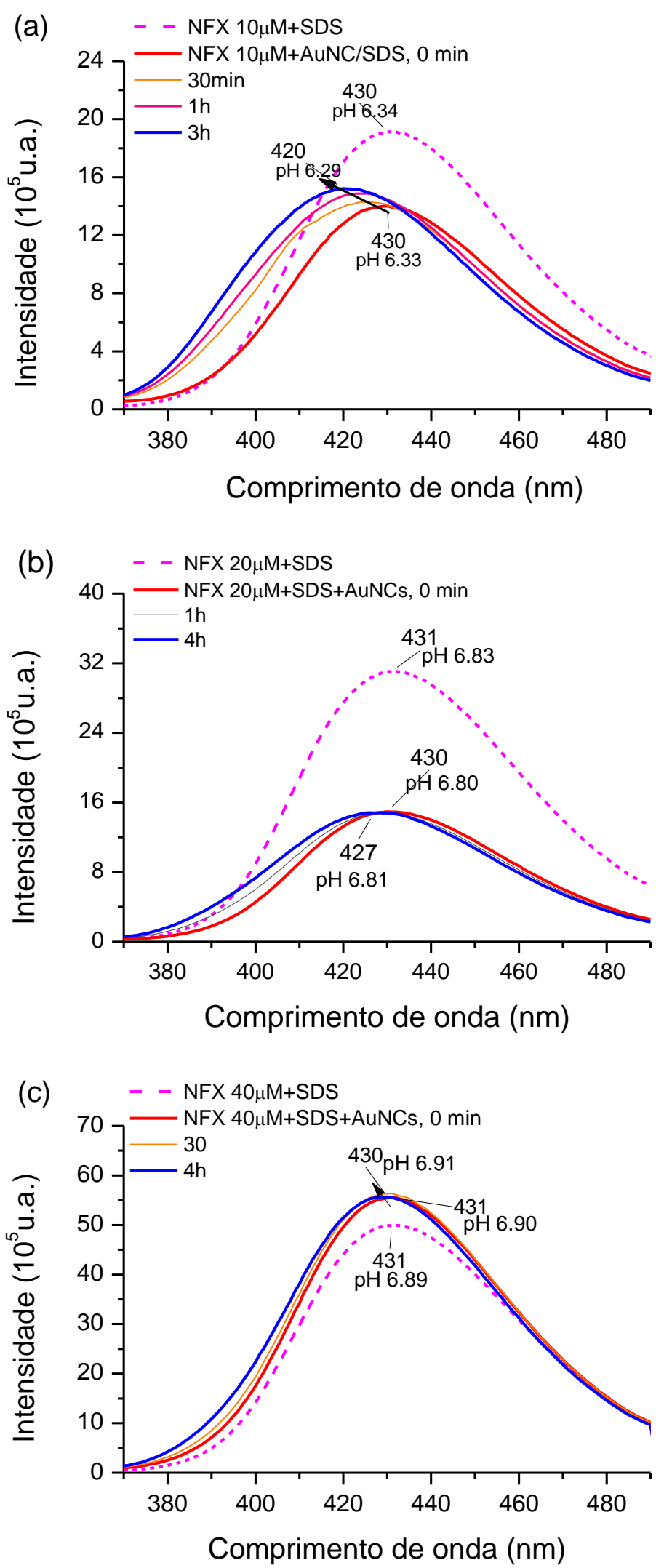

Figura 5.34. Espectros de fluorescência corrigidos de NFX 10 (a), 20 (b) e $40 \mu \mathrm{M}$ (c) em AuNCs adicionando SDS $10 \mathrm{mM}$ após ablação, para cada instante de tempo. Excitação em $330 \mathrm{~nm}$. 
Tabela 2. Comparação das mudanças na fluorescência da NFX em AuNC-SDS e em AuNC+SDS.

\begin{tabular}{ccc|cc}
\hline & \multicolumn{2}{c|}{ Incremento da Fluorescência } & \multicolumn{2}{c}{ Deslocamento hipsocrômico } \\
\hline $\begin{array}{c}\text { Concentração } \\
\text { de NFX em 4h } \\
(\mu \mathrm{M})\end{array}$ & $\begin{array}{c}\text { AuNCs } \\
\text { sintetizados } \\
\text { em SDS }(\%)\end{array}$ & $\begin{array}{c}\text { SDS } \\
\text { adicionado } \\
\text { aos AuNCs } \\
(\%)\end{array}$ & $\begin{array}{c}\text { AuNCs } \\
\text { sintetizados } \\
\text { em SDS (nm) }\end{array}$ & $\begin{array}{c}\text { SDS } \\
\text { adicionado } \\
\text { aos AuNCs } \\
(\mathrm{nm})\end{array}$ \\
\hline 10 & 32,8 & 17,3 & 13 & 10 \\
20 & 17,9 & 6,3 & 6 & 3 \\
40 & 13,8 & 3,4 & 5 & 1 \\
\hline
\end{tabular}

Todos estes resultados mostram que ambas interações de NFX com AuNCs sintetizados em SDS e com os AuNCs após adição de SDS não provocam agregação dos nanocompósitos. As mudanças nos espectros de extinção são desprezíveis em todos os casos, apenas presenta um pequeno efeito sombra.

As mudanças na fluorescência são mais notórias nas concentrações menores de NFX, tanto por adição direta do surfactante como ao usar SDS na síntese dos AuNCs. O incremento do rendimento quântico pode ser justificado pela proximidade da NFX à superfície dos nanocompósitos. Vemos na Tabela 2 que a interação da NFX com os AuNC-SDS é maior do que o caso dos AuNC+SDS. 


\section{Conclusão e perspectivas}

A formação dos complexos ternários mistos de $\mathrm{Cu}$ :Bipy e $\mathrm{Cu}$ :Phen com NFX foi estudada em micelas aniônicas de SDS usando absorção e fluorescência. Para NFX associada às micelas, as constantes de ligação com os complexos $\mathrm{Cu}$ :Bipy e $\mathrm{Cu}:$ Phen foram obtidas por supressão da fluorescência do fármaco, sendo estas constantes cerca de 50 vezes maiores do que em ausência de micelas. Portanto vemos que as micelas aniônicas de SDS favorecem a interação do complexo binário $\mathrm{Cu}$ :Bipy e Cu:Phen com NFX.

A espectroscopia de RPE mostrou que a interação observada entre os complexos binários e a NFX é resultado de formação do complexo ternário dentro das micelas de SDS, sendo estes complexos do tipo mononucleares, com parâmetros de RPE característicos de centro paramagnético com simetria axial, e com valores que indicam a presença de 2 átomos de nitrogênio e 2 de oxigênio coordenados ao íon cobre.

Portanto, vemos que as interfaces das membranas aniônicas alteram a estrutura e aumentam a estabilidade dos complexos de cobre com o fármaco fluorescente. A espectroscopia de RPE foi uma ferramenta valiosa para fornecer detalhes das variações estruturais das diferentes espécies paramagnéticas ligadas a esse modelo de membranas.

No caso de interação de NFX com vesículas de PC, o estudo espectroscópico mediante fluorescência mostrou interação do complexo binário com a NFX. A constante de associação obtida foi aproximadamente 80 vezes menor do que a obtida no estudo com micelas de SDS, mostrando uma menor influência na formação do complexo. Portanto, o modelo mais realístico de SUVs, em comparação às micelas de SDS, indica interação do complexo binário com a NFX dentro das SUVs, sendo esta associação muito menor do que a encontrada nas micelas. 
Nas experiências com a adição de cargas negativas do ânion de ácido esteárico à superfície das SUVs, quando maior era a proporção utilizada, menor era a supressão de fluorescência, sugerindo alguma blindagem na interação. Já com a adição de SDS para variar a carga negativa superficial de SUVs, a supressão aumentou à medida que a proporção de SDS era maior, mostrando constantes de associação levemente maiores do que as obtidas com SA.

A blindagem observada ao utilizar SA poderia ser explicada da seguinte forma: como a molécula de SA têm uma longa cadeia de carbonos (18), em comparação ao SDS (12 carbonos), é provável que por esta razão a incorporação do SA nas SUVs deixe mais rígidas as membranas, dificultando assim a difusão do complexo binário dentro das SUVs, diminuindo a supressão da fluorescência ao aumentar a proporção de SA.

Portanto, utilizando este procedimento de preparação de lipossomas mistos de PC com SDS ou ácido esteárico, verificamos que as SUVs favorecem também a interação do complexo binário com NFX quando utilizamos SDS e dificulta a interação ao usarmos SA, embora os dois sejam aniônicos e a interação comparada às micelas de SDS seja muito menor. Como perspectiva, pela complexidade das vesículas, deve-se estudar profundamente esta interação do complexo binário com a NFX dentro das SUVs, verificar com outras técnicas se ocorreu a formação do complexo ternário ou apenas estão muito próximos entre si o complexo binário e a NFX, e investigar melhor a difusão do complexo em SUVs carregadas negativamente com outras moléculas de diferentes tamanhos de cadeia de carbonos (influência da cauda hidrofóbica de moléculas aniônicas na incorporação às SUVs).

No trabalho com DNA, concluímos que a interação NFX-DNA não é afetada por forças eletrostáticas.

O trabalho com os nanocompósitos de ouro sintetizados via ablação a laser mostrou que os AuNCs em água ultrapura interagem fortemente com NFX, CFX e LFX, mostrando rápida aglomeração. Tratando os AuNCs com citrato 0,1 mM, essa agregação é lenta e ocorre em menor proporção. Dentre esses antibióticos, a NFX mostrou maior interação. As mudanças espectroscópicas, como deslocamento batocrômico e hipocromismo, assim como a supressão de fluorescência, sugerem mudança no índice de refração na superfície dos AuNCs, indicando associação com o fármaco e/ou formação de aglomerados. 
A glutationa, que contém um grupo tiol, liga-se fortemente à superfície dos AuNCs, portanto desloca moléculas de NFX associadas aos AuNCs, o que foi observado pelo incremento da fluorescência. Foi também possível verificar a reversibilidade das ligações AuNCs-NFX mediante diálise contra citrato, eliminando toda a contribuição de NFX na solução após diálise, indicando separação completa do fármaco dos nanocompósitos.

No estudo das nanopartículas sintetizadas por via química em CTAB, em pH baixo elas não interagem com NFX por ambas se encontrarem em estado catiônico (repulsão eletrostática). Quando tamponamos as amostras em pH fisiológico $(7,4)$ se observam consideráveis mudanças tanto na absorbância como na fluorescência, mostrando um incremento do rendimento quântico (provável transferência de energia devido ao efeito SPR, afetando as NFX muito próximas às AuNP-CTAB), assim como formação de aglomerados. Portanto, quando a NFX se torna zwitteriônica interage fortemente com as AuNP-CTAB.

Aproveitando a afinidade do SDS com NFX e a estabilidade de AuNCs em soluções desse surfactante, estudamos a interação de NFX com AuNCs-SDS e, por comparação, de NFX com AuNC+SDS, mostrando menor interação. A interação de NFX com AuNCs-SDS não provoca agregação das mesmas. O deslocamento do pico de fluorescência mostrou que NFX pode estar passando de um ambiente puramente micelar para a superfície dos AuNCs, sofrendo um deslocamento em sentido oposto ao observado ao ligar-se a micelas de SDS. O pequeno incremento na fluorescência sugere associação da NFX à superfície dos AuNCs/SDS (efeito SPR, afetando as NFX muito próximas à superfície dos AuNCs-SDS), sendo mais notório nas concentrações menores de NFX.

Estudos futuros de interação de FQs com AuNCs poderiam ser realizados profundamente, utilizando as técnicas de caracterização (HRTEM, espalhamento dinâmico de luz DLS, etc) depois de adicionar as FQs aos AuNCs e suas variantes. 


\section{Referências bibliográficas}

Abd El-Halim, H. F.; Mohamed, G. G.; El-Dessouky, M. M. I.; Mahmoud, W. H. Ligational behaviour of lomefloxacin drug towards $\mathrm{Cr}$ (III), $\mathrm{Mn}(\mathrm{II}), \mathrm{Fe}(\mathrm{III})$, $\mathrm{Co}(\mathrm{II}), \mathrm{Ni}(\mathrm{II}), \mathrm{Cu}(\mathrm{II}), \mathrm{Zn}(\mathrm{II}), \mathrm{Th}(\mathrm{IV})$ and $\mathrm{UO}_{2}$ (VI) ions: Synthesis, structural characterization and biological activity studies. Spectrochim. Acta A 82, 8-19, 2011.

Ahmed, A.; Daneshtalab, M. Nonclassical Biological Activities of Quinolone Derivatives. J. Pharm. Pharmaceut. Sci. 15, 52-72, 2012.

Amendola, V.; Meneghetti, M. Laser ablation synthesis in solution and size manipulation of noble metal nanoparticles. Phys. Chem. Chem. Phys. 11, 380521, 2009.

Amendola, V. Polizzi, S.; Meneghetti, M. Laser ablation synthesis of Gold Nanoparticles in Organic Solvents. J. Phys. Chem. B. 110(14), 7232-7237, 2006.

Amjadi, M.; Farzampour, L. Fluorescence quenching of fluoroquinolones by gold nanoparticles with different sizes and its analytical application. Journal of luminescence 145, 263-268, 2013.

Appelbaum, P. C.; Hunter, P. A. The fluoroquinolone antibacterials: Past, present and future perspectives. Int. J. Antimicrob. Agents 16, 5-15, 2000.

Baffa, Filho O. Estudos estruturais das mioglobinas de "Aplysia Brasiliana" e "Dermochelis Coriacea " por técnicas ópticas e ressonância paramagnética eletrônica. 1984. Tese de Doutorado, Instituto de Física e Química de São Carlos, Universidade de São Paulo, 1984.

Barbosa „J.; Fonrodona, G.; Marqués, I.; Sanz-Nebor, V.; Toro, I. Solvent effects on protonation equilibria of peptides and quinolonas by factors analysis applied to the correlation between dissociation constants and solvatochromic parameters in acetonitrile-water mixtures. Anal. Chim. Acta 3, 1, 397-405, 1997.

Barriviera, M. L.; Fontes, C. F. L.; Voloch, A. H.; Louro, S. R. W. Influence of nitric oxide donors on the intrinsic fluorescence ok $\mathrm{Na}+\mathrm{K}+-\mathrm{ATPase}$ and effects on the membrane lipids. Nitric Oxide Biology and Chemistry 13, 10-20, 2005.

Bonifácio, L. S. Processos de Agregação e Fusão de Nanopartículas de Ouro: Uma abordagem química. 2007. Dissertação de Mestrado em Química, Departamento de Química, Universidade de São Paulo, 2007.

Cassuto, J.; Sinclair, R.; Bonderovic, M. Anti-inflammatory properties of local anesthetics and their present and potential clinical implications. Acta Anaesthesiologica Scandinavica 50(3), 265-82, 2006. 
Chen, Y. M.; Cheng, T. L.; Tseng, W. L. Fluorescence turn-on detection of iodide, iodate and total iodine using fluorescein-5-isothiocyanate-modified gold nanoparticles. Analyst 134, 2106, 2009.

Cozzarelli, N. R. DNA gyrase and the supercoiling of DNA. Science 207, 953960, 1980.

Cuprys, A.; Pulicharla, R.; Brar, S. K.; Drogui, P.; Verma, M.; Surampalli, R. Y. Fluoroquinolones metal complexation and its environmental impacts. Coordination Chemistry Reviews 376, 46-61, 2018.

Darbha, G. K.; Ray, A.; Ray, P. C. Gold Nanoparticle- Based Miniaturized Nanomaterial Surface Energy Transfer Probe for Rapid and Ultrasensitive Detection of Mercury in Soil, Water, and Fish. ACS Nano Vol. 1, No. 3, 208214, 2007. Doi:10.1021/nn7001954.

Del Rosso, T.; Rey, N. A.; Rosado, T.; Landi, S.; Larrude, D. G.; Romani, E. C.; Freire Junior, F. L.; Quinteiro, S. M.; Cremona, M.; Aucelio, R. Q.; Margheri, G.; Pandoli, O. Synthesis of oxocarbon-encapsulated gold nanoparicles with blueshifted localized surface plasmon resonance by pulsed laser ablation in water with $\mathrm{CO}_{2}$ absorbers. Nanotechnology 27, 255602, 2016.

Del Rosso, T.; Louro, S. R. W.; Deepak, F. L.; Romani, E. C.; Zaman, Q; Tahir; Pandoli, O.; Cremona, M.; Freire Junior, F. L.; De Buele, P.; De St. Pierre, T.; Aucelio, R. Q.; Mariotto, G.; Gemini-Piperni, S.; Ribeiro, A. R.; Landi, S. M.; Magalhães, A. Biocompatible Au@Carbynoid/Pluronic-F127 nanocomposites synthesized by pulsed laser ablation assisted CO2 recycling. Applied Surface Science 441, 347-355, 2018.

Drakopoulos, A. I.; Ioannou, P. C. Spectrofluorimetric study of the acid-base equilibria and complexation behavior of the fluoroquinolone antibiotics ofloxacin, norfloxacin, ciprofloxacin and pefloxacin in aqueous solution. Analytica Chimica Acta 354, 197-204, 1997.

Drevenšek, P.; Turel, I.; Poklar, Ulrih, N. Influence of copper (II) and magnesium (II) ions on the ciprofloxacin binding to DNA. J. Inorg. Biochem. 96, 407-415, 2003.

Duzgunes, N.; Flasher, D.; Ready, M. V.; Luna Herrera, J.; Gangadharam, P. R. J. Treatment of intracellular Mycobacterium avium complex infection by free and liposome-encapsulated Sparfloxacin. Antimicr. Agents Chemother. 40, 2618, 1996.

Esponda, S. M.; Padrón, E. T.; Ferrea, Z. S.; Rodriguez, J. J. S. Solid-phase microextraction with micellar desorption and HPLc-fluorescence detection for the analysis of fluorquinolones residues in water samples. Anal. Bional. Chem. 394, 927-935, 2009.

Fedlheim, D. L.; Foss, C. A. Metal Nanoparticles-Synthesis, Characterization, and Applications. CRC press, New York, USA, 2001.

Firdaus, F.; Fatma, K.; Azam, M.; Khan, S. N.; Khan, A. U.; Shakir, M. Template synthesis and physicochemical studies of 14-membered hexaazmacrocyclic complexes with $\mathrm{Co}(\mathrm{II}), \mathrm{Ni}(\mathrm{II}), \mathrm{Cu}(\mathrm{II})$ and $\mathrm{Zn}$ (II): a comparative spectroscopic approach on DNA binding with $\mathrm{Cu}(\mathrm{II})$ and Ni(II) complexes. Transition Metal Chemistry 33, 467-473, 2008. 
Food Biopolymers and Colloids Research Laboratory. Disponível em: http://people.umass.edu/mcclemen/Group.html, Acesso em: 27 jun. 2018.

Fong, Y. Y.; Gascooke, J. R.; Visser, B. R.; Metha, G. F.; Buntine, M. A. Laserbased formation and properties of gold nanoparticles in aqueous solution: formation kinetics and surfactant-modified particle size distributions. The Journal of Physical Chemistry C. 114(38), 15931-15940, 2010.

Gao, F.; Ye, Q.; Cui, P.; Chen, X.; Li, M.; Wang, L. Selective "turn-on" fluorescent sensing for biothiols based on fluorescence resonance energy transfer between acridine orange and gold nanoparticles. Anal. Meth. 3, 1180$1185,2011$.

Ghosh, D.; Girigoswami, A.; Chattopadhyay, N. Superquenching of coumarin 153 by gold nanoparticles. J. Photochem. Photobiol. A: Chem. 242, 44, 2012.

Góes, F. L. da Silva. Caracterização e estudos cinéticos de albumina tratada com espécies reativas derivadas de óxidos de nitrogênio: espectroscopia de absorção e fluorescência. 2005. 84p. Dissertação de Mestrado em Física, Pontifícia Universidade Católica do Rio de Janeiro, Rio de Janeiro, 2005.

Gordon, M. B. Physical Chemistry. Fourth edition. McGraw-Hill Book Company, 1984.

Grace, N. A.; Pandian, K. Quinolone Antibiotic-Capped Gold Nanoparticles and their Antibacterial Efficacy Against Gram Positive and Gram Negative Organisms. Journal of Bionanoscience 1, 96-105, 2007.

Griffin, J.; Singh, A. K.; Senapati, D.; Rhodes, P.; Mitchell, K.; Robinson, B.; Yu, E.; Ray, P. C. Size- and distance-dependent nanoparticle surface-energy transfer (NSET) method for selective sensing of hepatitis C virus RNA. Chemistry a European Journal 15(2), 342-351, 2009.

Gu, H.; Ho, P. L.; Tong, E.; Wang, L.; Xu, B. Presenting Vancomycin on Nanoparticles to Enhance Antimicrobial Activities. Nano Lett. 3, 1261, 2003.

Guo, L.; Zhong, J.; Wu, J.; Fu, F.; Chen, G.; Chen, Y.; Zheng, X.; Lin, S. Sensitive turn-on fluorescent detection of melamine based on fluorescence resonance energy transfer. Analyst 136, 1659, 2011.

Guo, D.-S.; Jing, B. Y.; Yuan, X.-Y. Influence of $\mathrm{Mg}^{2+}$ and $\mathrm{Cu}^{2+}$ on the interaction between quinolone and calf thymus DNA. J. Fluoresc. 21, 113-118, 2011.

Herold, C.; Ocker, M.; Ganslmayer, M.; Gerauer, H.; Hahn, E. G.; Schuppan, D. Ciprofloxacin induces apoptosis and inhibits proliferation of human colorectal carcinoma cells. Br. J. Cancer. 86, 443-448, 2002.

Hooper, D. C. Clinical applications of quinolones. Biochim. Biophys. Acta. 1400, 45-61, 1998.

Hooper, D. C. Mechanisms of action and resistance of older and newer fluoroquinolones. Clin. Infect. Dis. 31, S24-S28, 2000.

Hormozi-Nezhad, M. R.; Bagheri, H.; Bohloul, A.; Taheri, N.; Robatjazi, H. Highly sensitive turn-on fluorescent detection of captopril based on energy transfer between fluorescein isothiocyanate and gold nanoparticles. J. Lumin. 134, 874, 2013. 
Huang, W. C.; Tsai, P. J.; Chen Y. C. Functional gold nanoparticles as photothermal agents for selective-killing of pathogenic bacteria. Nanomedicine 2, 777, 2007.

Jain, P. R.; Huang, X.; El-Sayed, I. H.; El-Sayed, M. A. Noble Metals on the Nanoscale: Optical and Photothermal Properties and Some Applications in Imaging, Sensing, Biology, and Medicine. Acc. Chem. Res. 41, 1578, 2008.

Jayabharathi, J.; Thanikachalam, V.; Sathishkumar, R.; Jayamoorthyet, K. Fluorescence investigation of the interaction of 2-(4-fluorophenyl)-1-phenyl1H-phenanthro[9,10-d] imidazole with bovine serum albumin. Journal of Photochemistry and Photobiology B: Biology 117, 222-227, 2012.

Jennings, T. L.; Schlatterer, J. C.; Singh, M. P.; Greenbaum, N. L.; Strouse, G. F. NSET molecular beacon analysis of hammerhead RNA substrate binding and catalysis. Nano Lett. 6, 1318, 2006.

Jennings, T. L.; Singh, M. P.; Strouse, G. F. J. Fluorescent lifetime quenching near $\mathbf{d}=1.5 \mathrm{~nm}$ gold nanoparticles: probing NSET validity. Am. Chem. Soc. 128, 5462, 2006.

Kamat, B. P. Study of the interaction between fluoroquinolones and bovine serum albumin. Journal of Pharmaceutical and Biomedical Analysis 39, 10461050, 2005.

King, D. E.; Malone, R.; Lilley, S. H. New classification and update on the quinolone antibiotics. Am. Fam. Phys. 61, 2741-1748, 2000.

Koletar, S. L. Treatment of Mycrobacterium avium in human immunodeficiency virus infected individuals. Am. J. Med. 102, 16, 1997.

Köpf-Maier. Complexes of metals other than platinum as antitumour agents. Eur. J. Pharmacol. 47, 1-16, 1994.

Kutchai, H.; Geddis, L. M. Inhibition of the Na,K-ATPASE of canine renal medulla by several local anesthetics. Pharmacological Research. 43 (4), 399-403, 2001.

Lakovicz, J. R. Principles of fluorescence spectroscopy. Third Edition. Springer 2006.

Lee, A. G. Model for action of local anaesthetics. Nature 262, 545-548, 1976.

Lesher, G. Y.; Froelich, E. J.; Gruett, M. D.; Bailey, J. H.; Brundage, R. P. 1,8Naphthyridine derivatives: a new class of chemotherapeutic agents. Journal of Medicinal Pharmaceutical Chemistry 5, 1063-1065, 1962.

Majumdar, S.; Flasher, D.; Friend, D. S.; Nassos, P.; Yajko, D.; Hadley, W. K.; Duzgunes, N. Efficacies of liposome-encapsulated Streptomycin and Ciprofloxacin against Mycobacterium avium-M. Intracellulare complex infections in human peripheral blood monocyte macrophages. Antimicr. Agents Chemother. 36, 2808, 1992.

Maxwell, A. The molecular basis of quinolone action. J. Antimicrob. Chemother. 30, 409-414, 1992.

Mitscher, L. A. Bacterial topoisomerase inhibitors: Quinolone and pyridone antibacterial agents. Chem. Rev. 105, 559-592, 2005. 
Möhler, J. S.; Kolmar, T.; Synnatschke, K.; Hergert, M.; Wilson, L. A.; Ramu, S.; Elliott A. G.; Blaskovich, M. A. T.; Sidjabat, H. E.; Paterson, D. L.; Schenk, G.; Cooper, M. A.; Ziora, Z. M. Enhancement of antibiotic-activity through complexation with metal ions - Combined ITC, NMR, enzymatic and biological studies. Journal of Inorganic Biochemistry 167, 134-14, 2017.

Muniz, G. S. V. Estudos da interação do antibiótico norfloxacina e de seus complexos de cobre com micelas de surfactantes iônicos por espectroscopia de absorção UV-visível e fluorescência. 2013. Dissertação de Mestrado em Física, Pontifícia Universidade Católica do Rio de Janeiro, Rio de Janeiro, 2013.

Muniz, G. S. V.; Louro, S. R. W.; Teixeira, L. R. Interaction of the antibiotic norfloxacin with ionic micelles: pH-dependent binding. Eur Biophy J. 43, 477483, 2014.

Muniz, G. S. V.; Incio, J. L.; Alves, O. C.; Krambock, K.; Teixeira, L. R.; Louro, S. R. W. Norfloxacin and $\mathbf{N}$-donor mixed-ligand copper(II) complexes: fluorescence and EPR studies of stability and influence of SDS micelles in complex formation. Spectrochim. Acta A Mol. Biomol. Spectrosc. 189, 133-138, 2017.

Nagata, L. P.; Wong, J. P.; Saravolar, E. G. Use of liposome encapsulated Ciprofloxacin as an immunotherapeutic drug. Canada Minister Defense, patente $n^{\circ} \mathrm{CA} 1996217480319960423,1999$.

Ohki, S. Adsorption of Local Anesthetics on Phospholipid Membranes. Biochimica et Biophysica Acta 777, 56-66, 1984.

Oliphant, C. M.; Green, G. M. Quinolones: A comprehensive review. Am. Fam. Phys. 65, 455-464, 2002.

O'Neil, M. J. The Merck Index: an encyclopedia of chemicals, drugs and biologicals. $14^{\text {th }}$. Whitehouse Station: Merck, 2006.

Palazzo, G.; Valenza, G.; Dell' Aglio, M.; De Giacomo, A. On the stability of gold nanoparticles synthesized by laser ablation in liquids. Journal of Colloid and interface Science 489, 47-56, 2017.

Paraginski, G. L. Triazenos: Clivagem do DNA, atividade antibacteriana e toxicidade frente à Artemia salina LEACH. 2007. Dissertação de Mestrado em Ciências Farmacêuticas, Universidade Federal de Santa Maria, Rio Grande do Sul, 2007.

Patel, M. N.; Patidar, A. P. DNA interaction and promotion in antibacterial activities of norfloxacin drug due to formation of mixed-ligand copper(II) complexes. Monatshefte für Chemie - Chemical Monthly 145, 369-381; 2014.

Peisach, J.; Blumberg, W. E. Structural implications derived from the analysis of electronparamagnetic resonance spectra of natural and artificial copper proteins. Arch. Biochem. Biophys. 165, 691-708, 1974.

Pissuwan, D.; Valenzuela, S. M.; Miller, C. M.; Cortie, M. B. A Golden Bullet? Selective Targeting of Toxoplasma gondii Tachyzoites Using AntibodyFunctionalized Gold Nanorods. Nano Lett. 7, 3808, 2007.

Psomas, G.; Kessissoglou, D. P. Quinolones and non-steroidal antiinflammatory drugs interacting with copper(II), nickel(II), cobalt(II) and zinc(II): Structural 
features, biological evaluation and perspectives. Dalton Trans. 42, 6252-6276, 2013.

Ragsdale, D. S.; Mcphee, J. C.; Scheuer, T.; Catterall, W. A. Molecular determinants of state dependent block of $\mathrm{Na}+$ channels by local anesthetics. Science 265, 1724-1728, 1994.

Ray, P. C.; Fortner, A.; Darbha, G. K. Gold nanoparticle based FRET assay for the detection of DNA cleavage. J. Phys. Chem. B 110, 20745, 2006.

Reichmann, M. E.; Rice, S. A.; Thomas, C. A.; Paul Doty. A Further Examination of the Molecular Weight and Size of Desoxypentose Nucleic Acid. J. Am. Chem. Soc. 76, 3047-3053, 1954.

Robles, J.; Martin-Polo, J.; Avarez-Valtierra, L.; Hinojosa, L.; Mendoza-Diaz, G. A theoretical-experimental study on the structure and activity of certain quinolones and the interaction of their $\mathrm{Cu}(\mathrm{II})$-complexes on a DNA model. Met. Based Drugs. 7, 301-311, 2000.

Romero, O. M. P. Estudo da interação de fotossensibilizantes derivados de ftalocianinas com sistemas de distribuição de fármacos para terapia fotodinâmica. 2012. Tese de Doutorado em Física, PUC-Rio, 2012.

Rosemary, M. J.; MacLaren, I.; Pradeep, T. Investigations of the Antibacterial Properties of Ciprofloxacin@SiO2. Langmuir 22, 10125, 2006.

Sakaguchi, M.; Kuroda, Y.; Hirose, M. The antiproliferative effect of lidocaine on human tongue câncer cells with inhibition of the activity of epidermal growth factor receptor. International Anesthesia Research Society 102, 11031107, 2006.

Sacheteli, S.; Khalil, H.; Chen, T.; Beaulac, C.; Sénechal, S.; Lagacé, J. Demonstration of a fusion mechanism between a fluid bactericidal liposomal formulation and bacterial cells. Biochem. Biophys. Acta 1463, 254, 2000.

Shah, S. S.; Jamroz, N. U.; Sharif, Q. M. Micellization parameters and electrostatic interactions in micellar solution of sodium dodecyl sulfate (SDS) at different temperatures. Colloids Surf. A Physicochem. Eng. Asp. 178, 199206, 2001.

Sissi, C.; Palumbo, M. The quinolone family: From antibacterial to anticancer agents. Curr. Med.Chem. Anticancer Agents 3, 439-450, 2003.

Song, G.; Yan, Q.; He, Y. Studies on interaction of norfloxacin, $\mathrm{Cu}^{2+}$ and DNA by spectral methods. J. Fluoresc. 15, 673-678, 2005.

Sultana, N.; Naz, A.; Arayne, M. S.; Ahmed, M. M. Synthesis, characterization, antibacterial, antifungal and immunomodulating activities of gatifloxacinmetal complexes. J. Mol. Struct. 969, 17-24, 2010.

Swartz, M. S.; Bolton, J. R.; Borg, D. C. Biological Applications of Electron spin resonance. Wiley-Interscience: New York, 1972.

Thadepalli, H.; Salem, F.; Chuah, S. K.; Gollapudi, S. Antitumor activity of trovafloxacin in an animal model. In Vivo 19, 269-276, 2005.

Turel, I.; Bukovec, N.; Farkas, E. Complex formation between some metals and a quinolone family member (ciprofloxacin). Polyhedron 15, 269-275, 1996. 
Turel, I.; Kljun, J.; Perdih, F.; Morozova, E.; Bakulev, V.; Kasyanenco, N.; Byl, J. A. W.; Osheroff, N. First ruthenium organometallic complex of antibacterial agent ofloxacin. Crystal structure and interactions with DNA. Inorg. Chem. 49, 10750-10752, 2010.

Turkel, N.; Sahin, Ç. Stability of binary and ternary copper(II) complexes with 1,10-phenanthroline, 2,2'-bipyridyl and some $\alpha$-amino acids in aqueous medium. Chem Pharm Bull. 57(7), 694-699, 2009.

Turkevich, J.; Garton, G.; Stevenson, P. C. The color of colloidal gold. Journal of colloid Science. 9, 26-35, 1954.

Uivarosi, V. Metal Complexes of Quinolone Antibiotics and Their applications: an Update. Molecules 18, 11153-11197, 2013. Doi:10.3390/molecules180911153.

Valeur, B. Molecular Fluorescence: Principles and Applications. Wiley-VCH Verlag GmbH, 2001. ISBNS: 3-527-299919X.

Vries, H.; Henegouwen, G. M. J. B. Photochemical descomposition of Lomefloxacin in vitro and in vivo. J. Photochem. Photobiol. B: Biol. 58, 6, 2000.

Weil, J. A.; Bolton, J. R.; Wertz, J. E. Electron Paramagnetic Resonance Elementary Theory and Practical Applications. John Wiley \& Sons, Inc, 1994.

Williams, D. N.; Ehrman, S. H.; Holoman, T. R. P. Evaluation of the microbial growth response to inorganic nanoparticles. J. Nanobiotechnol. 4, Art. No. 3, 2006.

Yun, C. S.; Javier, A.; Jennings, T.; Fisher, M.; Hira, S.; Peterson, S.; Hopkins, B.; Reich, N. O.; Strouse, G. F. Nanometal surface energy transfer in optical rulers, breaking the FRET barrier. J. Am. Chem. Soc. 127, 3115, 2005.

Zhanel, G. G.; Walkty, A.; Vercaigne, L.; Karlowsk, J. A.; Embil, J.; Gin, A. S.; Hoban, D. J. The new fluoroquinolones: A critical review. Can. J. Infect. Dis. 10, 207-238, 1999.

Zhanguang, Ch.; Taiyu, Z.; Xiangming, Ch.; Yali, H.; Li, Z. Interactions of norfloxacin with DNA and determination of DNA at nanogram levels based on the measurement of enhanced resonance light scattering. Microchim. Acta 157, 107-112, 2007.

Zharov, V. P.; Mercer, K. E.; Galitovskaya, E. N.; Smeltzery, M. S. Photothermal nanotherapeutics and nanodiagnostics for selective killing of bacteria targeted with gold nanoparticles. Biophys. J. 90, 619, 2006. 